\begin{tabular}{|c|c|c|c|c|c|c|}
\hline \multirow{4}{*}{ Impact Factor: } & ISRA (India) & $=3.117$ & SIS (USA) & $=0.912$ & ICV (Poland) & $=6.630$ \\
\hline & ISI (Dubai, UAI & $=0.829$ & РИНЦ (Russia) & $=0.156$ & PIF (India) & $=1.940$ \\
\hline & GIF (Australia) & $=0.564$ & ESJI (KZ) & $=5.015$ & IBI (India) & $=4.260$ \\
\hline & JIF & $=1.500$ & SJIF (Morocco) & $=5.667$ & & \\
\hline
\end{tabular}

SOI: $\underline{1.1 / \mathrm{TAS}} \quad$ DOI: $10.15863 / \mathrm{TAS}$
International Scientific Journal
Theoretical \& Applied Science
p-ISSN: $2308-4944$ (print) $\quad$ e-ISSN: $2409-0085$ (online)
Year: $2018 \quad$ Issue: $12 \quad$ volume: 68
Published: $21.12 .2018 \quad \underline{\text { http://T-Science.org }}$

SECTION 7. Mechanics and machine construction.
QR - Issue

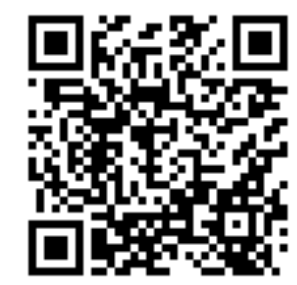

M.Sc.Eng Corresponding Member of International Academy of Theoretical and Applied Sciences, Lecturer of Vladimir Industrial College, Russian Federation https://orcid.org/0000-0002-2747-552X chemezov-da@yandex.ru

Alexandra Strunina Lecturer of Vladimir Industrial College, Russian Federation

Irina Medvedeva Master of Industrial Training, Vladimir Industrial College, Russian Federation

Irina Pavluhina Lecturer of Vladimir Industrial College, Russian Federation

Alexandr Korobkov Student of Vladimir Industrial College, Russian Federation

Evgeny Varavin Student of Vladimir Industrial College, Russian Federation

Tatyana Lukyanova Lecturer of Vladimir Industrial College, Russian Federation

\title{
COMPARATIVE ANALYSIS OF AN IMPELLER GEOMETRY AT DIFFERENT HEADS OF A PUMP
}

Abstract: Impellers designing with ten blades at different heads of a hydraulic pump (from 5 to $25 \mathrm{~m}$ ) by means of the Ansys Workbench software environment was carried out in the article. Three-dimensional models are presented and elements description of the radial impeller of the pump is given. Calculations of the impellers geometry were carried out at volume fluid flow rate (water) of $300 \mathrm{~m}^{3} / \mathrm{h}$. Profiles and geometric dimensions of the impeller blades are obtained in the spans: 0 and 1. It is determined that the radial impellers are recommended to be used at the pump head of $20-25 \mathrm{~m}$. The most stable characteristic of the pump operation is observed in this range of heads. Tangential, meridional and relative velocities of fluid flow at the impeller blades are calculated.

Key words: a radial impeller, a blade, a pump head, theta, beta, thickness, a shroud, a hub, fluid, a pump.

Language: English

Citation: Chemezov, D., et al. (2018). Comparative analysis of an impeller geometry at different heads of a pump. ISJ Theoretical \& Applied Science, 12 (68), 149-192.

Soi: $\underline{\text { http://s-o-i.org/1.1/TAS-12-68-27 Doi: crossef https://dx.doi.org/10.15863/TAS.2018.12.68.27 }}$

\section{Introduction}

Energy conversion of rotation of a motor shaft into fluid flow energy is performed by means of a radial impeller. Fluid moves from a center to a periphery of a device, i.e. centrifugal force occurs at rotation of the impeller. Vacuum is created in a central part of the radial impeller, which provides fluid supply under pressure to a suction pipe of the pump. The impellers are made of cast iron or steel.

Main elements of the radial impeller [1 - 10] are presented by the wire three-dimensional models in the Fig. $1-13$. In a shroud it is located a hub with blades (the impeller). A gap is provided between maximum outer diameters of the shroud and the 


\begin{tabular}{|c|c|c|c|c|c|c|}
\hline \multirow{4}{*}{ Impact Factor: } & ISRA (India) & $=3.117$ & SIS (USA) & $=0.912$ & ICV (Poland) & $=6.630$ \\
\hline & ISI (Dubai, UAI & $=0.829$ & РИНЦ (Russia) & $=0.156$ & PIF (India) & $=1.940$ \\
\hline & GIF (Australia) & $=0.564$ & ESJI (KZ) & $=5.015$ & IBI (India) & $=4.260$ \\
\hline & JIF & $=1.500$ & SJIF (Morocco) & $=5.667$ & & \\
\hline
\end{tabular}

impeller, which is an outlet for moving fluid. Fluid is pumped into an inlet. The minimum and maximum diameters of the inlet equal to the minimum diameter of the hub and the minimum inner diameter of the pump shroud. The impeller blade profile is presented by end surfaces of the blades at the hub and the shroud. A periodic boundary defines a contour of a calculated cavity, which is located between the hub and the shroud. A centroid divides a passage area of the impeller in half. Mean lines characterize a number of the meridional flow surfaces. The camber surface of the blade is characterized by a maximum ordinate of the mean line of the profile. This parameter depends on the inlet angle and the outlet angle of fluid. The inlet and outlet edges of the blade are rounded, and a value of a rounding radius should be selected taking into account the requirements of hydrodynamics. The throat surface is defined as a distance between the low theta side and the high theta side along the blade surface. The radial impeller is built in the BladeGen module of the Ansys Workbench software environment.
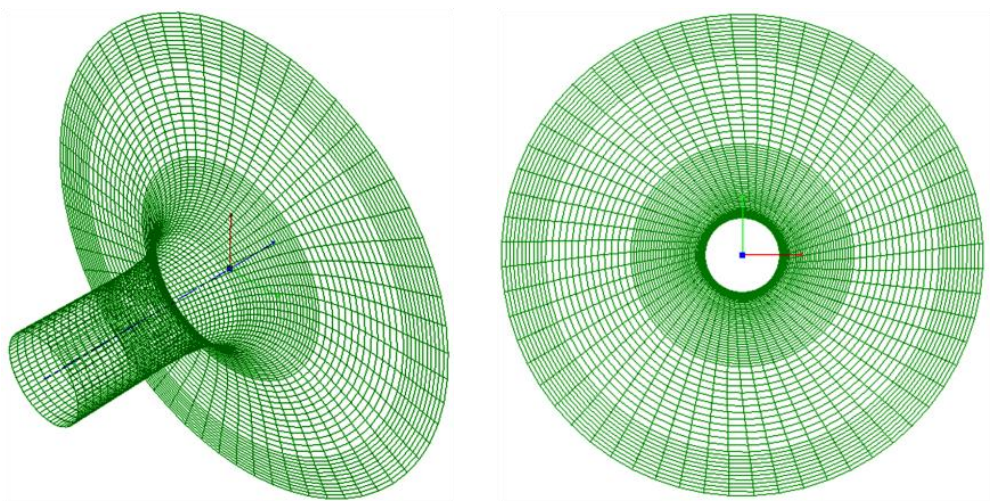

Figure 1 - The hub of the radial impeller.
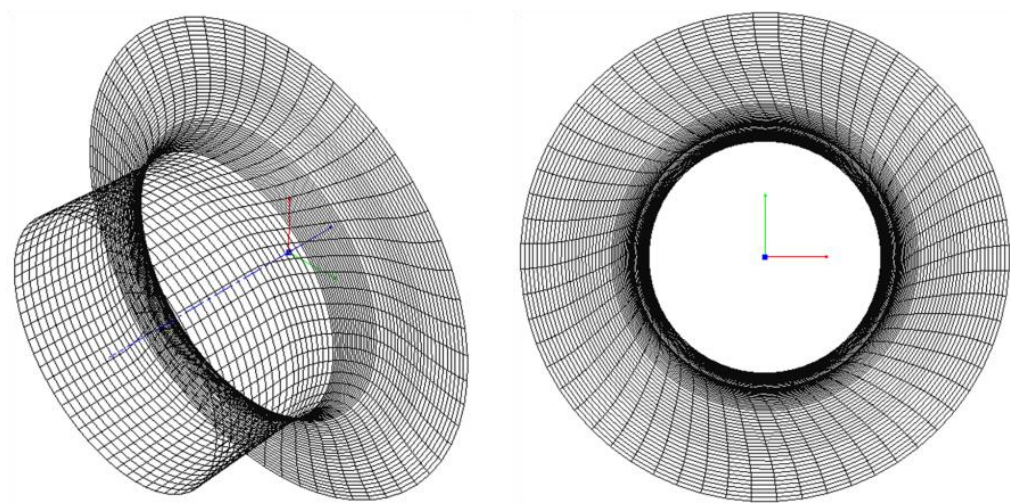

Figure 2 - The shroud of the radial impeller.
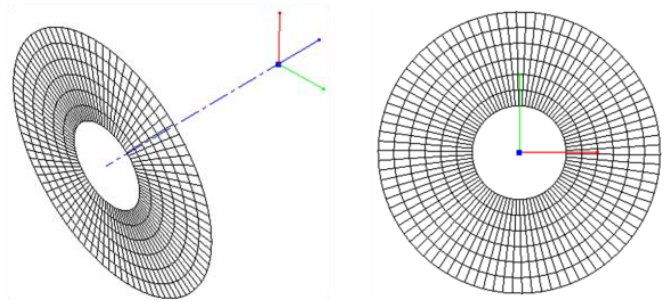

Figure 3 - The inlet of the radial impeller.
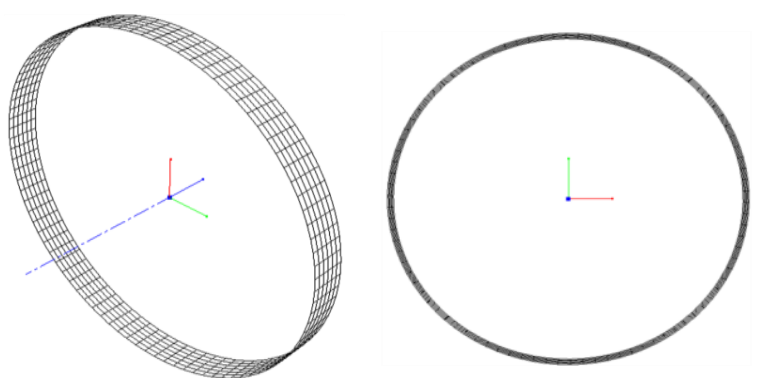

Figure 4 - The outlet of the radial impeller. 


\begin{tabular}{|c|c|c|c|c|c|c|}
\hline \multirow{4}{*}{ Impact Factor: } & ISRA (India) & $=3.117$ & SIS (USA) & $=0.912$ & ICV (Poland) & $=6.630$ \\
\hline & ISI (Dubai, UAE & $=0.829$ & РИНЦ (Russia) & $=0.156$ & PIF (India) & $=1.940$ \\
\hline & GIF (Australia) & $=0.564$ & ESJI (KZ) & $=\mathbf{5 . 0 1 5}$ & IBI (India) & $=4.260$ \\
\hline & JIF & $=1.500$ & SJIF (Morocco) & $=5.667$ & & \\
\hline
\end{tabular}
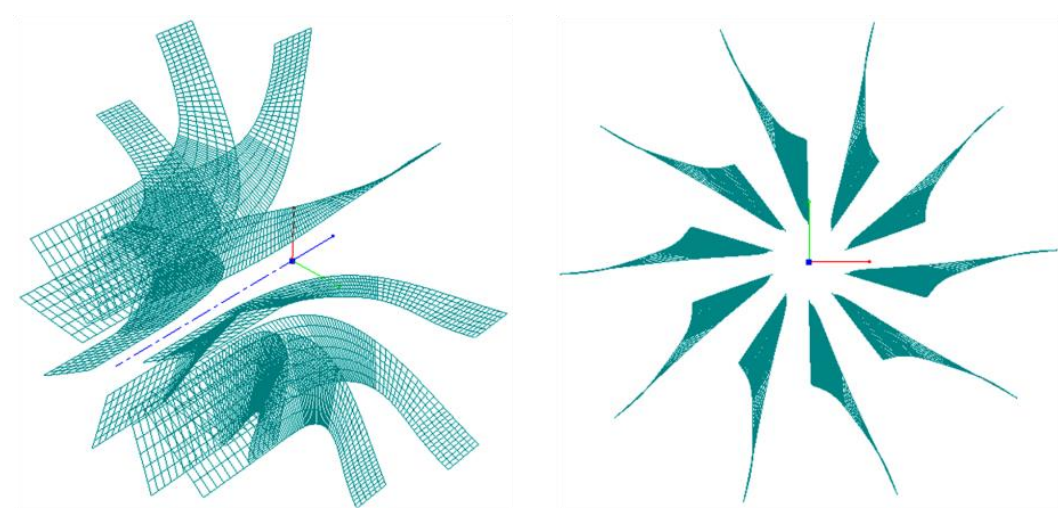

Figure 5 - The periodic of the radial impeller.
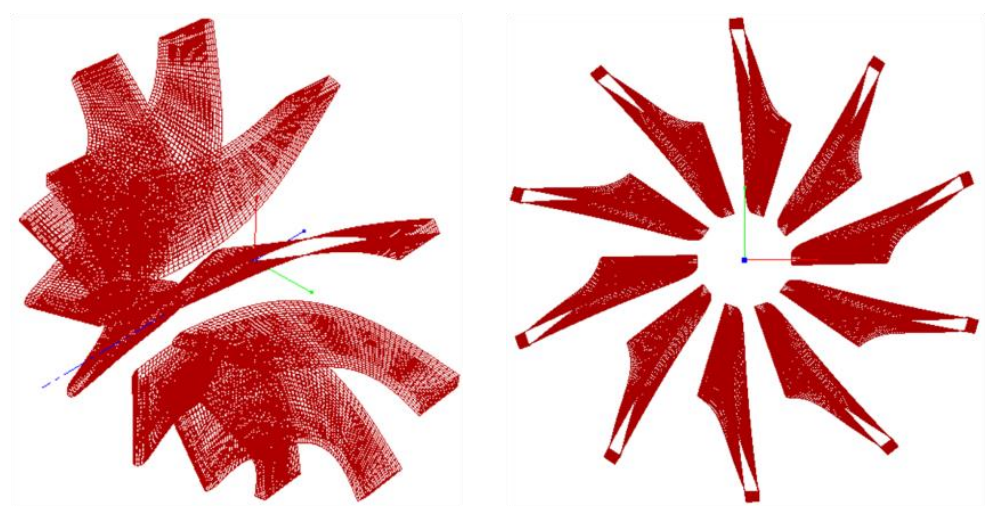

Figure 6 - The blades of the radial impeller.
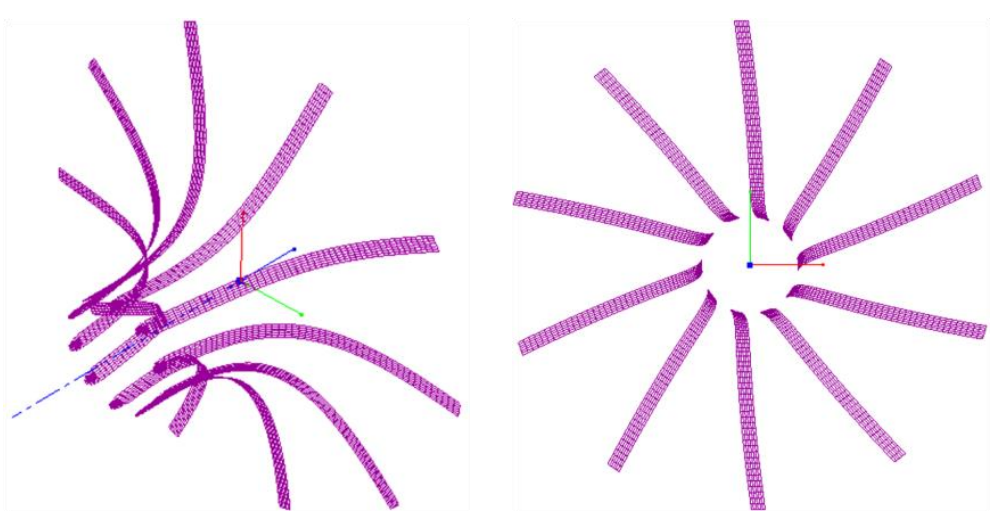

Figure 7 - The blades hub end of the radial impeller.

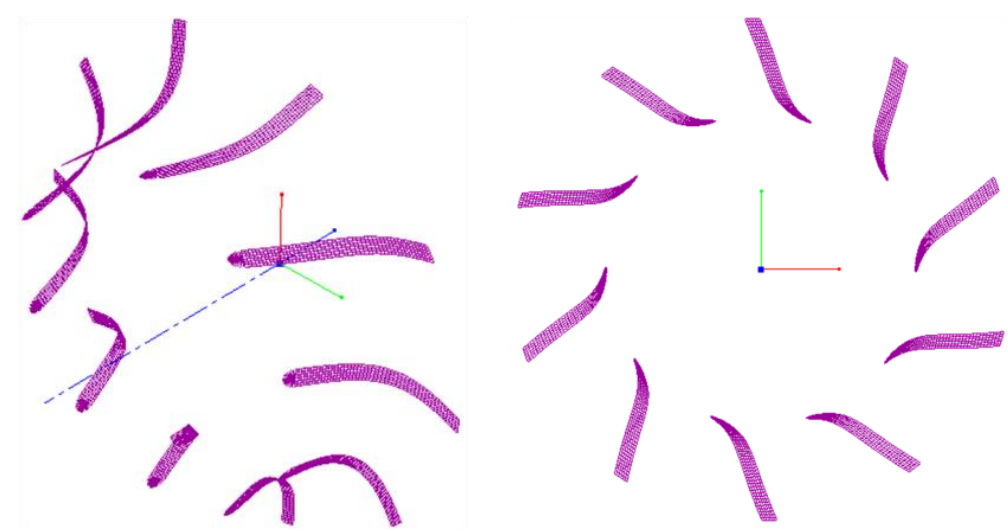

Figure 8 - The blades shroud end of the radial impeller. 


\begin{tabular}{lllllll} 
& ISRA (India) & $=\mathbf{3 . 1 1 7}$ & SIS (USA) & $=\mathbf{0 . 9 1 2}$ & ICV (Poland) & $\mathbf{= 6 . 6 3 0}$ \\
Impact Factor: & ISI (Dubai, UAE) $=\mathbf{0 . 8 2 9}$ & PUHL (Russia) $=\mathbf{0 . 1 5 6}$ & PIF (India) & $\mathbf{= 1 . 9 4 0}$ \\
& GIF (Australia) & $=\mathbf{0 . 5 6 4}$ & ESJI (KZ) & $=\mathbf{5 . 0 1 5}$ & IBI (India) & $\mathbf{4 . 2 6 0}$ \\
& JIF & $\mathbf{1 . 5 0 0}$ & SJIF (Morocco) & $=\mathbf{5 . 6 6 7}$ & & \\
\hline
\end{tabular}

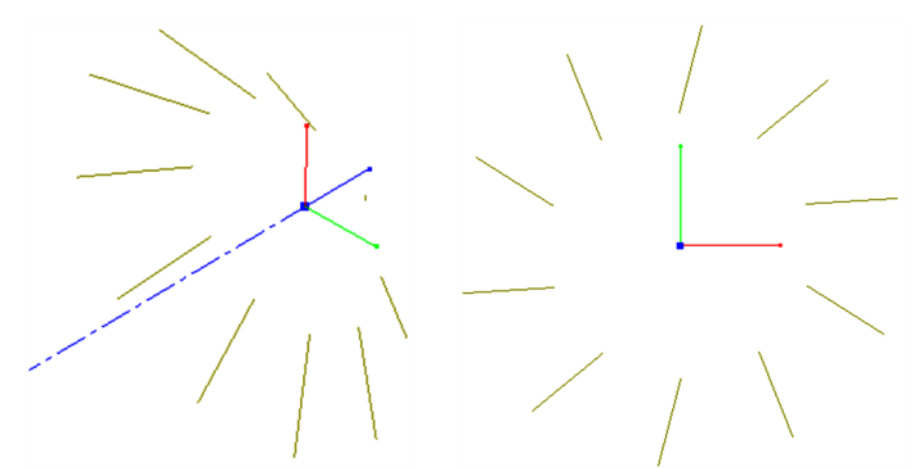

Figure 9 - The blades centroid of the radial impeller.
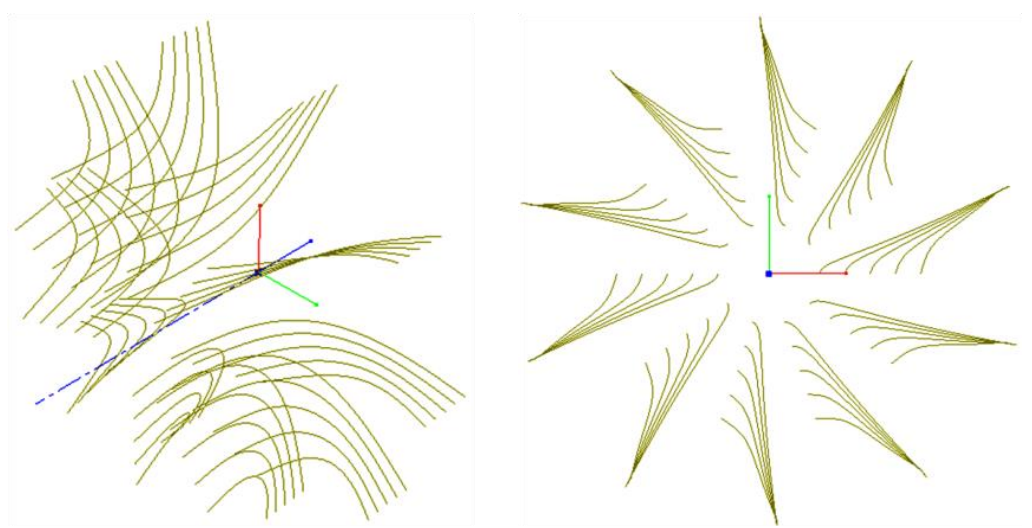

Figure 10 - The mean lines of the radial impeller.
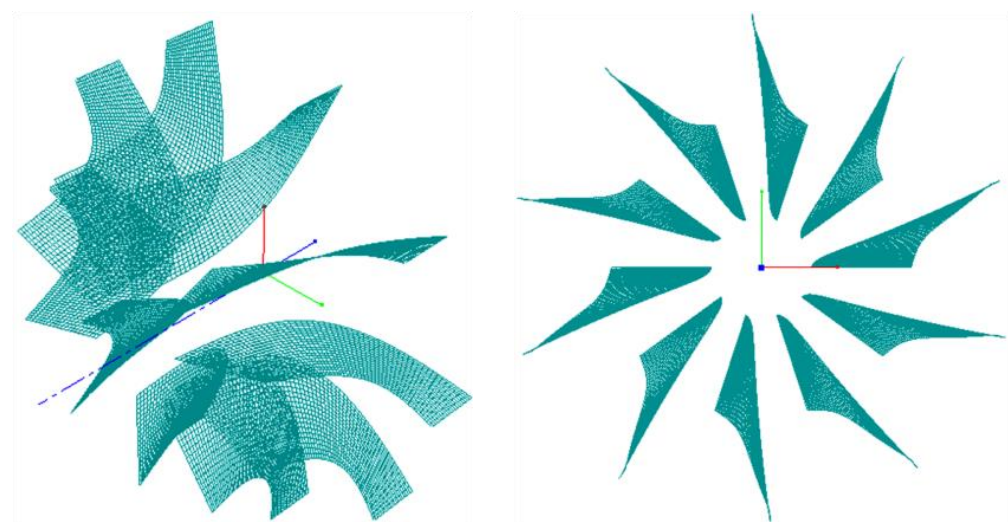

Figure 11 - The camber surfaces of the radial impeller.
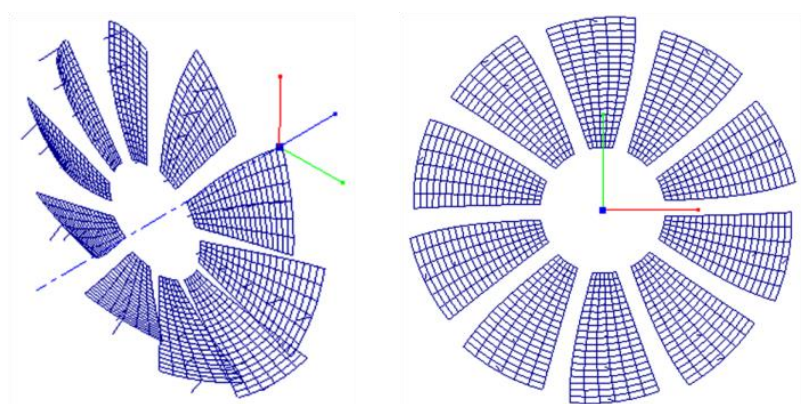

Figure 12 - The throat surfaces of the radial impeller. 


\begin{tabular}{|c|c|c|c|c|c|c|}
\hline \multirow{4}{*}{ Impact Factor: } & ISRA (India) & $=3.117$ & SIS (USA) & $=0.912$ & ICV (Poland) & $=6.630$ \\
\hline & ISI (Dubai, UAE & $=0.829$ & РИНЦ (Russia) & $=0.156$ & PIF (India) & $=1.940$ \\
\hline & GIF (Australia) & $=0.564$ & ESJI (KZ) & $=5.015$ & IBI (India) & $=4.260$ \\
\hline & JIF & $=1.500$ & SJIF (Morocco) & $=5.667$ & & \\
\hline
\end{tabular}
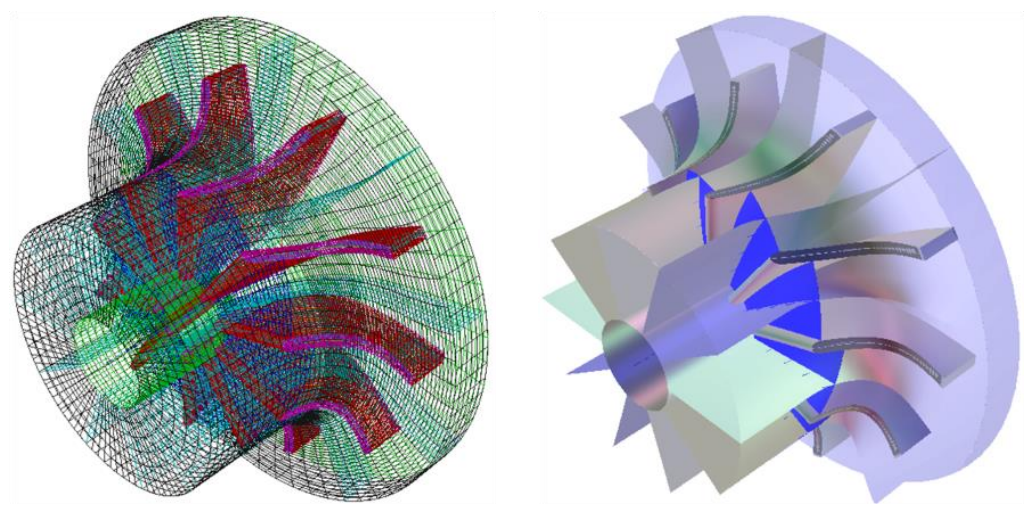

Figure 13 - The 3D model of the radial impeller.

The geometry calculation of the pump impellers

Initial operating conditions of the pump and the data for the geometry calculation of the impellers are presented in the table 1 .
The geometry calculation of the impellers was carried out of 5 times at the different values of the pump head $(H)$. The pump head is the sum of static and velocity heads.

Table 1. Operating conditions of the pump and the geometry of the radial impeller.

\begin{tabular}{|c|c|}
\hline \multicolumn{2}{|c|}{ Operating conditions } \\
\hline \multicolumn{2}{|c|}{ Duty } \\
\hline Rotational speed & $1500 \mathrm{rpm}$ \\
\hline Volume flow rate & $300 \mathrm{~m}^{3} / \mathrm{hr}$ \\
\hline Density & $1000 \mathrm{~kg} / \mathrm{m}^{3}$ \\
\hline Pump head & $5 / 10 / 15 / 20 / 25 \mathrm{~m}$ \\
\hline Inlet flow angle & $90 \mathrm{deg}$ \\
\hline Merid. velocity ratio & 1.1 \\
\hline \multicolumn{2}{|c|}{ Efficiencies } \\
\hline Hydraulic & 0.874 \\
\hline Volumetric & 0.97 \\
\hline Mechanical & 0.948 \\
\hline Pump & 0.804 \\
\hline \multicolumn{2}{|c|}{ Geometry } \\
\hline \multicolumn{2}{|c|}{ Hub diameter } \\
\hline Shaft min. diam. factor & 1.1 \\
\hline Dhub/Dshaft & 1.5 \\
\hline \multicolumn{2}{|c|}{ Tip diameter } \\
\hline Head coefficient & 0.46 \\
\hline Tip diameter & $280 \mathrm{~mm}$ \\
\hline \multicolumn{2}{|c|}{ Leading edge blade angles } \\
\hline Hub blade angle & $27 \mathrm{deg}$ \\
\hline Mean blade angle & $19 \mathrm{deg}$ \\
\hline \multicolumn{2}{|c|}{ Trailing edge blade angles } \\
\hline Blade angle & $22.5 \mathrm{deg}$ \\
\hline Rake angle & $0 \mathrm{deg}$ \\
\hline \multicolumn{2}{|c|}{ Shroud } \\
\hline Incidence & $0 \mathrm{deg}$ \\
\hline Shroud blade angle & $16 \mathrm{deg}$ \\
\hline \multicolumn{2}{|c|}{ Miscellaneous } \\
\hline Number of blades & 10 \\
\hline Thickness/tip diam. & 0.03 \\
\hline Hub inlet draft angle & $30 \mathrm{deg}$ \\
\hline
\end{tabular}




\begin{tabular}{|c|c|c|c|c|c|c|}
\hline \multirow{4}{*}{ Impact Factor: } & ISRA (India) & $=3.117$ & SIS (USA) & $=0.912$ & ICV (Poland) & $=6.630$ \\
\hline & ISI (Dubai, UAE & $=0.829$ & РИНЦ (Russia) & $=0.156$ & PIF (India) & $=1.940$ \\
\hline & GIF (Australia) & $=0.564$ & ESJI (KZ) & $=\mathbf{5 . 0 1 5}$ & IBI (India) & $=4.260$ \\
\hline & JIF & $=1.500$ & SJIF (Morocco) & $=5.667$ & & \\
\hline
\end{tabular}

The pump head varied in the range of $5-25 \mathrm{~m}$. The remaining geometric and operating parameters of the radial impeller were constant. Volume flow rate of fluid by the value of $300 \mathrm{~m}^{3} / \mathrm{h}$ was required at rotation speed of the radial impeller of $1500 \mathrm{rpm}$. Water with density of $1000 \mathrm{~kg} / \mathrm{m}^{3}$ was adopted as working fluid. The inlet flow angle is the angle at the leading edge of the impeller. The value of the inlet flow angle of fluid was taken 90 degrees for performing of the calculations. Approach flow without pre-rotation occurs at the given value of the inlet flow angle. The meridional velocity ratio is pattern of the linear velocity profile from the hub to the shroud at the leading edge of the radial impeller. Meridional velocity is less at the hub of the radial impeller at the value of the meridional velocity ratio of 1.1 .

The efficiency coefficient of the pump is defined as the coefficients product of hydraulic, volumetric, and mechanical efficiencies. The coefficients values characterize losses of useful work of the pump at friction of the mating elements of the device.

The shaft minimum diameter factor is the safety factor of the pump shaft in conditions of maximum allowable shear stress of material. The one tenth of the factor (1.1) is increasing of the shaft diameter by
$10 \%$. The ratio of the impeller hub diameter to the shaft diameter (Dhub/Dshaft) was taken 1.5. The tip diameter was set to $280 \mathrm{~mm}$ at the adopted pump head coefficient equal to 0.46 . The leading edge blade angles are characterized by the hub blade angle (27 degrees) and the mean blade angle (19 degrees). The trailing edge blade angles are characterized by the blade angle (22.5 degrees) and the rake angle ( 0 degrees). The blade angle at the shroud by the value of 16 degrees was adopted at designing of the impeller. The incidence angle at the shroud was selected by default 0 degrees.

The adopted number of the impellers blades is 10 pieces. This number of the blades gives greater control over flow direction in the pump impeller. The ratio of thickness to the tip diameter is used for determining of the impeller blade thickness. The ratio of thickness to the tip diameter equal to 0.03 indicates about a low probability of blockage to fluid flow. The hub inlet draft angle (30 degrees) is the angle between the hub and the horizontal line at the hub inlet. The hub radius of the pump impeller depends on the value of this angle.

The calculated parameters of the impeller elements in the different sections (from stub to peripheral) are presented in the summary table 2 .

Table 2. The layers parameters.

\begin{tabular}{|c|c|c|c|c|c|}
\hline \multirow{2}{*}{ Parameters } & \multicolumn{5}{|c|}{ Pump head, m } \\
\cline { 2 - 6 } & $\mathbf{5}$ & $\mathbf{1 0}$ & $\mathbf{1 5}$ & $\mathbf{2 0}$ \\
\hline \multicolumn{5}{|c|}{ Value } \\
\hline 1. Layer & \multicolumn{5}{|c|}{$\mathbf{~}$} \\
\hline B2B throat length 0 & 23.2998 & 30.7859 & 33.0261 & 35.0692 & 36.0579 \\
\hline Segment 0 (0 to 0) & 23.2997 & 30.7559 & 32.9884 & 35.018 & 36.0186 \\
\hline Crv throat length 0 & 23.2997 & 30.7559 & 32.9884 & 35.018 & 36.0186 \\
\hline LE pitch & 32.6379 & 34.94 & 38.1708 & 42.7978 & 46.9774 \\
\hline TE pitch (S) & 64.7102 & 97.6394 & 121.378 & 138.501 & 152.753 \\
\hline Centroid:Z & -10.3934 & -6.99712 & -3.1923 & -1.75024 & -1.5597 \\
\hline Centroid:R & 48.4668 & 67.2025 & 81.5823 & 92.5206 & 101.509 \\
\hline Centroid:T & -38.8 & -38.3 & -45.6 & -54.0 & -61.0 \\
\hline Centroid:Mp & 0.589379 & 0.805987 & 0.877109 & 0.864041 & 0.849385 \\
\hline Centroid:M & 23.0234 & 38.4933 & 48.5125 & 54.0931 & 58.5061 \\
\hline Airfoil area & 327.405 & 582.996 & 893.181 & 1224.9 & 1574.36 \\
\hline 2. Blade \& layer & \multicolumn{5}{|c|}{ Value } \\
\hline 3D meanline length & 67.8987 & 99.3529 & 130.444 & 158.032 & 183.85 \\
\hline Camber length & 67.9001 & 99.3554 & 130.448 & 158.038 & 183.859 \\
\hline Cord length (C) & 67.1055 & 96.7405 & 127.599 & 155.85 & 182.175 \\
\hline Meridional length (M) & 39.9246 & 65.4698 & 83.0066 & 93.8869 & 102.905 \\
\hline Stagger angle & -53.5 & -47.4 & -49.4 & -53.0 & -55.6 \\
\hline Solidity (C/S) & 1.03702 & 0.990793 & 1.05126 & 1.12526 & 1.19261 \\
\hline Pitch cord ratio (S/C) & 0.964305 & 1.00929 & 0.951243 & 0.888686 & 0.838494 \\
\hline 3. Bezier & \multicolumn{5}{|c|}{ Value } \\
\hline Stagger angle & 51.8 & 43.6 & 45.5 & 49.8 & 53.0 \\
\hline LE theta angle & 0.1 & 0.2 & 0.2 & 0.2 & 0.2 \\
\hline LE beta angle & 41.5 & 31.4 & 33.5 & 39.6 & 44.1 \\
\hline TE beta angle & 67.7 & 68.1 & 67.9 & 67.7 & 67.6 \\
\hline LE wedge angle & -2.2 & -2.2 & -2.8 & -3.1 & -3.2 \\
\hline
\end{tabular}




\begin{tabular}{|c|c|c|c|c|c|c|}
\hline \multirow{4}{*}{ Impact Factor: } & ISRA (India) & $=3.117$ & SIS (USA) & $=0.912$ & ICV (Poland) & $=6.630$ \\
\hline & ISI (Dubai, UAF & $=0.829$ & РИНЦ (Russia) & $=0.156$ & PIF (India) & $=1.940$ \\
\hline & GIF (Australia) & $=0.564$ & ESJI (KZ) & $=5.015$ & IBI (India) & $=4.260$ \\
\hline & JIF & $=1.500$ & SJIF (Morocco) & $=5.667$ & & \\
\hline
\end{tabular}

\begin{tabular}{|c|c|c|c|c|c|}
\hline TE wedge angle & 0.6 & 0.6 & 0.6 & 0.6 & 0.6 \\
\hline LE thickness & 4.9514 & 5.99524 & 6.96641 & 7.85943 & 8.66235 \\
\hline TE thickness & 5.01253 & 6.07905 & 7.06994 & 7.98399 & 8.80553 \\
\hline 4. Advanced side1 point & \multicolumn{5}{|c|}{ Value } \\
\hline First point $\% \mathrm{M}^{\prime}$ & 20.0 & 20.0 & 20.0 & 20.0 & 20.0 \\
\hline Last point $\% \mathrm{M}^{\prime}$ & 80.0 & 80.0 & 80.0 & 80.0 & 80.0 \\
\hline Linear point \% $\mathrm{M}^{\prime}$ & 30.0 & 30.0 & 30.0 & 30.0 & 30.0 \\
\hline 5. Advanced side2 point & \multicolumn{5}{|c|}{ Value } \\
\hline First point $\% \mathrm{M}^{\prime}$ & 30.0 & 30.0 & 30.0 & 30.0 & 30.0 \\
\hline Last point $\% \mathrm{M}^{\prime}$ & 80.0 & 80.0 & 80.0 & 80.0 & 80.0 \\
\hline Linear point $\% \mathrm{M}^{\prime}$ & 0.0 & 0.0 & 0.0 & 0.0 & 0.0 \\
\hline \multicolumn{6}{|c|}{ Span: 0.2500} \\
\hline 1. Layer & \multicolumn{5}{|c|}{ Value } \\
\hline B2B throat length 0 & 26.0818 & 38.4671 & 39.2628 & 38.2518 & 37.3117 \\
\hline Segment $0(0$ to 0$)$ & 26.0781 & 38.3506 & 39.1432 & 38.1645 & 37.2594 \\
\hline Crv throat length 0 & 26.0781 & 38.3506 & 39.1432 & 38.1645 & 37.2594 \\
\hline LE pitch & 47.3035 & 48.9666 & 51.3608 & 54.8135 & 57.9361 \\
\hline TE pitch (S) & 75.8122 & 101.529 & 122.008 & 138.501 & 152.753 \\
\hline Centroid:Z & -25.891 & -25.6256 & -20.0568 & -16.1472 & -13.9837 \\
\hline Centroid:R & 59.7521 & 73.868 & 85.6612 & 95.5541 & 104.129 \\
\hline Centroid:T & -38.0 & -37.9 & -45.0 & -53.2 & -60.1 \\
\hline Centroid:Mp & 0.420255 & 0.55918 & 0.633694 & 0.658856 & 0.676587 \\
\hline Centroid:M & 21.8246 & 32.8187 & 41.1055 & 46.7755 & 51.7116 \\
\hline Airfoil area & 373.976 & 572.247 & 861.731 & 1199.33 & 1559.14 \\
\hline 2. Blade \& layer & \multicolumn{5}{|c|}{ Value } \\
\hline 3D meanline length & 77.6836 & 97.8091 & 126.18 & 155.099 & 182.455 \\
\hline Camber length & 77.6849 & 97.8112 & 126.184 & 155.104 & 182.463 \\
\hline Cord length (C) & 77.4054 & 96.77 & 125.068 & 154.259 & 181.797 \\
\hline Meridional length (M) & 39.171 & 57.2882 & 72.3401 & 83.6417 & 93.5598 \\
\hline Stagger angle & -59.6 & -53.7 & -54.7 & -57.2 & -59.0 \\
\hline Solidity $(\mathrm{C} / \mathrm{S})$ & 1.02102 & 0.953126 & 1.02508 & 1.11377 & 1.19014 \\
\hline Pitch cord ratio (S/C) & 0.979417 & 1.04918 & 0.975534 & 0.89785 & 0.840238 \\
\hline \multicolumn{6}{|c|}{ Span: 0.5000} \\
\hline 1. Layer & \multicolumn{5}{|c|}{ Value } \\
\hline B2B throat length 0 & 28.1162 & 36.7428 & 37.906 & 36.4677 & 35.5472 \\
\hline Segment $0(0$ to 0$)$ & 28.0973 & 36.6617 & 37.7949 & 36.3734 & 35.4738 \\
\hline Crv throat length 0 & 28.0973 & 36.6617 & 37.7949 & 36.3734 & 35.4738 \\
\hline LE pitch & 61.9692 & 62.9933 & 64.5508 & 66.8292 & 68.8948 \\
\hline TE pitch $(\mathrm{S})$ & 86.9141 & 105.419 & 122.638 & 138.501 & 152.753 \\
\hline Centroid:Z & -41.6684 & -44.5786 & -37.1857 & -30.729 & -26.5341 \\
\hline Centroid:R & 70.985 & 80.2918 & 89.5001 & 98.4238 & 106.642 \\
\hline Centroid:T & -37.2 & -37.2 & -44.1 & -52.2 & -58.9 \\
\hline Centroid:Mp & 0.320383 & 0.39399 & 0.459632 & 0.504708 & 0.54221 \\
\hline Centroid:M & 20.7071 & 27.2334 & 33.9249 & 39.7815 & 45.2645 \\
\hline Airfoil area & 427.293 & 576.717 & 848.986 & 1191.14 & 1559.11 \\
\hline 2. Blade \& layer & \multicolumn{5}{|c|}{ Value } \\
\hline 3D meanline length & 88.7124 & 98.91 & 124.694 & 154.393 & 182.775 \\
\hline Camber length & 88.7137 & 98.9117 & 124.697 & 154.398 & 182.783 \\
\hline Cord length $(\mathrm{C})$ & 88.6499 & 98.6635 & 124.434 & 154.188 & 182.603 \\
\hline Meridional length (M) & 38.881 & 49.716 & 62.3336 & 73.9907 & 84.7322 \\
\hline Stagger angle & -64.0 & -59.7 & -59.9 & -61.3 & -62.4 \\
\hline Solidity $(\mathrm{C} / \mathrm{S})$ & 1.01997 & 0.935921 & 1.01464 & 1.11326 & 1.19541 \\
\hline Pitch cord ratio (S/C) & 0.98042 & 1.06847 & 0.985568 & 0.898262 & 0.83653 \\
\hline \multicolumn{6}{|c|}{ Span: 0.7500} \\
\hline 1. Layer & \multicolumn{5}{|c|}{ Value } \\
\hline B2B throat length 0 & 28.6997 & 32.6836 & 33.1581 & 32.5563 & 32.419 \\
\hline Segment $0(0$ to 0$)$ & 28.6716 & 32.5919 & 33.0416 & 32.4384 & 32.3101 \\
\hline Crv throat length 0 & 28.6716 & 32.5919 & 33.0416 & 32.4384 & 32.3101 \\
\hline LE pitch & 76.6348 & 77.0199 & 77.7408 & 78.845 & 79.8535 \\
\hline
\end{tabular}




\begin{tabular}{|c|c|c|c|c|c|c|}
\hline \multirow{4}{*}{ Impact Factor: } & ISRA (India) & $=3.117$ & SIS (USA) & $=0.912$ & ICV (Poland) & $=6.630$ \\
\hline & ISI (Dubai, UAF & $=0.829$ & РИНЦ (Russia) & $=0.156$ & PIF (India) & $=1.940$ \\
\hline & GIF (Australia) & $=0.564$ & ESJI (KZ) & $=\mathbf{5 . 0 1 5}$ & IBI (India) & $=4.260$ \\
\hline & JIF & $=1.500$ & SJIF (Morocco) & $=5.667$ & & \\
\hline
\end{tabular}

\begin{tabular}{|c|c|c|c|c|c|}
\hline TE pitch (S) & 98.0161 & 109.308 & 123.268 & 138.501 & 152.753 \\
\hline Centroid: $Z$ & -57.6932 & -63.9253 & -54.7011 & -45.5738 & -39.2533 \\
\hline Centroid: $\mathrm{R}$ & 82.2844 & 86.8073 & 93.3748 & 101.29 & 109.141 \\
\hline Centroid:T & -36.3 & -36.0 & -42.8 & -50.7 & -57.6 \\
\hline Centroid:Mp & 0.255572 & 0.279544 & 0.33318 & 0.388123 & 0.437373 \\
\hline Centroid:M & 19.7555 & 22.1866 & 27.4634 & 33.4823 & 39.4281 \\
\hline Airfoil area & 486.85 & 597.648 & 856.517 & 1201.45 & 1575.2 \\
\hline 2. Blade \& layer & \multicolumn{5}{|c|}{ Value } \\
\hline 3D meanline length & 100.576 & 102.451 & 125.841 & 155.728 & 184.642 \\
\hline Camber length & 100.578 & 102.453 & 125.843 & 155.732 & 184.649 \\
\hline Cord length $(\mathrm{C})$ & 100.554 & 102.418 & 125.807 & 155.697 & 184.619 \\
\hline Meridional length (M) & 39.0661 & 43.0816 & 53.3736 & 65.2198 & 76.6254 \\
\hline Stagger angle & -67.1 & -65.1 & $\begin{array}{l}-64.9 \\
\end{array}$ & -65.2 & -65.5 \\
\hline Solidity $(\mathrm{C} / \mathrm{S})$ & 1.02589 & 0.936967 & 1.0206 & 1.12415 & 1.20861 \\
\hline Pitch cord ratio $(\mathrm{S} / \mathrm{C})$ & 0.974762 & 1.06727 & 0.979817 & 0.889558 & 0.827395 \\
\hline \multicolumn{6}{|c|}{ Span: 1.000} \\
\hline 1. Layer & \multicolumn{5}{|c|}{ Value } \\
\hline B2B throat length 0 & 29.1029 & 28.7079 & 28.172 & 28.197 & 28.7868 \\
\hline Segment $0(0$ to 0$)$ & 29.0676 & 28.6157 & 28.0639 & 28.081 & 28.674 \\
\hline Crv throat length 0 & 29.0676 & 28.6157 & 28.0639 & 28.081 & 28.674 \\
\hline LE pitch & 91.3006 & 91.0465 & 90.9308 & 90.8607 & 90.8121 \\
\hline TE pitch $(\mathrm{S})$ & 109.118 & 113.198 & 123.898 & 138.501 & 152.753 \\
\hline Centroid:Z & -73.928 & -83.7056 & -72.748 & -60.7837 & -52.1925 \\
\hline Centroid:R & 93.7295 & 93.7777 & 97.6091 & 104.321 & 111.722 \\
\hline Centroid:T & -35.4 & -34.5 & -40.9 & -49.0 & -55.9 \\
\hline Centroid:Mp & 0.211152 & 0.202424 & 0.245067 & 0.302507 & 0.357096 \\
\hline Centroid:M & 19.0061 & 18.1594 & 22.307 & 28.2962 & 34.4824 \\
\hline Airfoil area & 551.495 & 635.345 & 885.252 & 1230.95 & 1607.84 \\
\hline 2. Blade \& layer & \multicolumn{5}{|c|}{ Value } \\
\hline 3D meanline length & 113.026 & 108.032 & 129.286 & 158.847 & 187.866 \\
\hline Camber length & 113.028 & 108.033 & 129.289 & 158.851 & 187.873 \\
\hline Cord length (C) & 112.936 & 107.938 & 129.203 & 158.787 & 187.834 \\
\hline Meridional length (M) & 39.7187 & 37.8792 & 46.07 & 57.7218 & 69.4783 \\
\hline Stagger angle & -69.4 & -69.5 & -69.1 & -68.7 & -68.3 \\
\hline Solidity $(\mathrm{C} / \mathrm{S})$ & 1.03499 & 0.953535 & 1.04282 & 1.14646 & 1.22966 \\
\hline Pitch cord ratio $(\mathrm{S} / \mathrm{C})$ & 0.966192 & 1.04873 & 0.958942 & 0.872247 & 0.813231 \\
\hline 3. Bezier & \multicolumn{5}{|c|}{ Value } \\
\hline Stagger angle & 69.5 & 69.6 & 69.3 & 68.9 & 68.5 \\
\hline LE theta angle & 0.0 & 0.0 & 0.0 & 0.0 & 0.0 \\
\hline LE beta angle & 73.9 & 74.1 & 73.3 & 72.1 & 70.9 \\
\hline TE beta angle & 66.7 & 66.7 & 66.8 & 67.0 & 67.1 \\
\hline LE wedge angle & -0.1 & -0.1 & -0.1 & -0.2 & -0.3 \\
\hline TE wedge angle & 0.3 & 0.5 & 0.6 & 0.6 & 0.6 \\
\hline LE thickness & 4.97315 & 6.03083 & 7.01342 & 7.91714 & 8.72736 \\
\hline TE thickness & 4.99269 & 6.06864 & 7.06667 & 7.98304 & 8.80505 \\
\hline 4. Advanced side1 point & \multicolumn{5}{|c|}{ Value } \\
\hline First point \% $\mathrm{M}^{\prime}$ & 20.0 & 20.0 & 20.0 & 20.0 & 20.0 \\
\hline Last point \% $\mathrm{M}^{\prime}$ & 80.0 & 80.0 & 80.0 & 80.0 & 80.0 \\
\hline Linear point $\% \mathrm{M}^{\prime}$ & 30.0 & 30.0 & 30.0 & 30.0 & 30.0 \\
\hline 5. Advanced side2 point & \multicolumn{5}{|c|}{ Value } \\
\hline First point $\% \mathrm{M}^{\prime}$ & 30.0 & 30.0 & 30.0 & 30.0 & 30.0 \\
\hline Last point \% $\mathrm{M}^{\prime}$ & 80.0 & 80.0 & 80.0 & 80.0 & 80.0 \\
\hline Linear point $\% \mathrm{M}^{\prime}$ & 0.0 & 0.0 & 0.0 & 0.0 & 0.0 \\
\hline
\end{tabular}

Main integral characteristics of the cross sections of the profiled pump impellers blades are given in the table. Span 0.000 is the stub section of the impeller blade; span 1.000 is the peripheral section of the impeller blade. The calculation of a pitch at the leading edge of the blade ( $L E$ pitch), the pitch at the trailing edge of the blade (TE pitch), the airfoil area, a cord length $(C)$, the meridional length $(M)$, the stagger angle, solidity $(C / S)$, the pitch cord ratio $(S / C)$ and the other parameters was performed. 


\begin{tabular}{|c|c|c|c|c|c|c|}
\hline \multirow{4}{*}{ Impact Factor: } & ISRA (India) & $=3.117$ & SIS (USA) & $=0.912$ & ICV (Poland) & $=6.630$ \\
\hline & ISI (Dubai, UAE & $=0.829$ & РИНЦ (Russia) & $=0.156$ & PIF (India) & $=1.940$ \\
\hline & GIF (Australia) & $=0.564$ & ESJI (KZ) & $=\mathbf{5 . 0 1 5}$ & IBI (India) & $=4.260$ \\
\hline & JIF & $=1.500$ & SJIF (Morocco) & $=5.667$ & & \\
\hline
\end{tabular}

At considering of the blades characteristics in the stub and peripheral sections, it could be argued that:

1. The pitch at the leading edge of the impeller blade in the stub section increases with increasing of the pump head, and the pitch in the peripheral section decreases.

2. The pitches at the trailing edge of the impeller blade are the same in the stub and peripheral sections at the pump heads of 20 and $25 \mathrm{~m}$.

3. Decreasing of the airfoil area of the impeller blade is almost twice observed at the pump head of 5 m.

The contours and the dependencies graphs of the main elements geometry of the impellers from the pump head are presented in the Fig. $14-45$. The flowing parts of the impellers blades and fluid flow direction are displayed in the meridional configuration. The blade channels (two adjacent impeller blades) are shown in the Fig. 15. Theta is circumferential coordinate of the mean line points in a cylindrical coordinate system, an axis of which coincides with the axis of an engine. Beta (axial) is the angle between a tangent to the mean line of the profile and the axis of the impeller. Theta changes in the range of $0 . . .-100$ degrees. The maximum negative value of the angle is reached at the trailing edge of the blade at the pump head of $25 \mathrm{~m}$. Beta changes in the range of $120 \ldots 165$ degrees. The value of the angle decreases in the stub section of the impeller blade. Thickness changing of the impellers blades is in the range of 0.09 to $0.5 \mathrm{~mm}$. Changing of the inverse radius of curvature of the blade at the hub and the shroud of the impeller in meridional fraction from the leading edge to the trailing edge are shown in the Fig. 19. Maximum increasing of the inverse radius of curvature of the blade is observed at the trailing edge. The dependencies of the inverse radius of curvature of the blade in meridional fraction from the leading edge to the trailing edge (the parameters mean, side1 and side2) are presented in the Fig. 20. Mean is a default option and specifies that the theta values are for location of the mean line. Sidel specifies that the theta values locate the side of the blade (at the larger theta value). Side 2 specifies that the theta values locate the side of the blade (at the smaller theta value). The inverse radius of curvature of the impeller blade (the leading edge) at mean and sidel has the positive values. The values changing of theta and beta at the leading and trailing edges of the impellers blades in the range of the stub/peripheral sections are defined in the Fig. 21 and 22. Theta at the leading edge of the blade is 0 degrees; theta at the trailing edge is $65 . . .92$ degrees. In the stub section Beta at the leading edge of the blade is more than at the trailing edge, and in the peripheral section is vice versa. A height distribution of the minor and major radii of ellipses of the leading edge of the impeller blade is shown in the Fig. 23. The relative height of the impeller blade is plotted along the horizontal axis, the values of the edges radii in $\mathrm{mm}$ are plotted along the vertical axis. Changing of the lean angle of the impeller blade at the hub and the shroud from the relative axial chord is calculated in the Fig. 24. Significant changing of the values of this angle is determined at the pump head of $20-25 \mathrm{~m}$. The quasi-orthogonal area was calculated with and without the flow angle correction of fluid, with and without the blades. It is determined that the quasiorthogonal area of the blade with correction in $2-3$ times is less than the quasi-orthogonal area of the blade without correction. The airfoil areas of the impellers blades in the height are calculated on the graphs (the Fig. 26). The airfoil area of the blade from the hub to the shroud increases linearly at the pump head of $5 \mathrm{~m}$. The airfoil area decreases according to a non-linear law at the pump head of 15 $-20 \mathrm{~m}$ at the distance from the stub section to the mean line, and the airfoil area increases according to the non-linear law at the distance from the mean line to the peripheral section. The maximum spherical diameter at the leading edge of the impeller blade is $85 \mathrm{~mm}$ at the pump head of $10 \mathrm{~m}$. This is the maximum value of this parameter. The dependencies of theta and beta from M-Prime (the current blade angle with the horizontal axis using the radius normalized meridional distance), $M$ (the current blade angle with the horizontal axis using the meridional distance), $Z$ (the current blade angle with the horizontal axis using axial location) and $R$ (the current blade angle with the horizontal axis using radial location) are shown in the Fig. $28-31$. Changing of theta and beta from the stub to peripheral sections of the impellers blades are presented in the Fig. $32-39$. Theta from $M$ at the leading edge of the blade (in all sections) is 0 degrees; theta from $M$ at the trailing edge is 65 degrees. The impeller blade profile has maximum curvature at the high pump heads. The dependencies of beta from theta for all sections are presented in the Fig. 40. It is noted that in the stub section beta decreases, and in the peripheral section beta increases. 


\begin{tabular}{|c|c|c|c|c|c|c|}
\hline \multirow{4}{*}{ Impact Factor: } & ISRA (India) & $=3.117$ & SIS (USA) & $=0.912$ & ICV (Poland) & $=6.630$ \\
\hline & ISI (Dubai, UAE & $=0.829$ & РИНЦ (Russia) & $=0.156$ & PIF (India) & $=1.940$ \\
\hline & GIF (Australia) & $=0.564$ & ESJI (KZ) & $=5.015$ & IBI (India) & $=4.260$ \\
\hline & JIF & $=1.500$ & SJIF (Morocco) & $=5.667$ & & \\
\hline
\end{tabular}

A

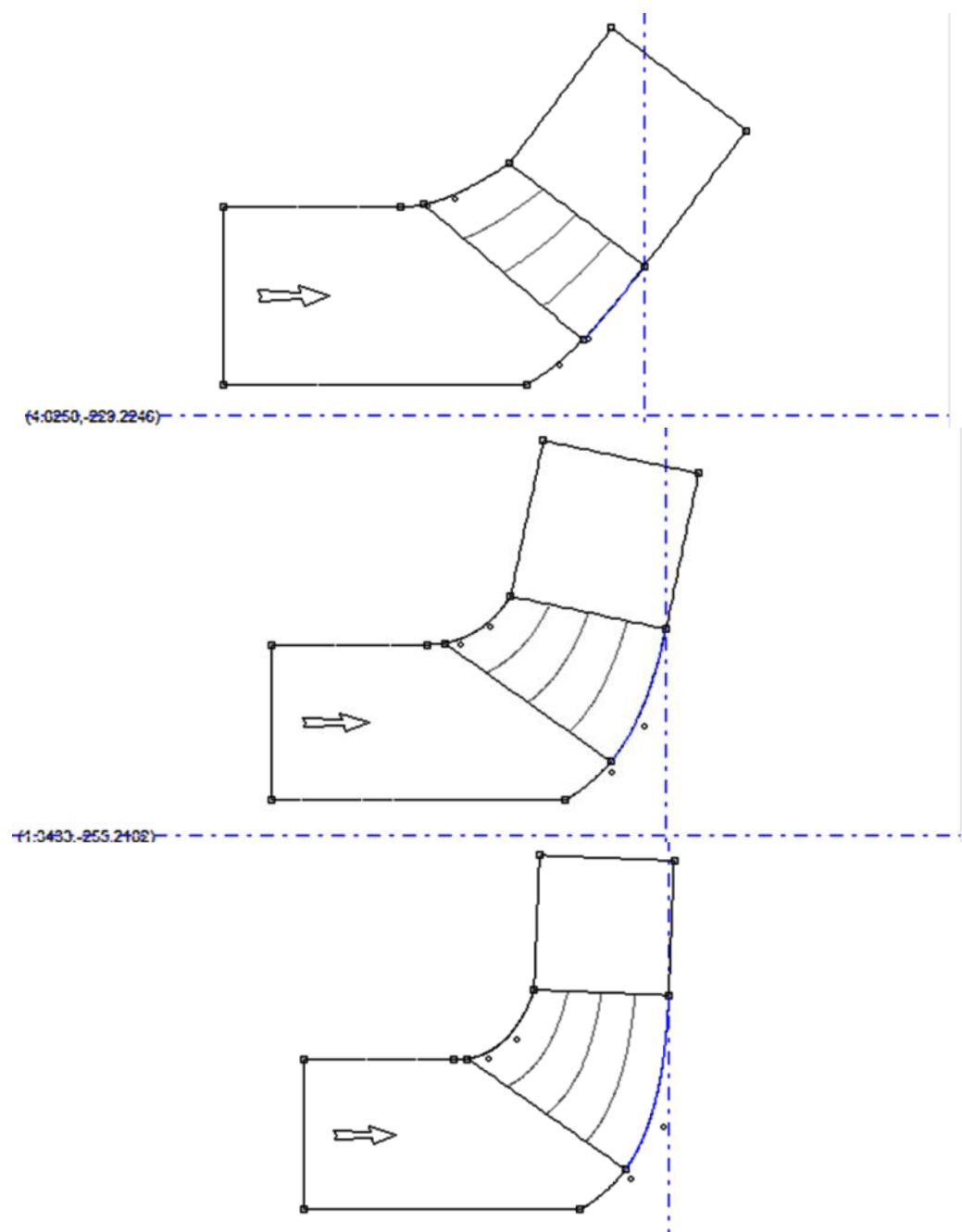

B

C

D

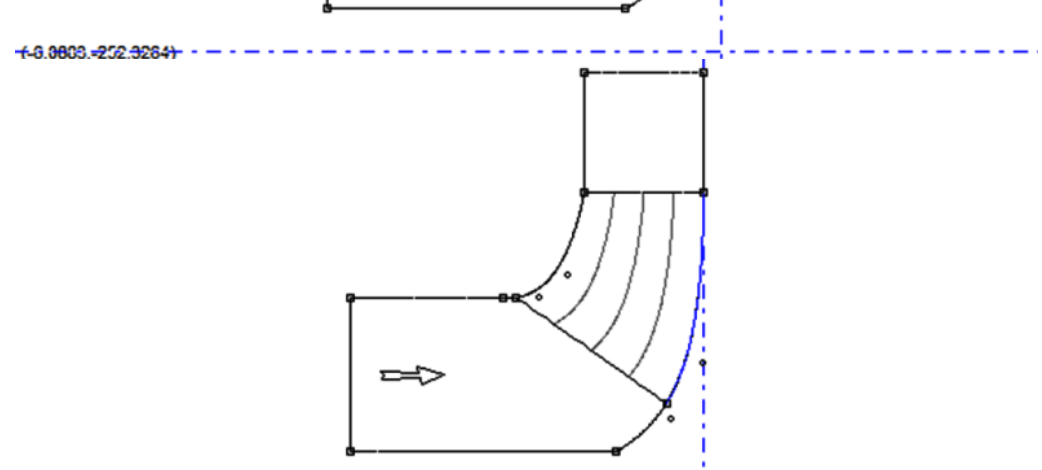

$\mathbf{E}$

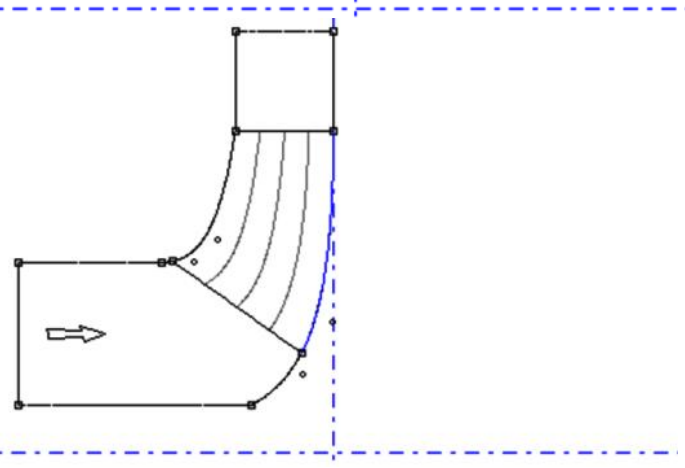

Figure 14 - The meridional configuration of the impeller blade: A) $H=5 \mathrm{~m}, \mathrm{~B}) H=10 \mathrm{~m}, \mathrm{C}) H=15 \mathrm{~m}$, D) $H$ $=20 \mathrm{~m}, \mathrm{E}) H=25 \mathrm{~m}$. 


\begin{tabular}{|c|c|c|c|c|c|c|}
\hline \multirow{4}{*}{ Impact Factor: } & ISRA (India) & $=3.117$ & SIS (USA) & $=0.912$ & ICV (Poland) & $=6.630$ \\
\hline & ISI (Dubai, UAE & $=0.829$ & РИНЦ (Russia & $=0.156$ & PIF (India) & $=1.940$ \\
\hline & GIF (Australia) & $=0.564$ & ESJI (KZ) & $=5.015$ & IBI (India) & $=4.260$ \\
\hline & JIF & $=1.500$ & SJIF (Morocco & $=5.667$ & & \\
\hline
\end{tabular}

A

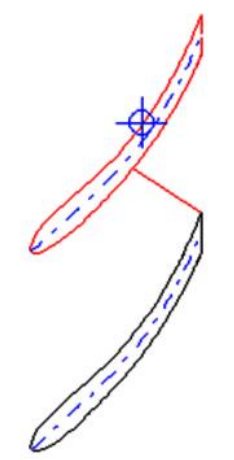

B

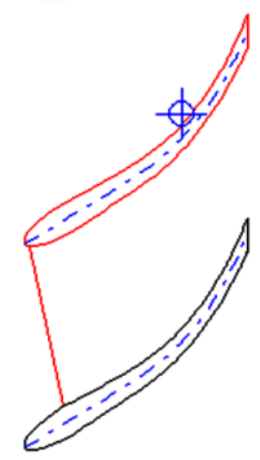

C

$(-0.9750 .-1.1072)$

$(-1.9956,-1.1889)$

- 0 - $30.7859(0: 0)$

$-0-33.0261(0: 0)$

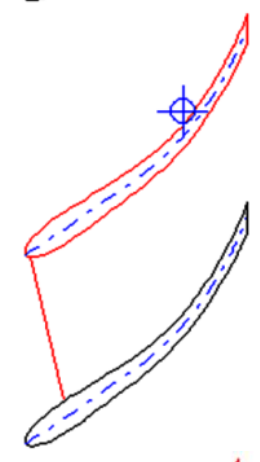

(2.2355,-1.3872)

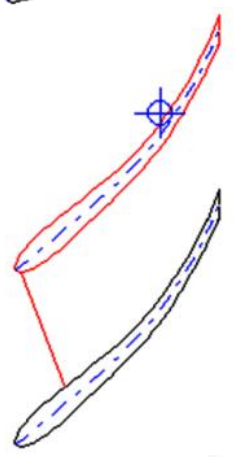

$(-0.3710,-1.5791)$

$-0-36.0579(0: 0)$

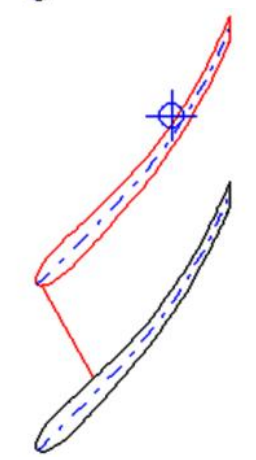

(2.5100.-1.7611)

Figure 15 - The blade-to-blade view: A) $H=5 \mathrm{~m}, \mathrm{~B}) H=10 \mathrm{~m}, \mathrm{C}) H=15 \mathrm{~m}, \mathrm{D}) H=20 \mathrm{~m}, \mathrm{E}) H=25 \mathrm{~m}$. 


\begin{tabular}{|c|c|c|c|c|c|c|}
\hline \multirow{4}{*}{ Impact Factor: } & ISRA (India) & $=3.117$ & SIS (USA) & $=0.912$ & ICV (Poland) & $=6.630$ \\
\hline & ISI (Dubai, UAE & $=0.829$ & РИНЦ (Russia) & $=0.156$ & PIF (India) & $=1.940$ \\
\hline & GIF (Australia) & $=0.564$ & ESJI (KZ) & $=5.015$ & IBI (India) & $=4.260$ \\
\hline & JIF & $=1.500$ & SJIF (Morocco) & $=5.667$ & & \\
\hline
\end{tabular}

A
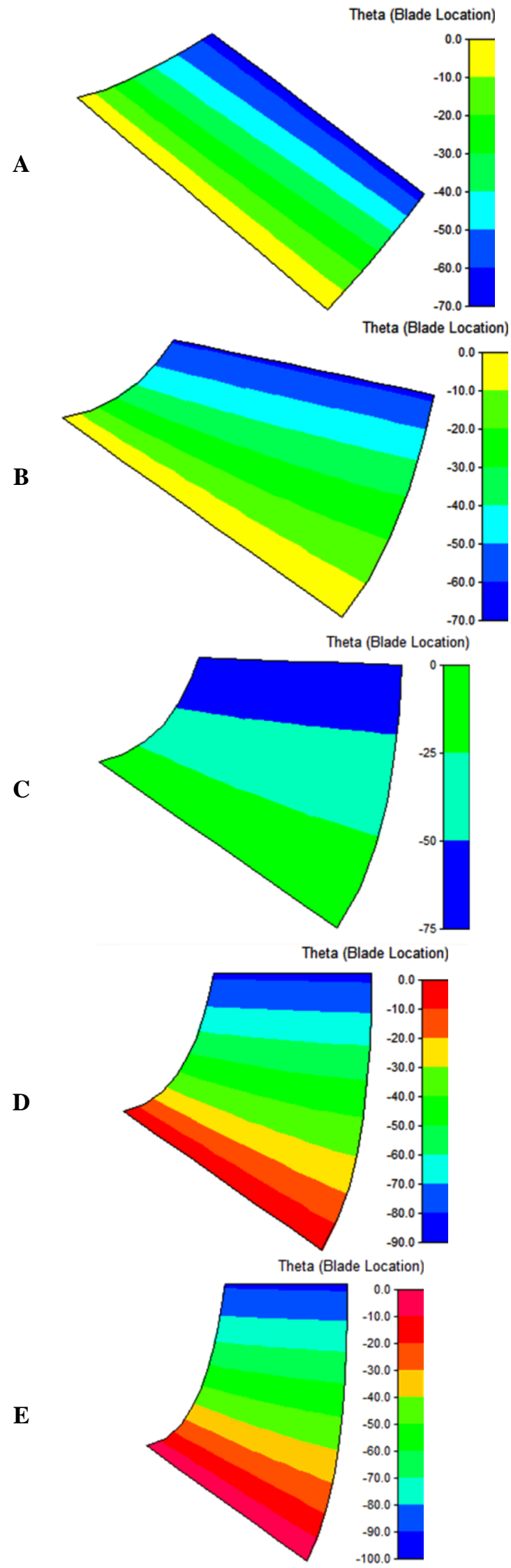

Figure 16 - Theta (blade location): A) $H=5 \mathrm{~m}, \mathrm{~B}) H=10 \mathrm{~m}, \mathrm{C}) H=15 \mathrm{~m}, \mathrm{D}) H=20 \mathrm{~m}, \mathrm{E}) H=25 \mathrm{~m}$. 


\begin{tabular}{|c|c|c|c|c|c|c|}
\hline \multirow{4}{*}{ Impact Factor: } & ISRA (India) & $=3.117$ & SIS (USA) & $=0.912$ & ICV (Poland) & $=6.630$ \\
\hline & ISI (Dubai, UAE & $=0.829$ & РИНЦ (Russia) & $=0.156$ & PIF (India) & $=1.940$ \\
\hline & GIF (Australia) & $=0.564$ & ESJI (KZ) & $=5.015$ & IBI (India) & $=4.260$ \\
\hline & JIF & $=1.500$ & SJIF (Morocco) & $=5.667$ & & \\
\hline
\end{tabular}

A
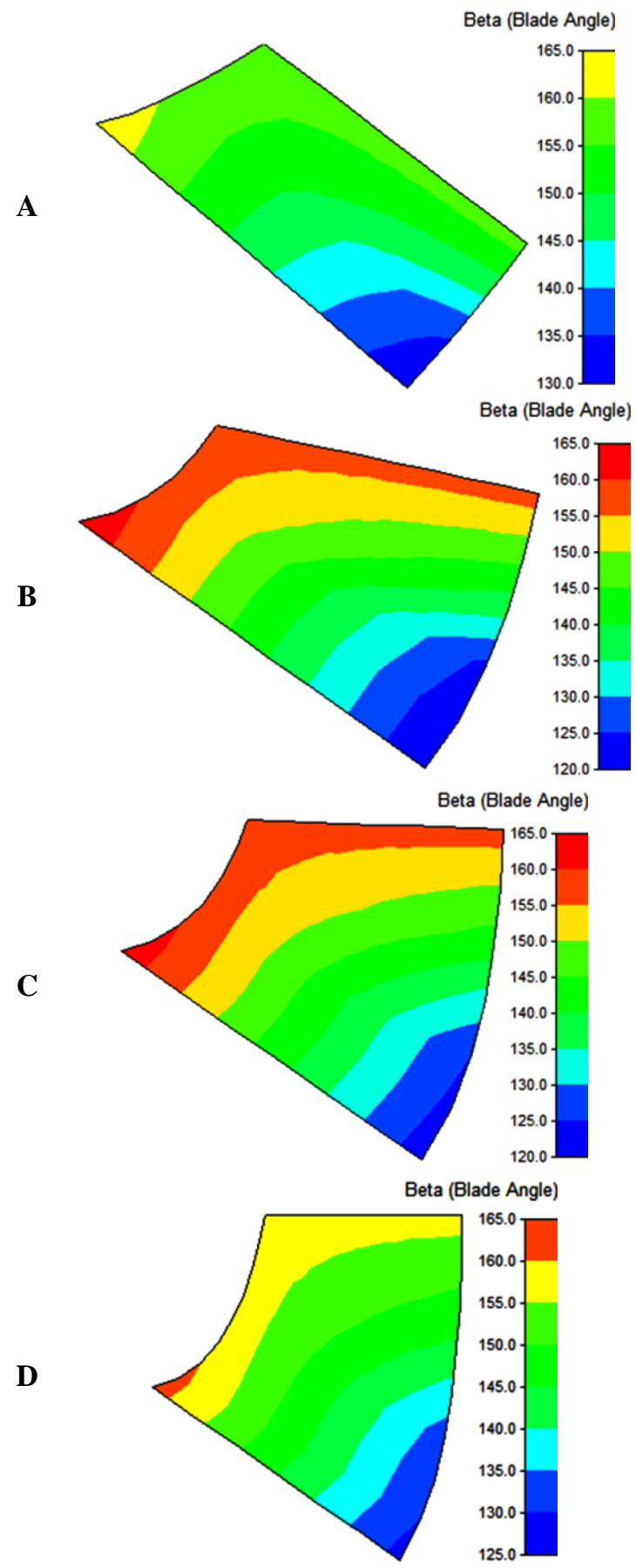

D

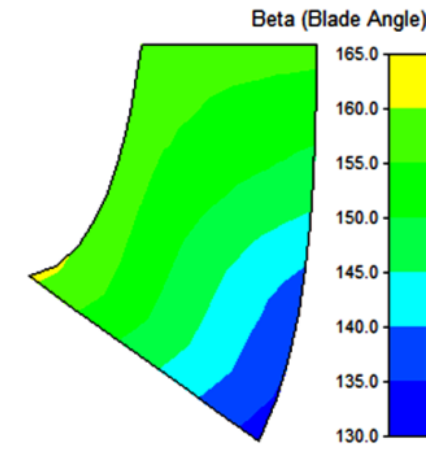

Figure 17 - Beta (blade angle): A) $H=5 \mathrm{~m}, \mathrm{~B}) H=10 \mathrm{~m}, \mathrm{C}) H=15 \mathrm{~m}, \mathrm{D}) H=20 \mathrm{~m}, \mathrm{E}) H=25 \mathrm{~m}$. 


\begin{tabular}{|c|c|c|c|c|c|c|}
\hline \multirow{4}{*}{ Impact Factor: } & ISRA (India) & $=3.117$ & SIS (USA) & $=0.912$ & ICV (Poland) & $=6.630$ \\
\hline & ISI (Dubai, UAE & $=0.829$ & РИНЦ (Russia) & $=0.156$ & PIF (India) & $=1.940$ \\
\hline & GIF (Australia) & $=0.564$ & ESJI (KZ) & $=\mathbf{5 . 0 1 5}$ & IBI (India) & $=4.260$ \\
\hline & JIF & $=1.500$ & SJIF (Morocco) & $=5.667$ & & \\
\hline
\end{tabular}

A
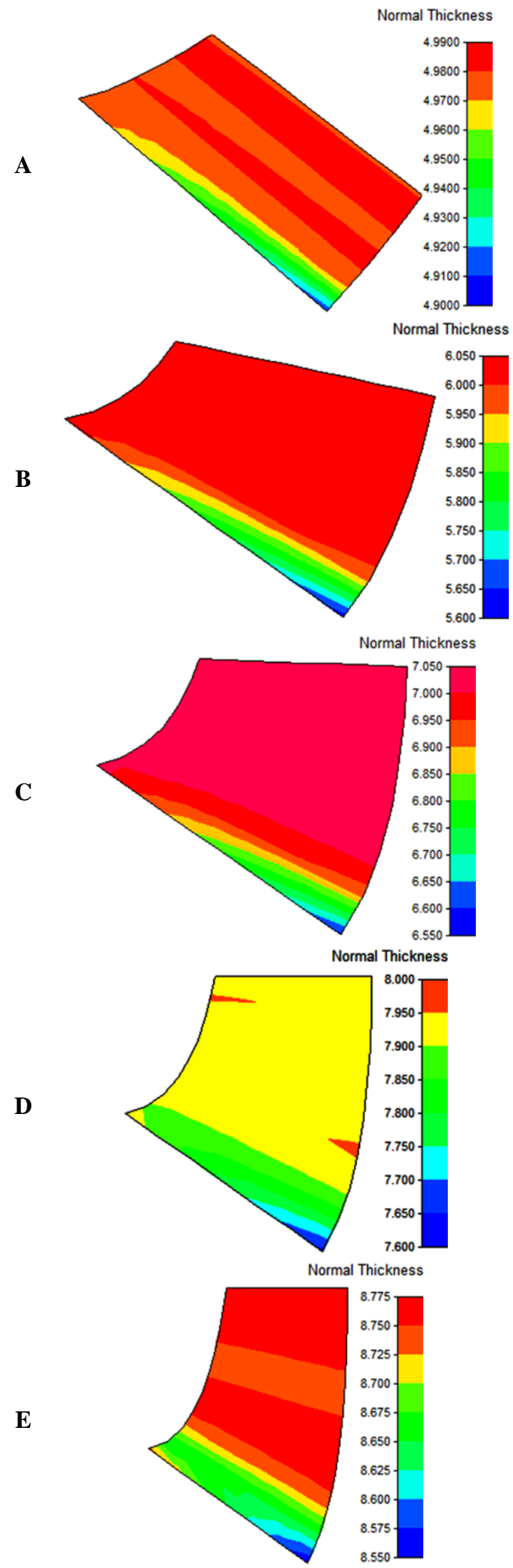

Figure 18 - Normal thickness: A) $H=5 \mathrm{~m}, \mathrm{~B}) H=10 \mathrm{~m}, \mathrm{C}) H=15 \mathrm{~m}$, D) $H=20 \mathrm{~m}, \mathrm{E}) H=25 \mathrm{~m}$. 


\begin{tabular}{|c|c|c|c|c|c|c|}
\hline \multirow{4}{*}{ Impact Factor: } & ISRA (India) & $=3.117$ & SIS (USA) & $=0.912$ & ICV (Poland) & $=6.630$ \\
\hline & ISI (Dubai, UAE & $=0.829$ & РИНЦ (Russia & $=0.156$ & PIF (India) & $=1.940$ \\
\hline & GIF (Australia) & $=0.564$ & ESJI (KZ) & $=\mathbf{5 . 0 1 5}$ & IBI (India) & $=4.260$ \\
\hline & JIF & $=1.500$ & SJIF (Morocco & $=5.667$ & & \\
\hline
\end{tabular}

A
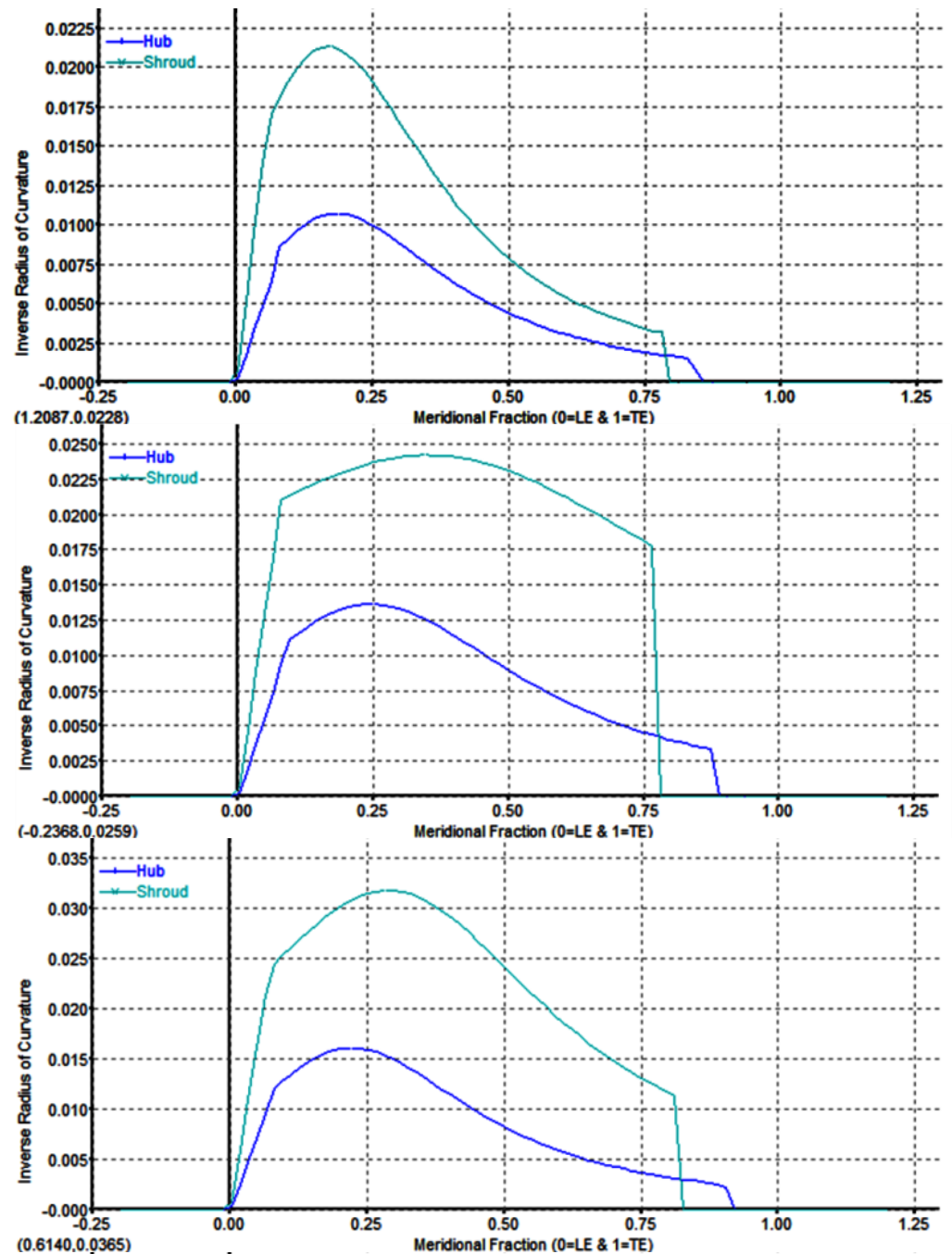

C
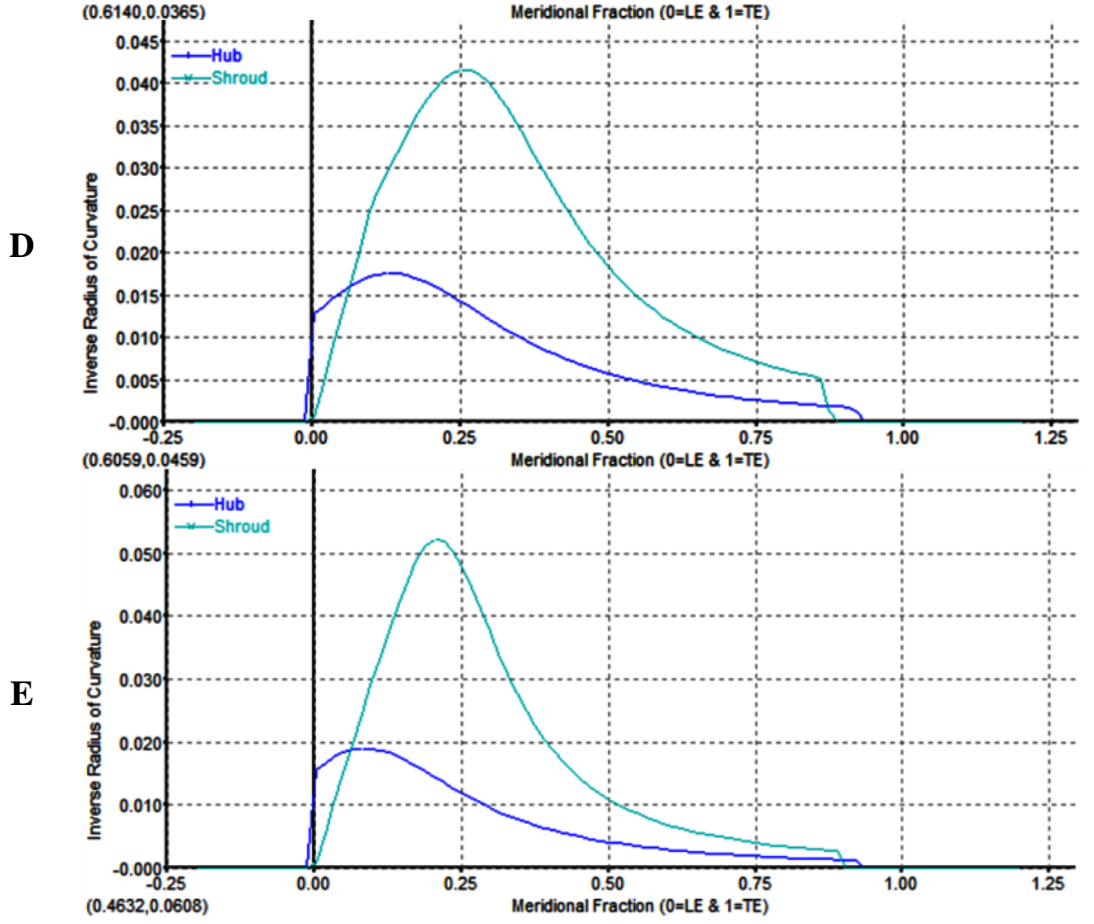

Figure 19 - The meridional curvature graph: A) $H=5 \mathrm{~m}, \mathrm{~B}) H=10 \mathrm{~m}, \mathrm{C}) H=15 \mathrm{~m}, \mathrm{D}) H=20 \mathrm{~m}$, E) $H=25 \mathrm{~m}$. 


\begin{tabular}{|c|c|c|c|c|c|c|}
\hline \multirow{4}{*}{ Impact Factor: } & ISRA (India) & $=3.117$ & SIS (USA) & $=0.912$ & ICV (Poland) & $=6.630$ \\
\hline & ISI (Dubai, UAE & $=0.829$ & РИНЦ (Russia & $=0.156$ & PIF (India) & $=1.940$ \\
\hline & GIF (Australia) & $=0.564$ & ESJI (KZ) & $=\mathbf{5 . 0 1 5}$ & IBI (India) & $=4.260$ \\
\hline & JIF & $=1.500$ & SJIF (Morocco & $=5.667$ & & \\
\hline
\end{tabular}

A
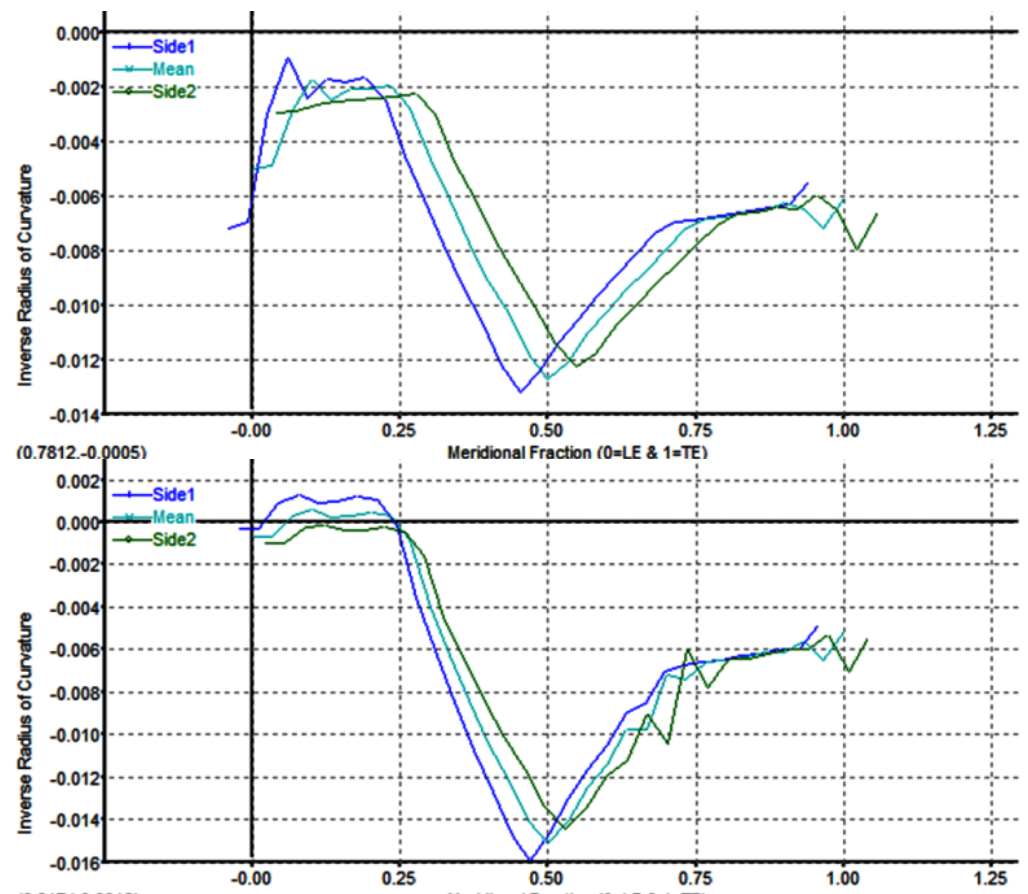

C

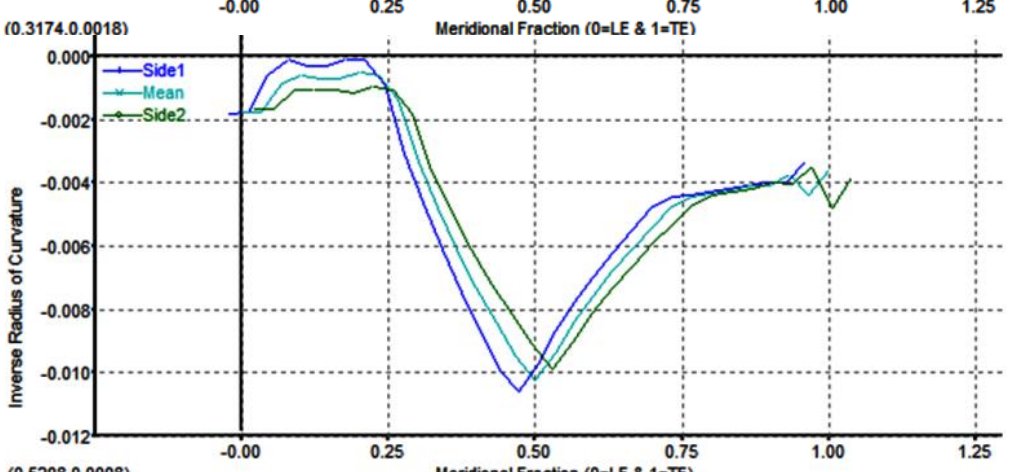

D
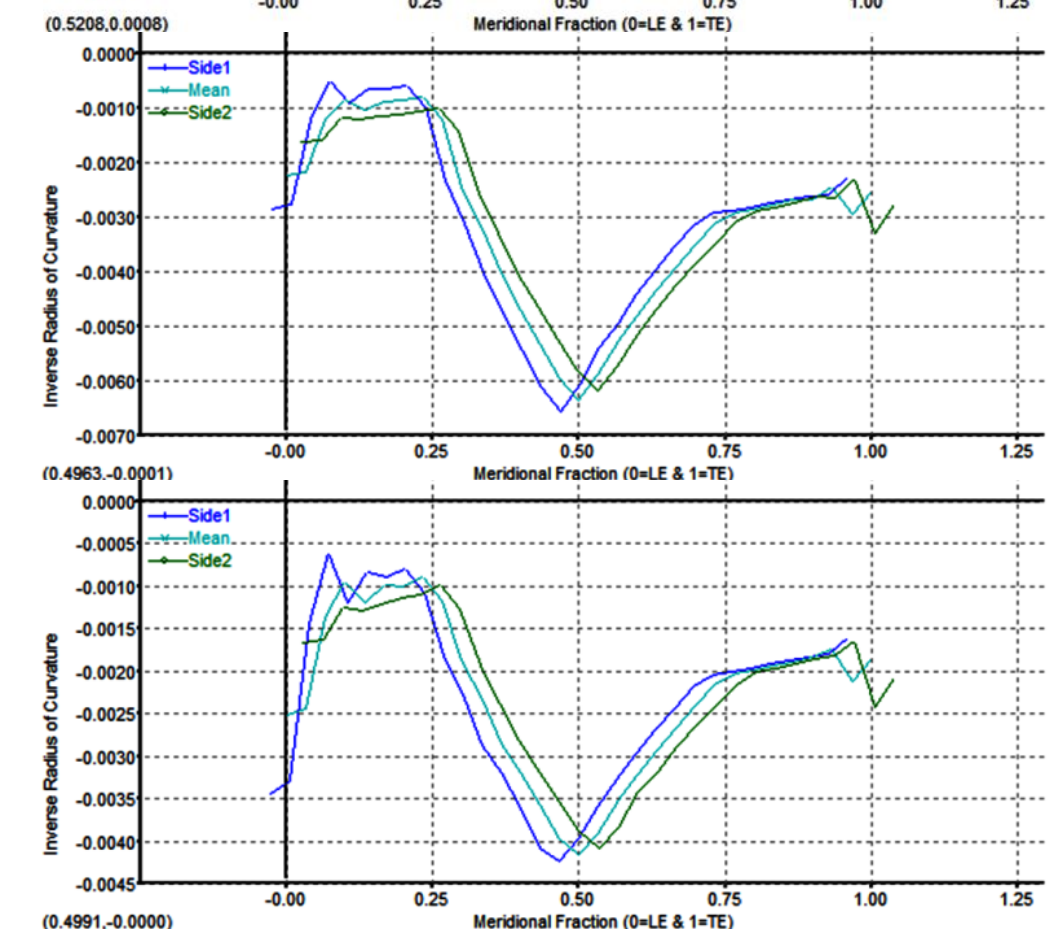

Figure 20 - The blade-to-blade curvature graph: A) $H=5 \mathrm{~m}, \mathrm{~B}) H=10 \mathrm{~m}, \mathrm{C}) H=15 \mathrm{~m}, \mathrm{D}) H=20 \mathrm{~m}$, E) $H=25 \mathrm{~m}$. 


\begin{tabular}{|c|c|c|c|c|c|c|}
\hline \multirow{4}{*}{ Impact Factor: } & ISRA (India) & $=3.117$ & SIS (USA) & $=0.912$ & ICV (Poland) & $=6.630$ \\
\hline & ISI (Dubai, UAE & $=0.829$ & РИНЦ (Russia) & $=0.156$ & PIF (India) & $=1.940$ \\
\hline & GIF (Australia) & $=0.564$ & ESJI (KZ) & $=\mathbf{5 . 0 1 5}$ & IBI (India) & $=4.260$ \\
\hline & JIF & $=1.500$ & SJIF (Morocco) & $=5.667$ & & \\
\hline
\end{tabular}

A
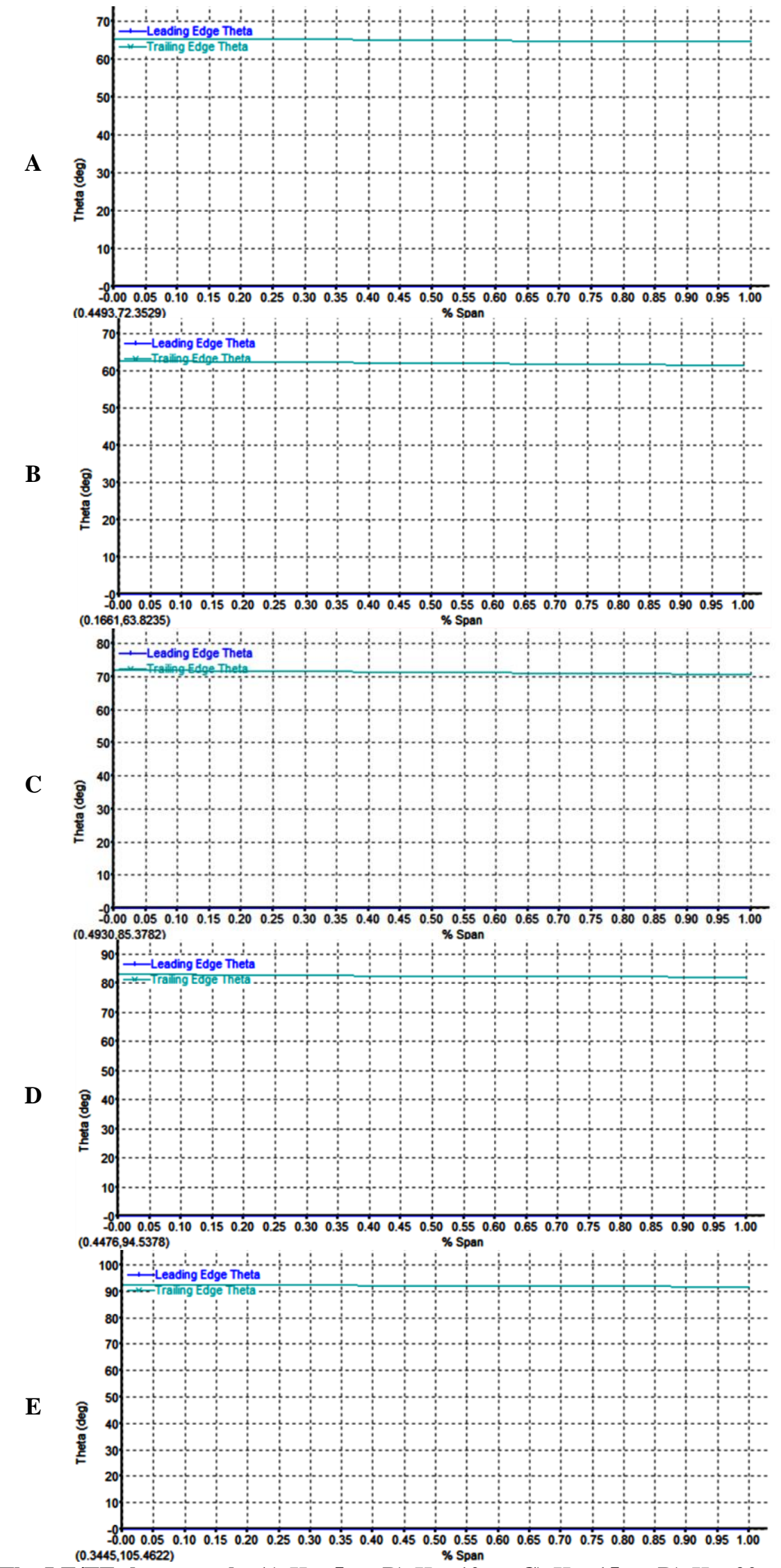

Figure 21 - The LE/TE theta graph: A) $H=5 \mathrm{~m}, \mathrm{~B}) H=10 \mathrm{~m}, \mathrm{C}) H=15 \mathrm{~m}, \mathrm{D}) H=20 \mathrm{~m}, \mathrm{E}) H=25 \mathrm{~m}$. 


\begin{tabular}{|c|c|c|c|c|c|c|}
\hline \multirow{4}{*}{ Impact Factor: } & ISRA (India) & $=3.117$ & SIS (USA) & $=0.912$ & ICV (Poland) & $=6.630$ \\
\hline & ISI (Dubai, UAE & $=0.829$ & РИНЦ (Russia) & $=0.156$ & PIF (India) & $=1.940$ \\
\hline & GIF (Australia) & $=0.564$ & ESJI (KZ) & $=\mathbf{5 . 0 1 5}$ & IBI (India) & $=4.260$ \\
\hline & JIF & $=1.500$ & SJIF (Morocco) & $=5.667$ & & \\
\hline
\end{tabular}

A
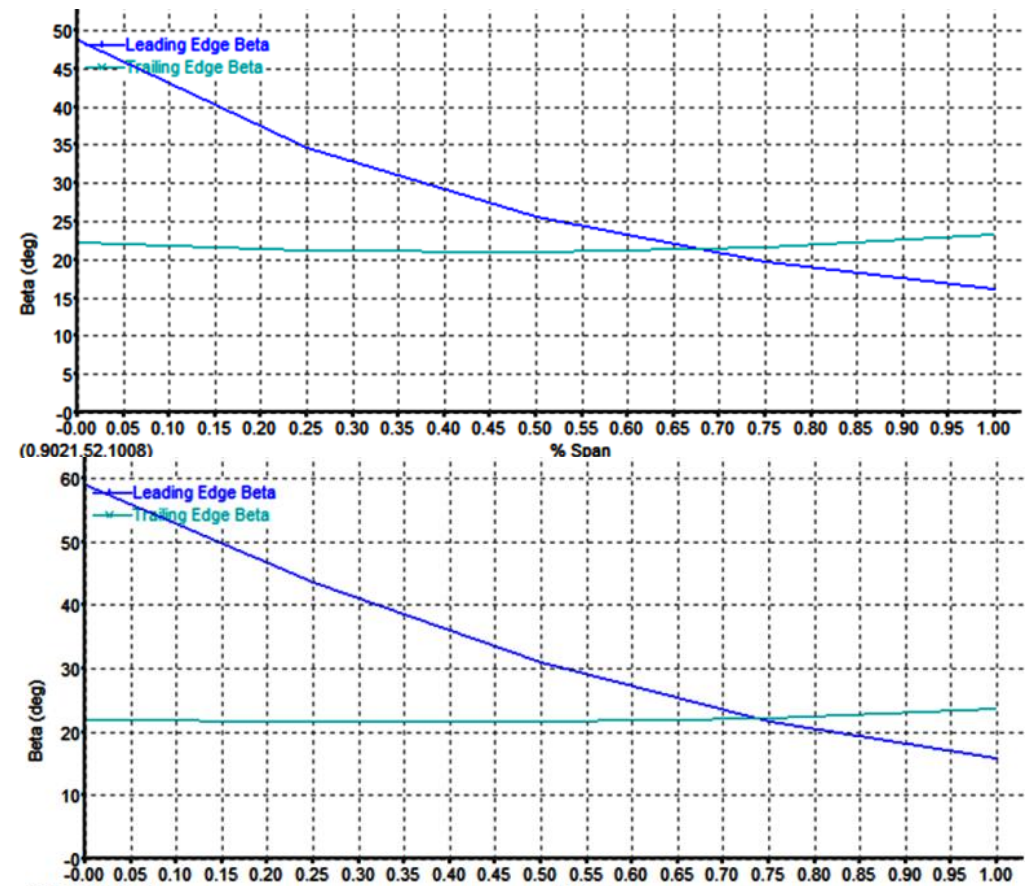

$\begin{array}{lllllllllllllllllllllll}-0.00 & 0.05 & 0.10 & 0.15 & 0.20 & 0.25 & 0.30 & 0.35 & 0.40 & 0.45 & 0.50 & 0.55 & 0.60 & 0.65 & 0.70 & 0.75 & 0.80 & 0.85 & 0.90 & 0.95 & 1.00\end{array}$ $(0.0455 .61 .7647)$ \% Span

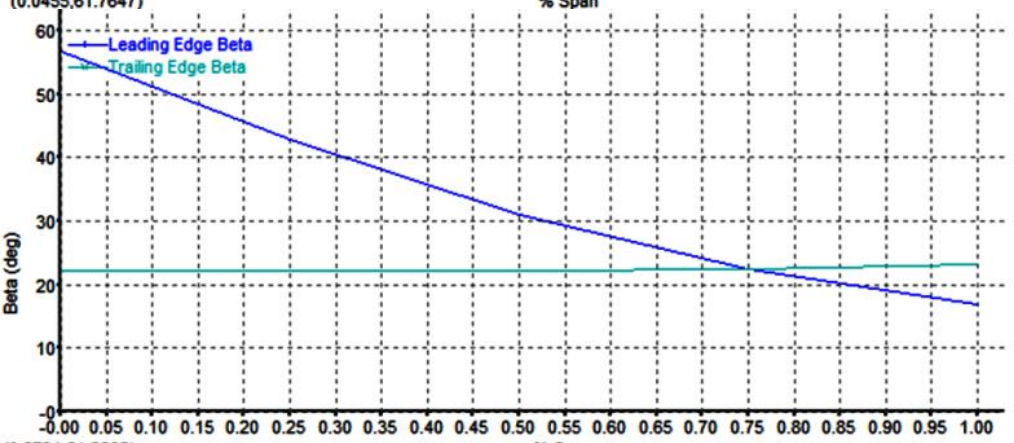

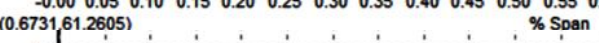

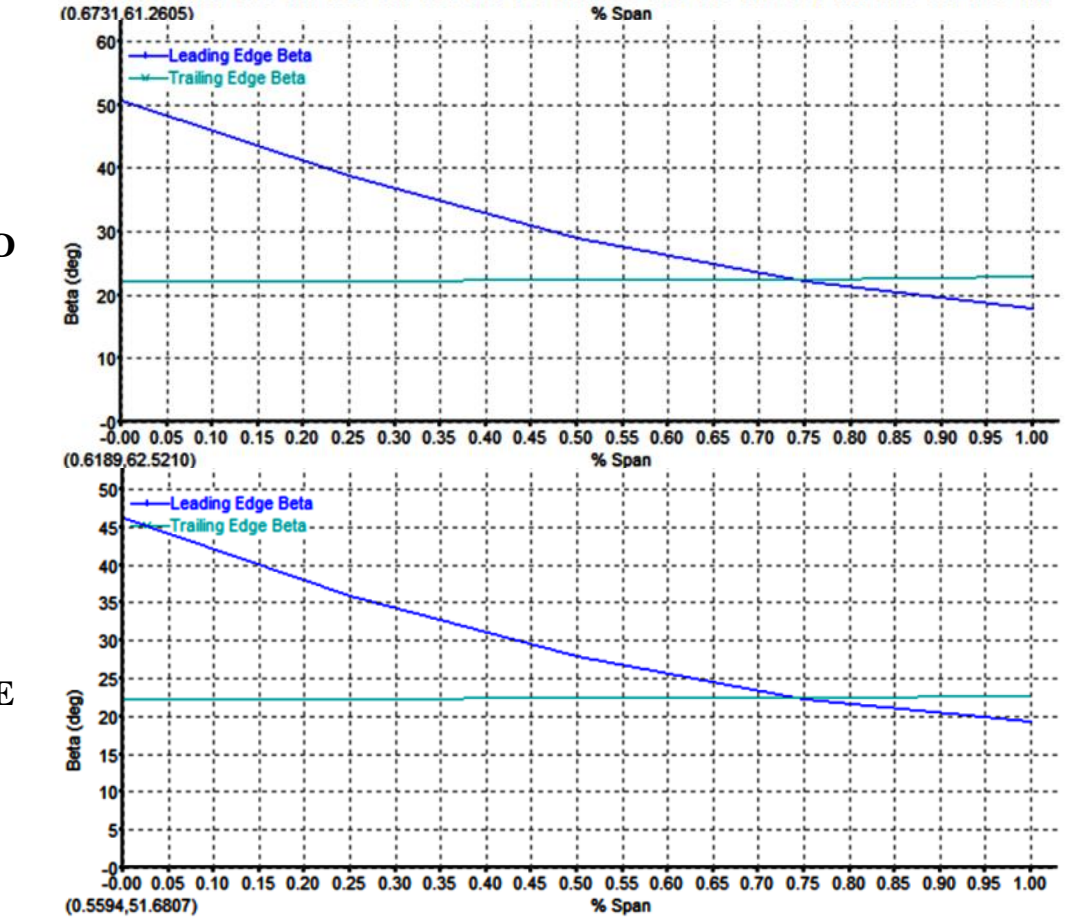

Figure 22 - The LE/TE beta graph: A) $H=5 \mathrm{~m}, \mathrm{~B}) H=10 \mathrm{~m}, \mathrm{C}) H=15 \mathrm{~m}, \mathrm{D}) H=20 \mathrm{~m}, \mathrm{E}) H=25 \mathrm{~m}$. 


\begin{tabular}{|c|c|c|c|c|c|c|}
\hline \multirow{4}{*}{ Impact Factor: } & ISRA (India) & $=3.117$ & SIS (USA) & $=0.912$ & ICV (Poland) & $=6.630$ \\
\hline & ISI (Dubai, UAE & $=0.829$ & РИНЦ (Russia) & $=0.156$ & PIF (India) & $=1.940$ \\
\hline & GIF (Australia) & $=0.564$ & ESJI (KZ) & $=\mathbf{5 . 0 1 5}$ & IBI (India) & $=4.260$ \\
\hline & JIF & $=1.500$ & SJIF (Morocco) & $=5.667$ & & \\
\hline
\end{tabular}

A

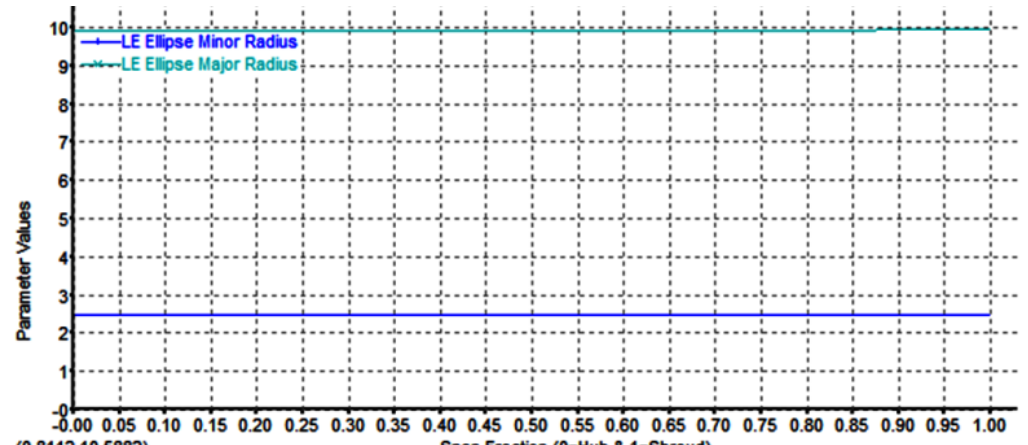
(0.8112.10.5882)

Soan Fraction $(0=$ Hub \& $1=$ Shroud $)$

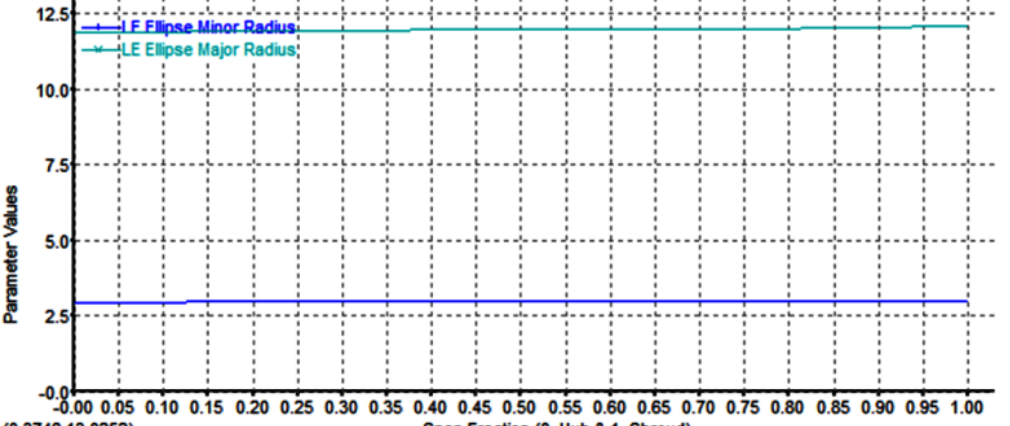

$\begin{array}{lllllllllllllllllllllll}-0.0 .00 & 0.05 & 0.10 & 0.15 & 0.20 & 0.25 & 0.30 & 0.35 & 0.40 & 0.45 & 0.50 & 0.55 & 0.60 & 0.65 & 0.70 & 0.75 & 0.80 & 0.85 & 0.90 & 0.95 & 1.00\end{array}$ $(0.3748,13.0252)$ Span Fraction ( $0=$ Hub \& $1=$ Shroud)

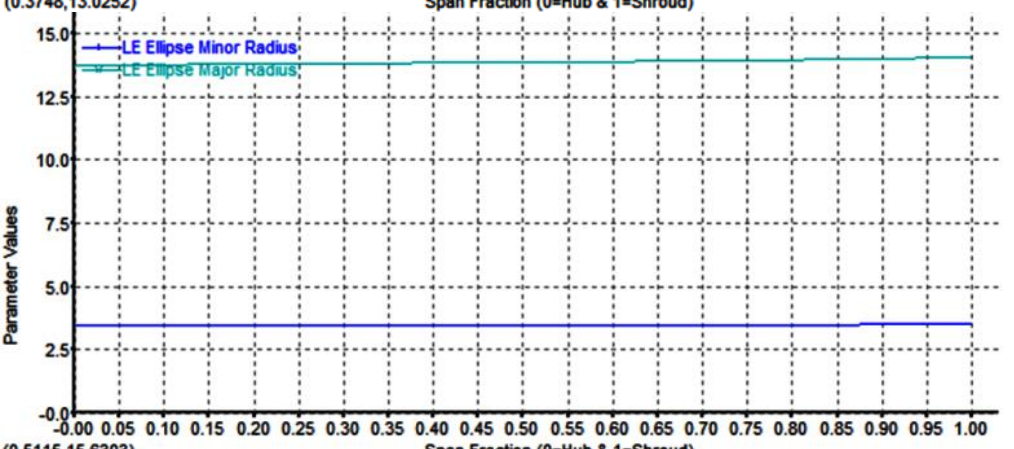
$(0.5115,15.6303)$

Span Fraction $(0=$ Hub \& $1=$ Shroud $)$
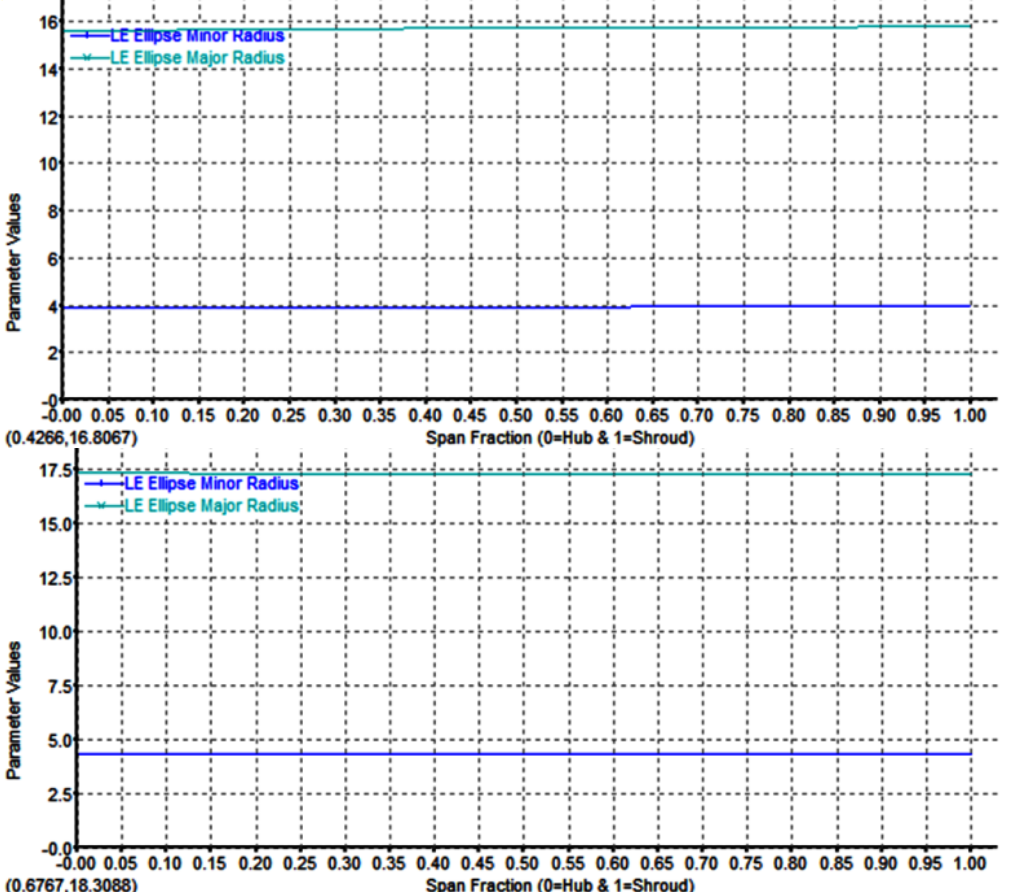

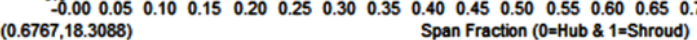

Figure 23 - The LE/TE parameter graph: A) $H=5 \mathrm{~m}, \mathrm{~B}) H=10 \mathrm{~m}, \mathrm{C}) H=15 \mathrm{~m}, \mathrm{D}) H=20 \mathrm{~m}, \mathrm{E}) H=25 \mathrm{~m}$. 


\begin{tabular}{|c|c|c|c|c|c|c|}
\hline \multirow{4}{*}{ Impact Factor: } & ISRA (India) & $=3.117$ & SIS (USA) & $=0.912$ & ICV (Poland) & $=6.630$ \\
\hline & ISI (Dubai, UAE & $=0.829$ & РИНЦ (Russia) & $=0.156$ & PIF (India) & $=1.940$ \\
\hline & GIF (Australia) & $=0.564$ & ESJI (KZ) & $=5.015$ & IBI (India) & $=4.260$ \\
\hline & JIF & $=1.500$ & SJIF (Morocco) & $=5.667$ & & \\
\hline
\end{tabular}

A
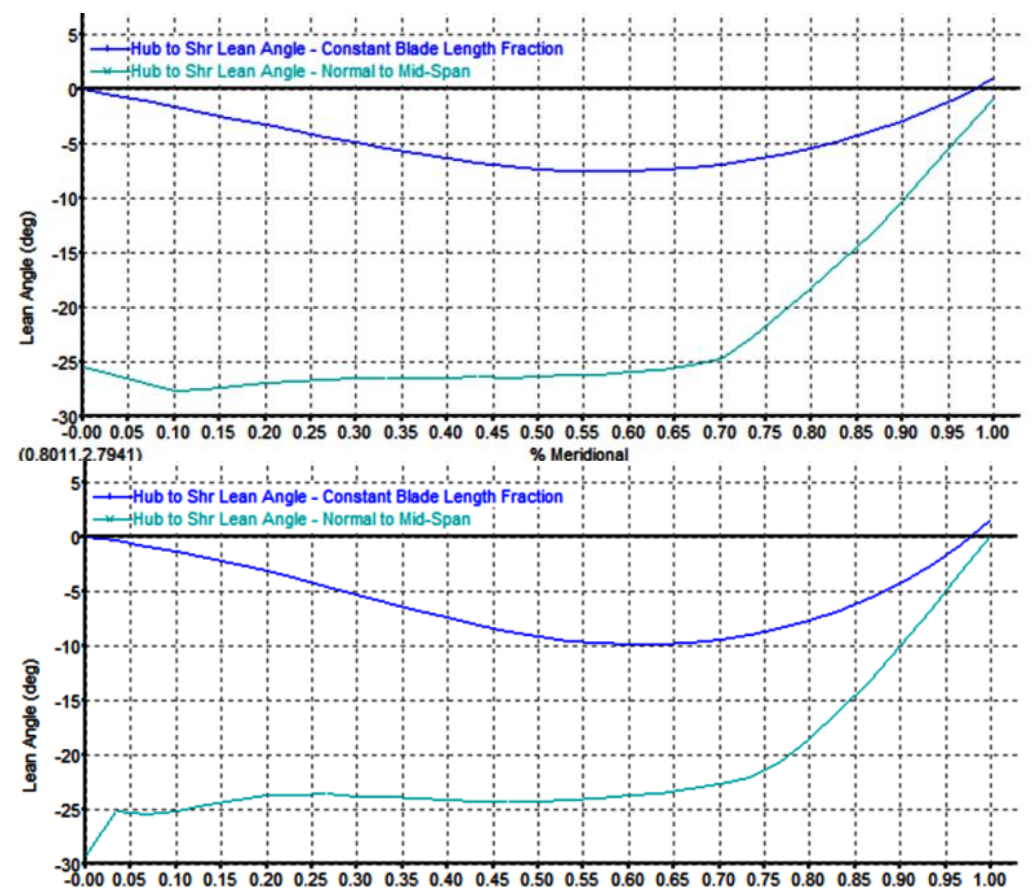
(0.2095.1.3235)
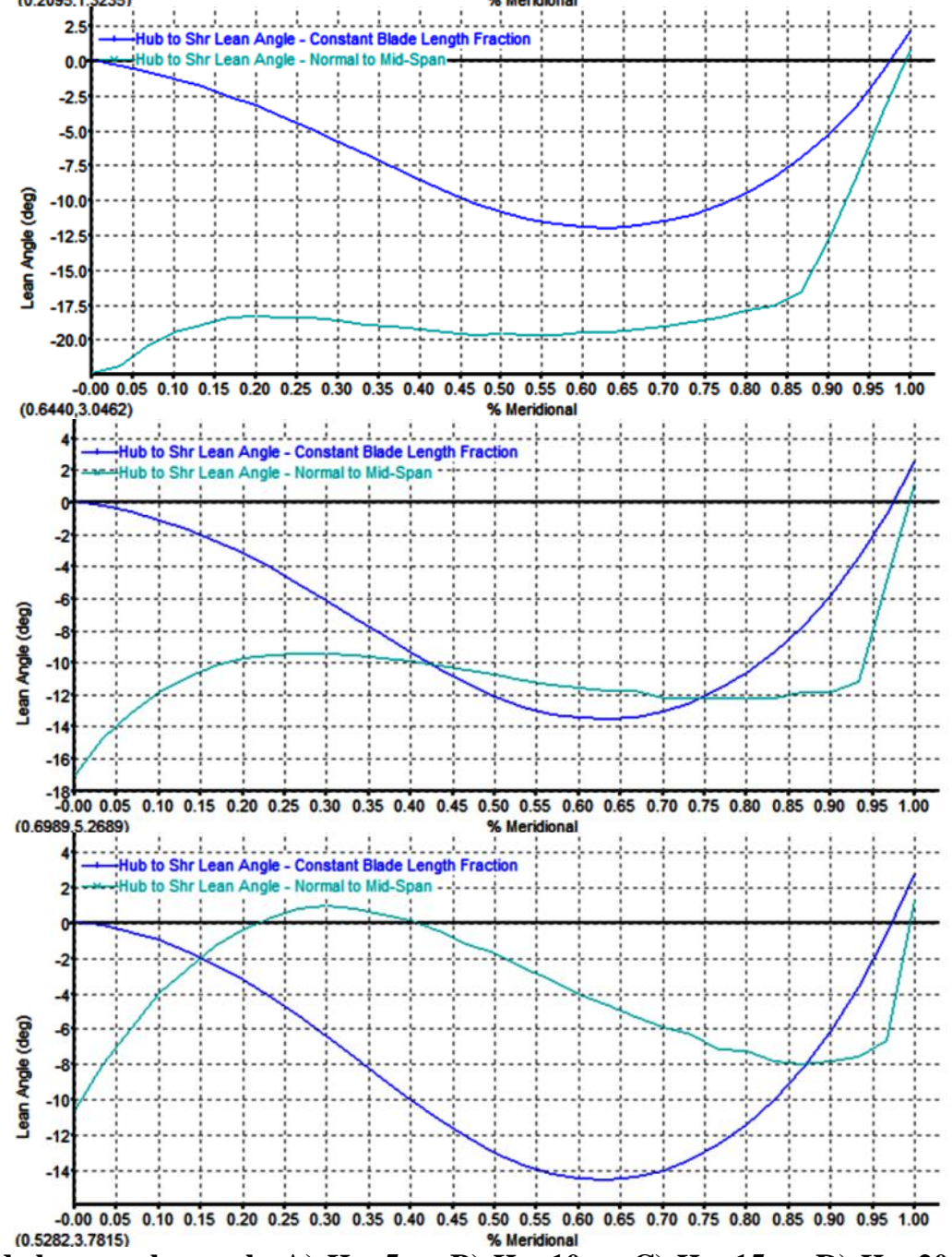

Figure 24 - The blade lean angle graph: A) $H=5 \mathrm{~m}, \mathrm{~B}) H=10 \mathrm{~m}, \mathrm{C}) H=15 \mathrm{~m}, \mathrm{D}) H=20 \mathrm{~m}, \mathrm{E}) H=25 \mathrm{~m}$. 


\begin{tabular}{|c|c|c|c|c|c|c|}
\hline \multirow{4}{*}{ Impact Factor: } & ISRA (India) & $=3.117$ & SIS (USA) & $=0.912$ & ICV (Poland) & $=6.630$ \\
\hline & ISI (Dubai, UAE & $=0.829$ & РИНЦ (Russia) & $=0.156$ & PIF (India) & $=1.940$ \\
\hline & GIF (Australia) & $=0.564$ & ESJI (KZ) & $=\mathbf{5 . 0 1 5}$ & IBI (India) & $=4.260$ \\
\hline & JIF & $=1.500$ & SJIF (Morocco) & $=5.667$ & & \\
\hline
\end{tabular}

A

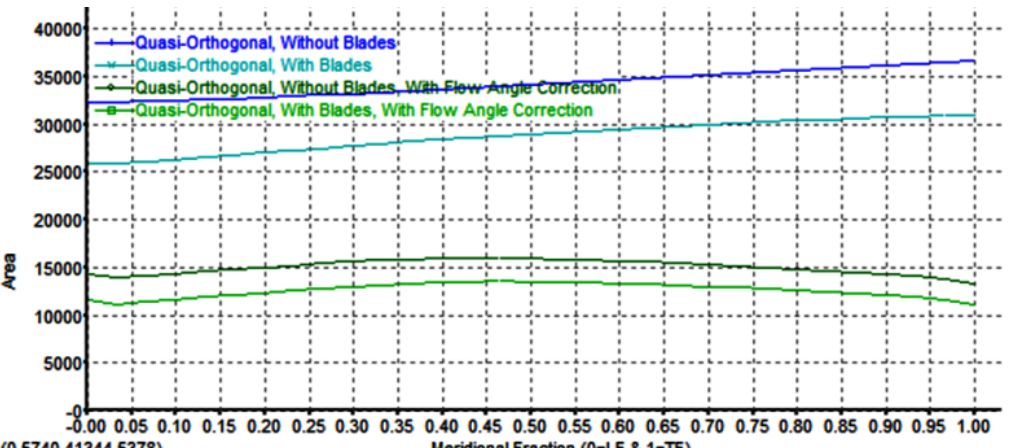

(0.5740.41344.5378) Meridional Fraction ( $0=L \mathrm{LE} \& 1=\mathrm{TE})$
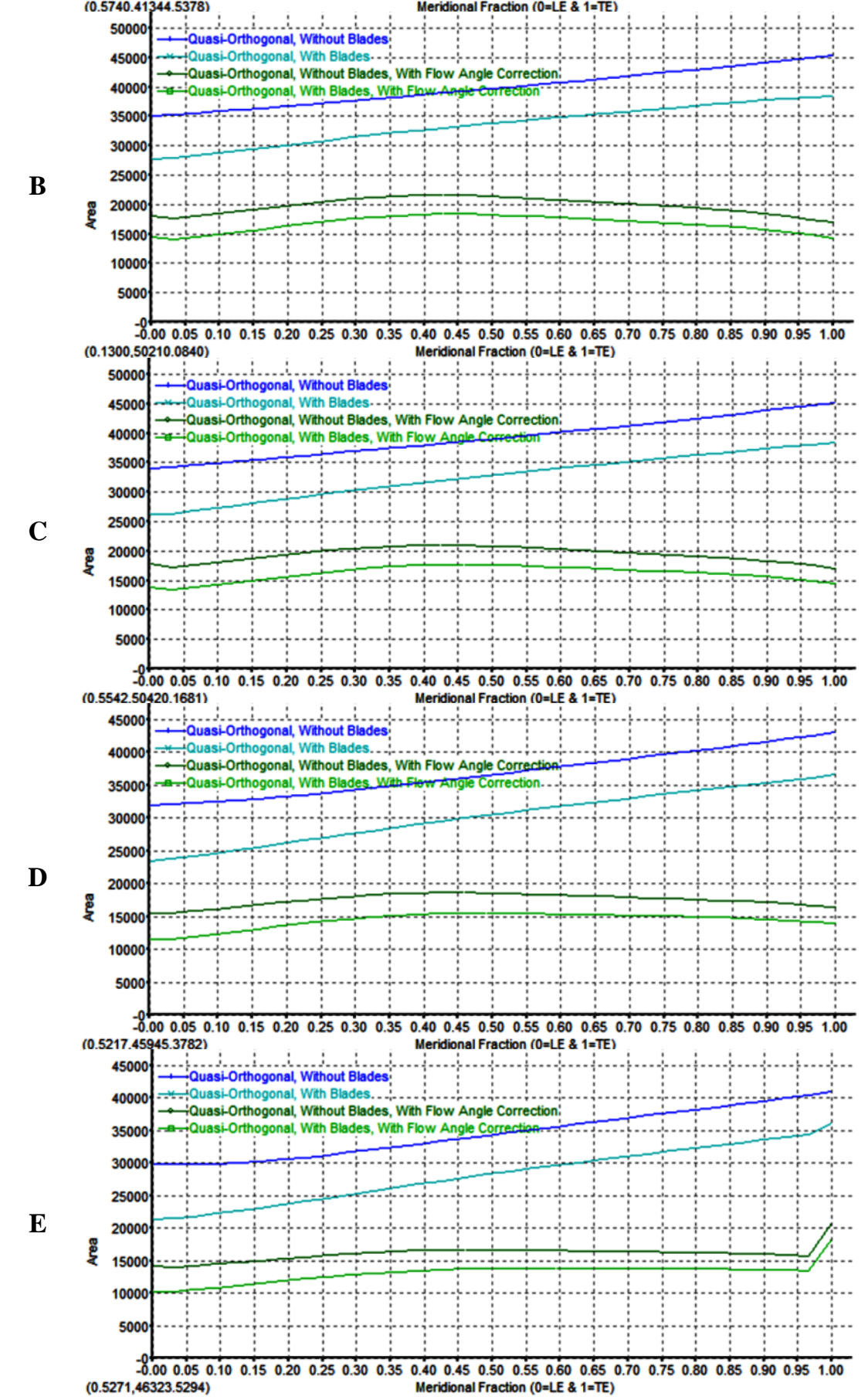

Figure 25 - The quasi-orthogonal area graph: A) $H=5 \mathrm{~m}, \mathrm{~B}) H=10 \mathrm{~m}, \mathrm{C}) H=15 \mathrm{~m}, \mathrm{D}) H=20 \mathrm{~m}$, E) $H=25 \mathrm{~m}$. 


\begin{tabular}{|c|c|c|c|c|c|c|}
\hline \multirow{4}{*}{ Impact Factor: } & ISRA (India) & $=3.117$ & SIS (USA) & $=0.912$ & ICV (Poland) & $=6.630$ \\
\hline & ISI (Dubai, UAE & $=0.829$ & РИНЦ (Russia) & $=0.156$ & PIF (India) & $=1.940$ \\
\hline & GIF (Australia) & $=0.564$ & ESJI (KZ) & $=5.015$ & IBI (India) & $=4.260$ \\
\hline & JIF & $=1.500$ & SJIF (Morocco) & $=5.667$ & & \\
\hline
\end{tabular}

A

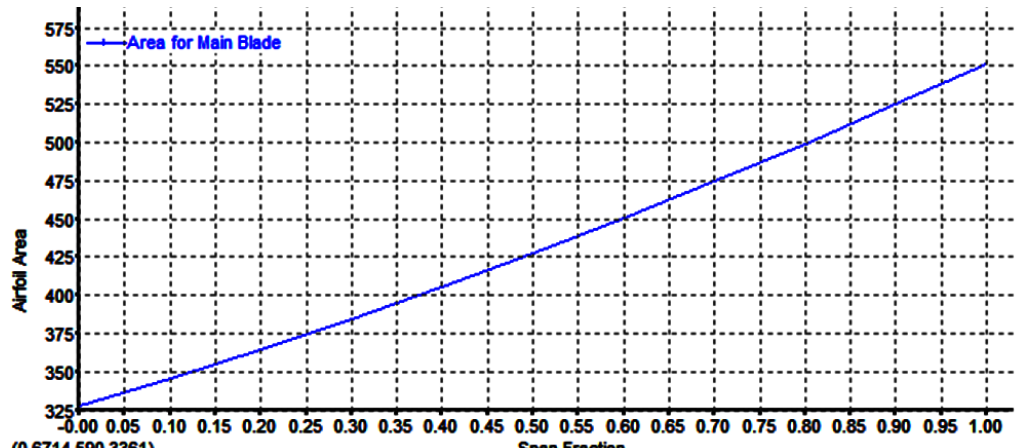

$(0.6714 .590 .3361)$

Soan Fraction

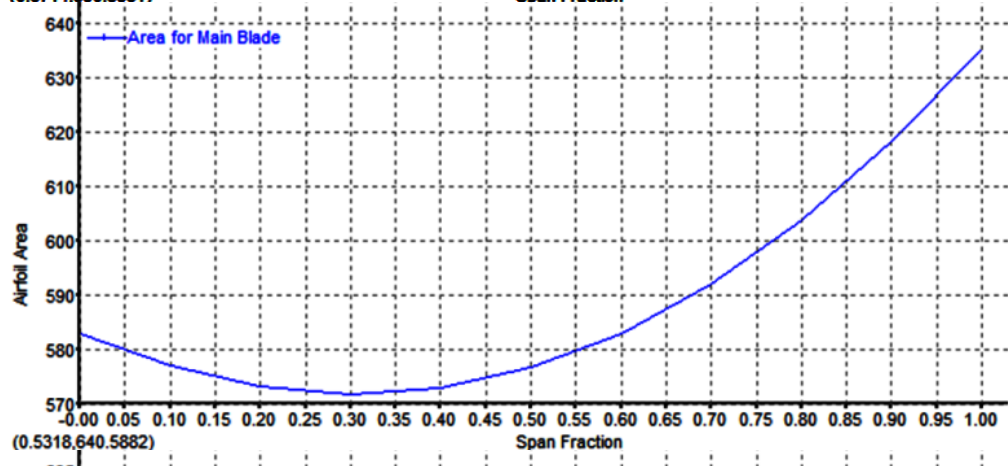

B

C
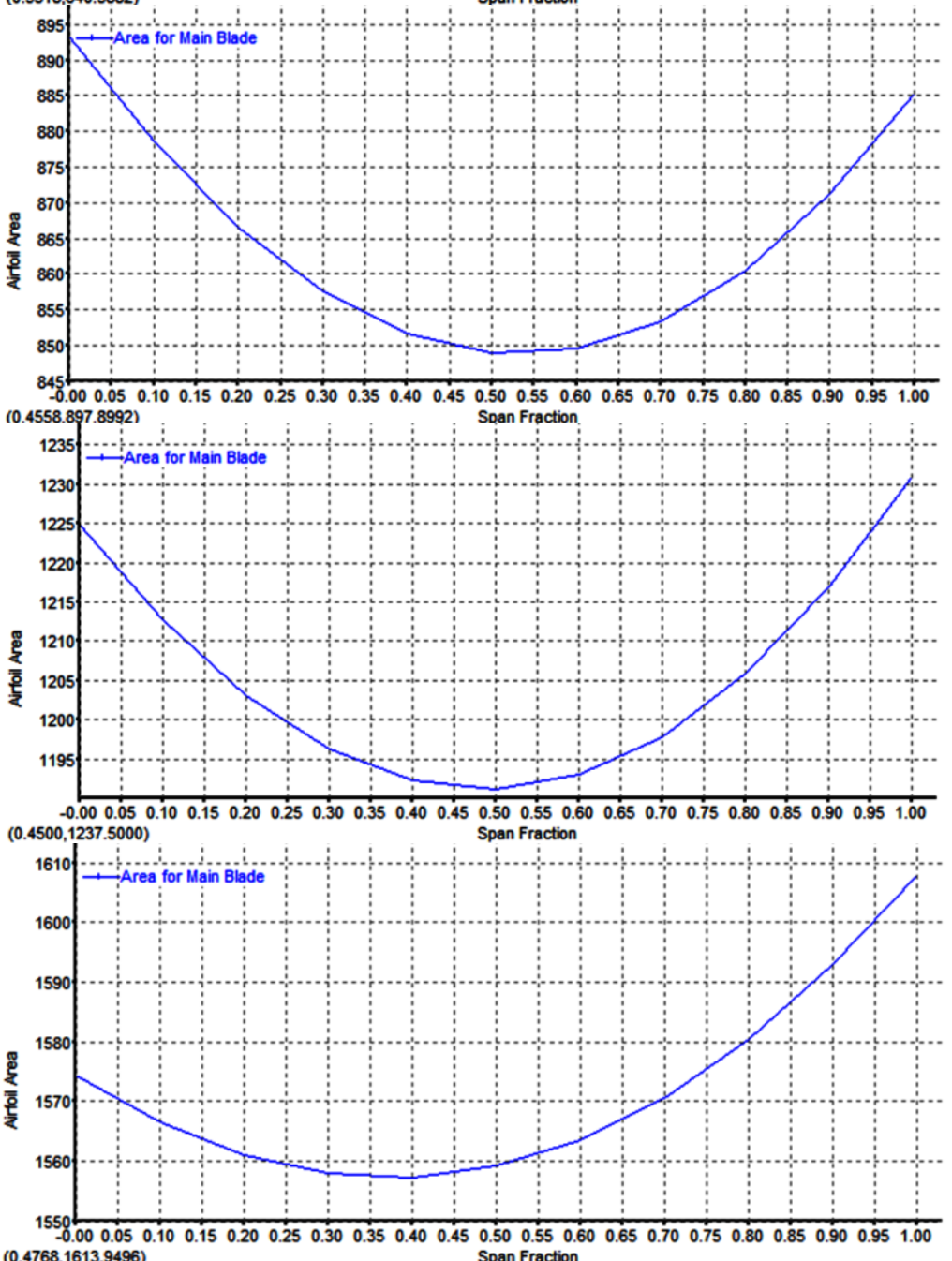

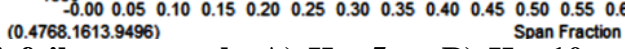

Figure 26 - The airfoil area graph: A) $H=5 \mathrm{~m}, \mathrm{~B}) H=10 \mathrm{~m}, \mathrm{C}) H=15 \mathrm{~m}, \mathrm{D}) H=20 \mathrm{~m}, \mathrm{E}) H=25 \mathrm{~m}$. 


\begin{tabular}{|c|c|c|c|c|c|c|}
\hline \multirow{4}{*}{ Impact Factor: } & ISRA (India) & $=3.117$ & SIS (USA) & $=0.912$ & ICV (Poland) & $=6.630$ \\
\hline & ISI (Dubai, UAE & $=0.829$ & РИНЦ (Russia) & $=0.156$ & PIF (India) & $=1.940$ \\
\hline & GIF (Australia) & $=0.564$ & ESJI (KZ) & $=5.015$ & IBI (India) & $=4.260$ \\
\hline & JIF & $=1.500$ & SJIF (Morocco) & $=5.667$ & & \\
\hline
\end{tabular}

A
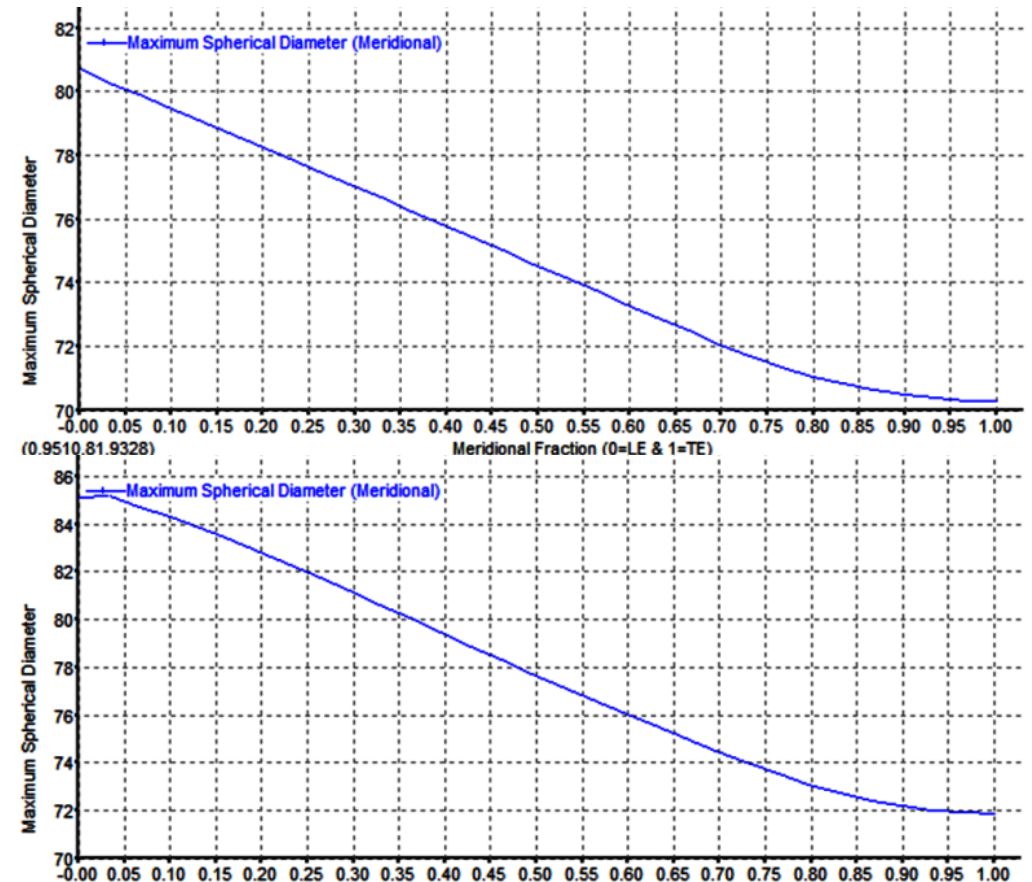

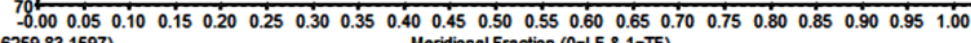
0.6259.83.1597) Meridional Fraction ( $0=L E \&$ \& $1=T E)$
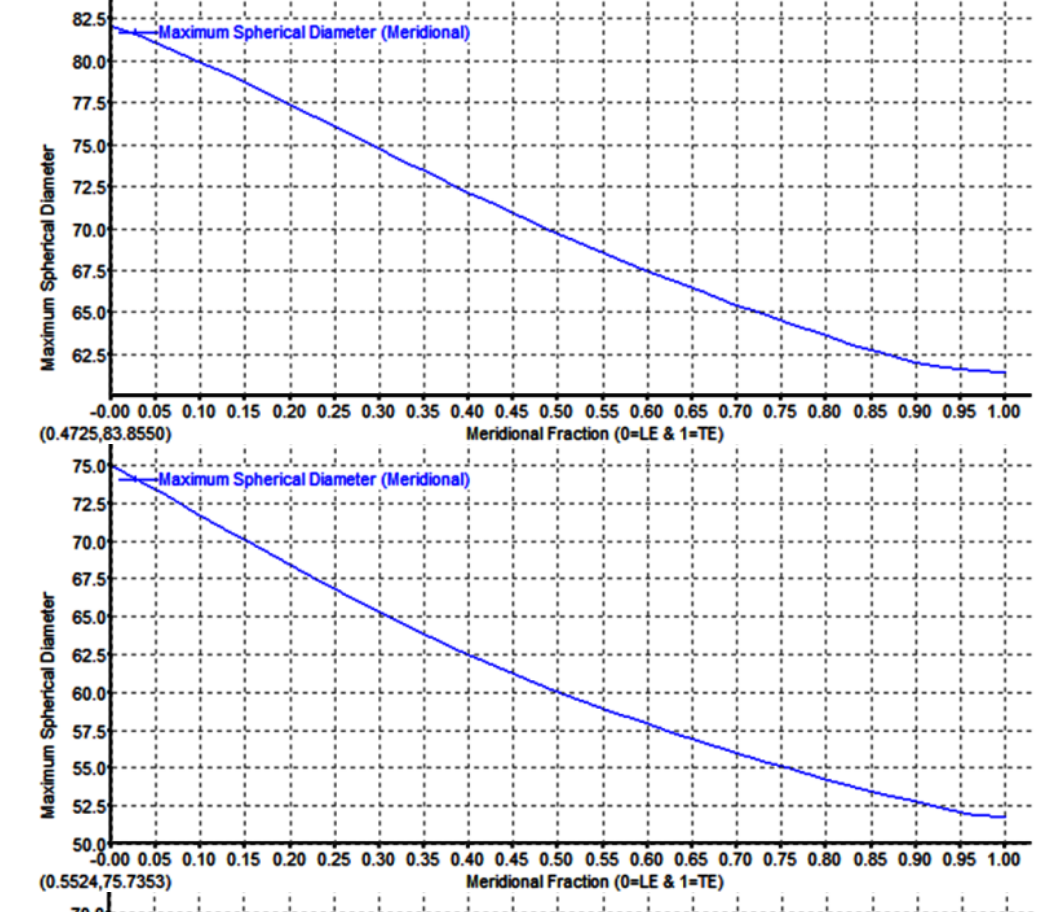

D

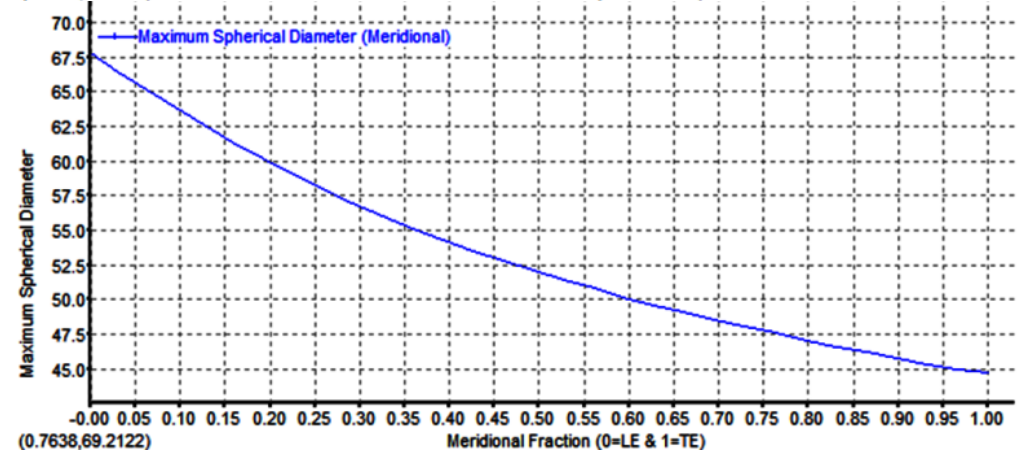

Figure 27 - The maximum diameter graph: A) $H=5 \mathrm{~m}, \mathrm{~B}) H=10 \mathrm{~m}, \mathrm{C}) H=15 \mathrm{~m}, \mathrm{D}) H=20 \mathrm{~m}$, E) $H=25 \mathrm{~m}$. 


\begin{tabular}{|c|c|c|c|c|c|c|}
\hline \multirow{4}{*}{ Impact Factor: } & ISRA (India) & $=3.117$ & SIS (USA) & $=0.912$ & ICV (Poland) & $=6.630$ \\
\hline & ISI (Dubai, UAE & $=0.829$ & РИНЦ (Russia) & $=0.156$ & PIF (India) & $=1.940$ \\
\hline & GIF (Australia) & $=0.564$ & ESJI (KZ) & $=\mathbf{5 . 0 1 5}$ & IBI (India) & $=4.260$ \\
\hline & JIF & $=1.500$ & SJIF (Morocco) & $=5.667$ & & \\
\hline
\end{tabular}

A
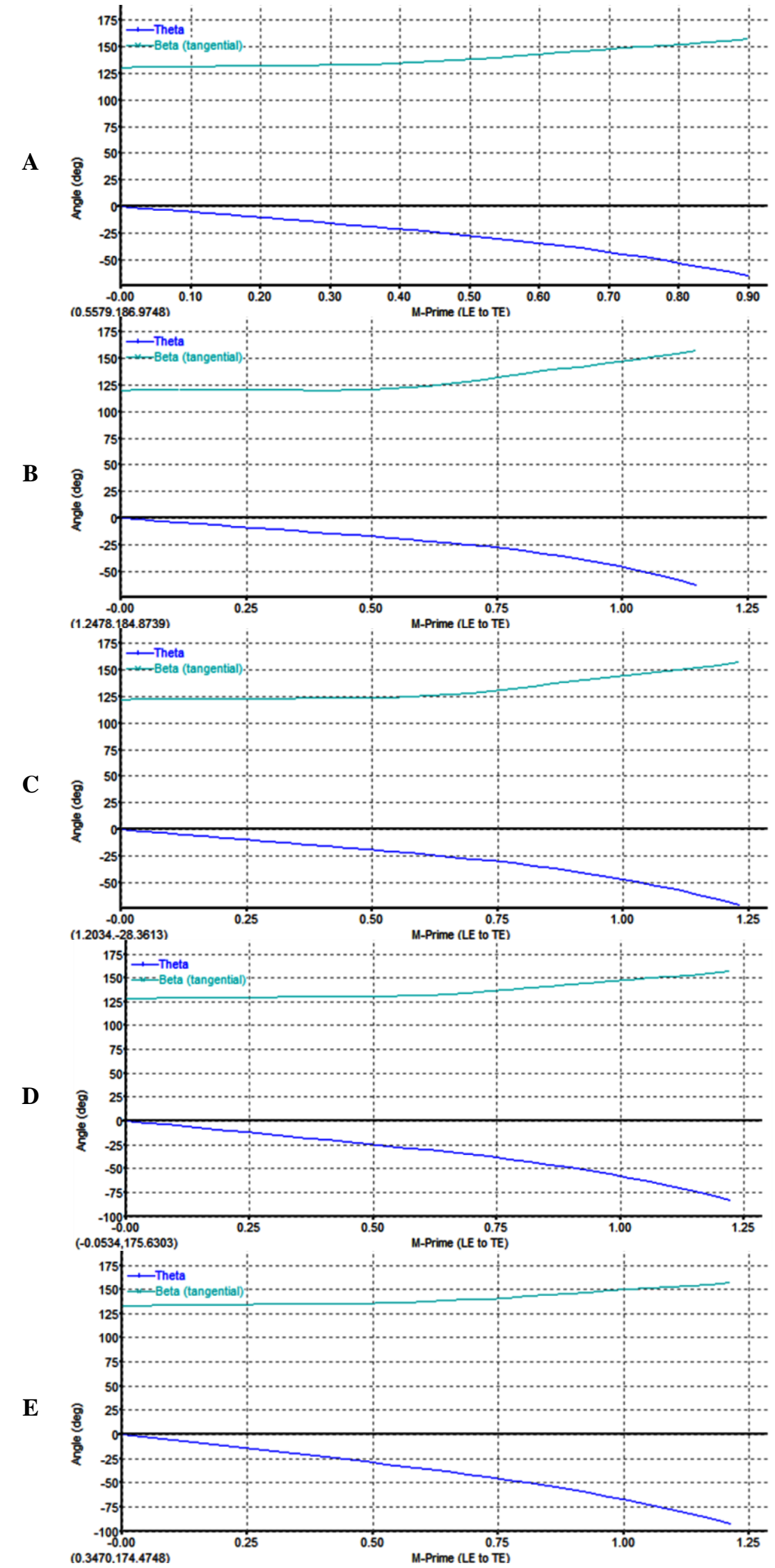

Figure 28 - The blade angle graph vs. M-prime position: A) $H=5 \mathrm{~m}, \mathrm{~B}) H=10 \mathrm{~m}, \mathrm{C}) H=15 \mathrm{~m}$, D) $H=20 \mathrm{~m}$, E) $H=25 \mathrm{~m}$. 


\begin{tabular}{|c|c|c|c|c|c|c|}
\hline \multirow{4}{*}{ Impact Factor: } & ISRA (India) & $=3.117$ & SIS (USA) & $=0.912$ & ICV (Poland) & $=6.630$ \\
\hline & ISI (Dubai, UAE & $=0.829$ & РИНЦ (Russia) & $=0.156$ & PIF (India) & $=1.940$ \\
\hline & GIF (Australia) & $=0.564$ & ESJI (KZ) & $=\mathbf{5 . 0 1 5}$ & IBI (India) & $=4.260$ \\
\hline & JIF & $=1.500$ & SJIF (Morocco) & $=5.667$ & & \\
\hline
\end{tabular}

A
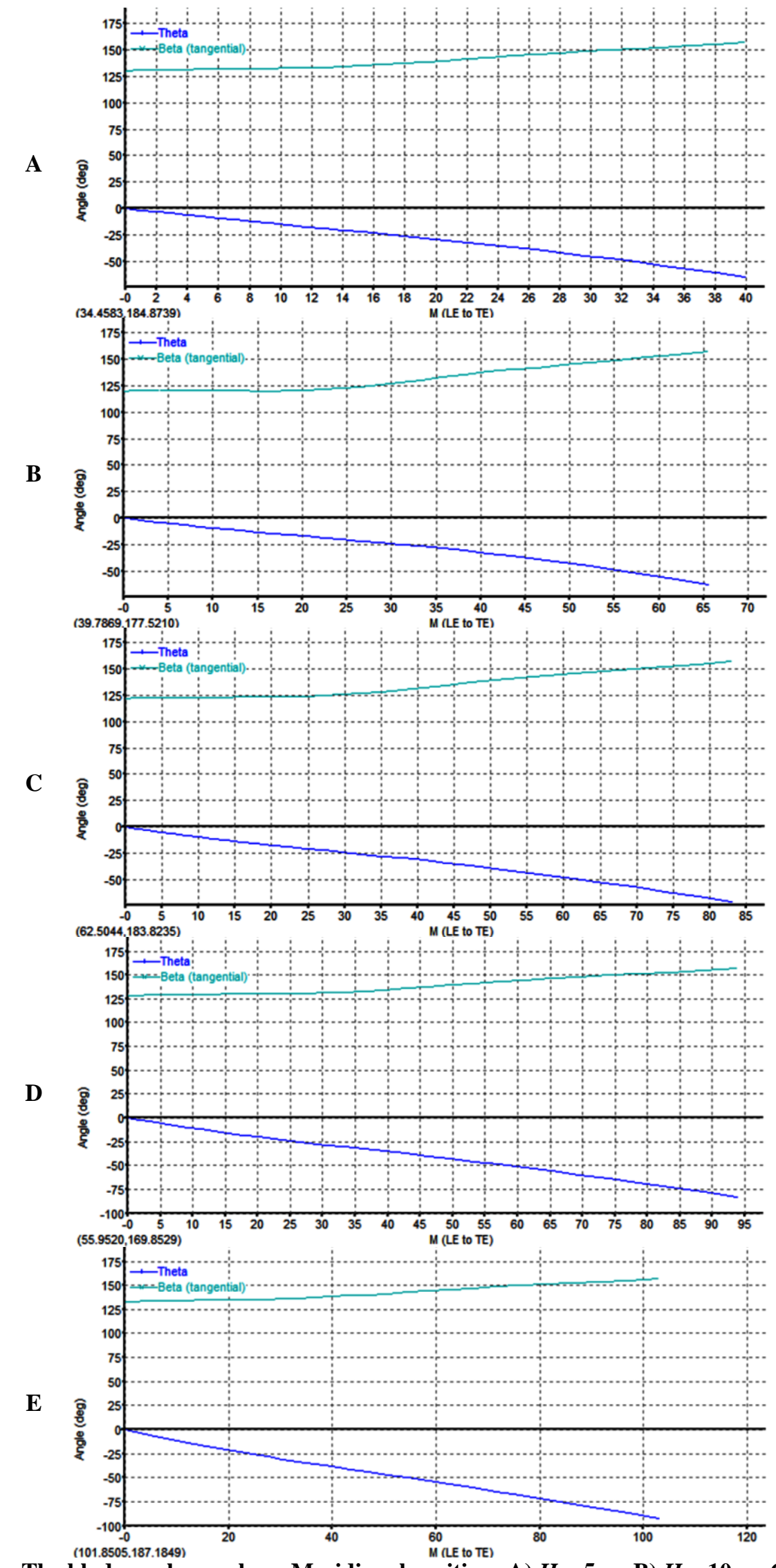

Figure 29 - The blade angle graph vs. Meridional position: A) $H=5 \mathrm{~m}, \mathrm{~B}) H=10 \mathrm{~m}, \mathrm{C}) H=15 \mathrm{~m}$, D) $H=20 \mathrm{~m}$, E) $H=25 \mathrm{~m}$. 


\begin{tabular}{|c|c|c|c|c|c|c|}
\hline \multirow{4}{*}{ Impact Factor: } & ISRA (India) & $=3.117$ & SIS (USA) & $=0.912$ & ICV (Poland) & $=6.630$ \\
\hline & ISI (Dubai, UAE & $=0.829$ & РИНЦ (Russia & $=0.156$ & PIF (India) & $=1.940$ \\
\hline & GIF (Australia) & $=0.564$ & ESJI (KZ) & $=5.015$ & IBI (India) & $=4.260$ \\
\hline & JIF & $=1.500$ & SJIF (Morocco & $=5.667$ & & \\
\hline
\end{tabular}

A
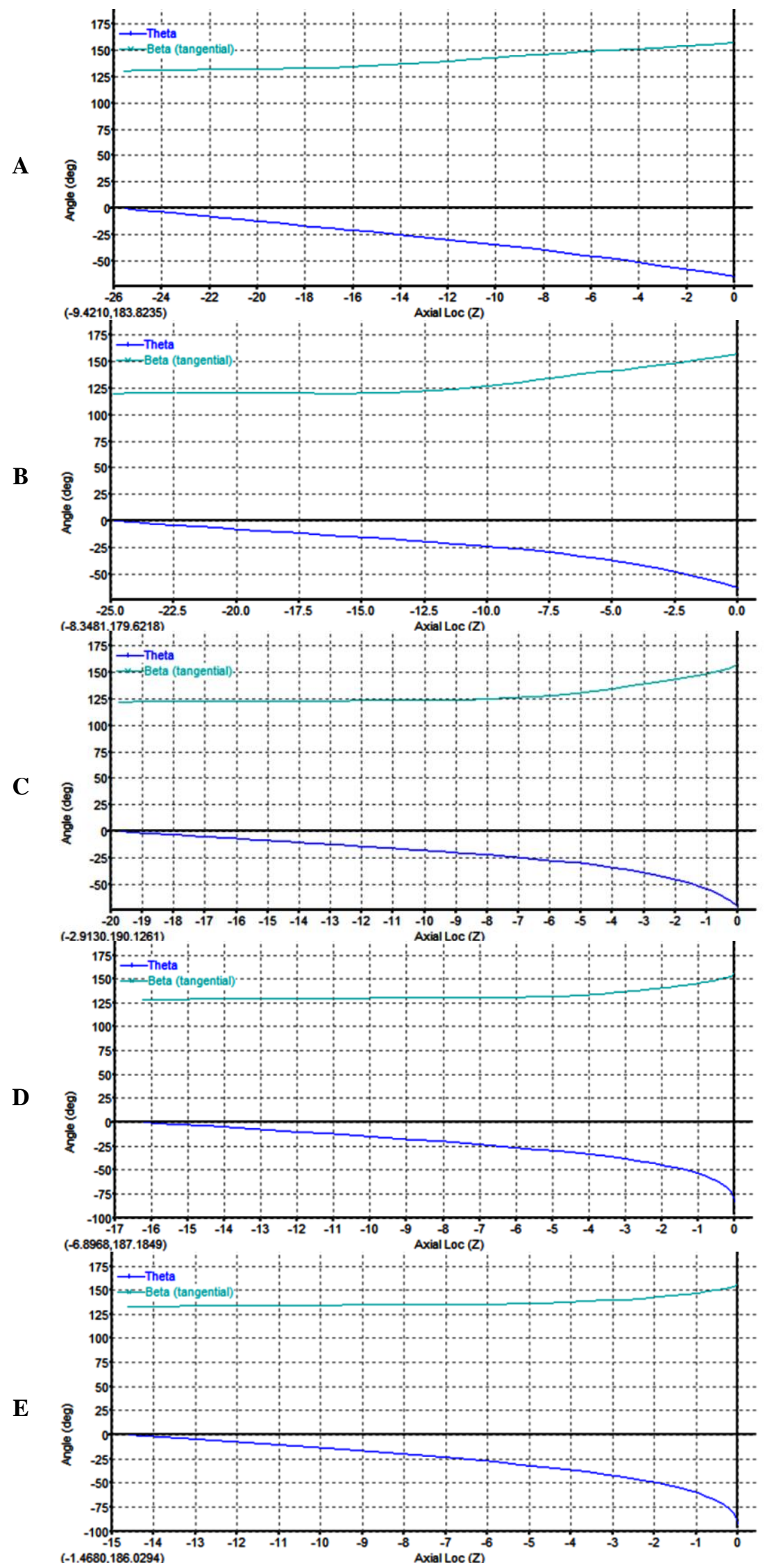

Figure 30 - The blade angle graph vs. Axial location $(Z)$ : A) $H=5 \mathrm{~m}, \mathrm{~B}) H=10 \mathrm{~m}, \mathrm{C}) H=15 \mathrm{~m}, \mathrm{D}) H=20 \mathrm{~m}$, E) $H=25 \mathrm{~m}$. 


\begin{tabular}{|c|c|c|c|c|c|c|}
\hline \multirow{4}{*}{ Impact Factor: } & ISRA (India) & $=3.117$ & SIS (USA) & $=0.912$ & ICV (Poland) & $=6.630$ \\
\hline & ISI (Dubai, UAE & $=0.829$ & РИНЦ (Russia) & $=0.156$ & PIF (India) & $=1.940$ \\
\hline & GIF (Australia) & $=0.564$ & ESJI (KZ) & $=5.015$ & IBI (India) & $=4.260$ \\
\hline & JIF & $=1.500$ & SJIF (Morocco) & $=5.667$ & & \\
\hline
\end{tabular}

A
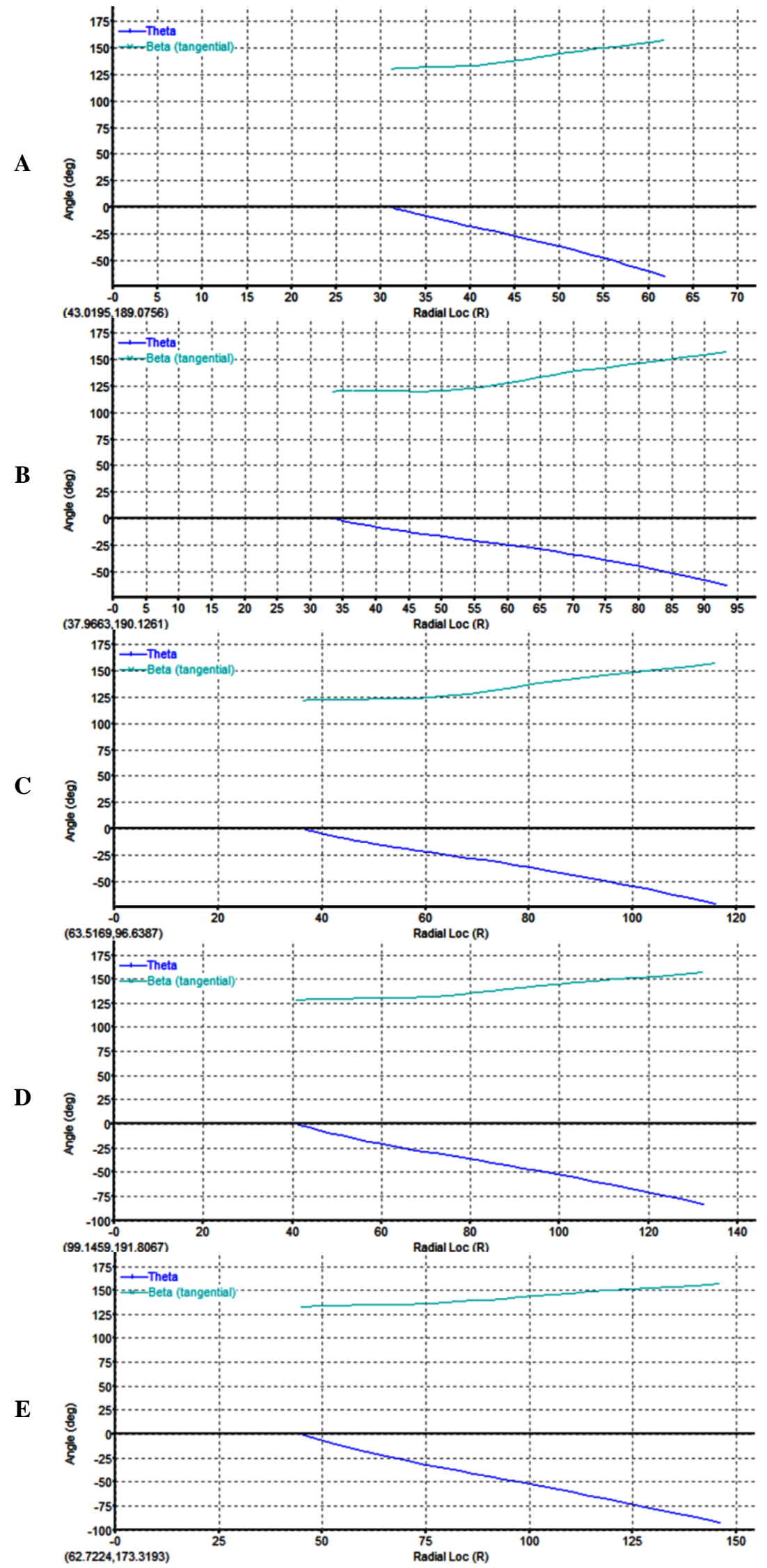

Figure 31 - The blade angle graph vs. Radial location $(R): A) H=5 \mathrm{~m}, \mathrm{~B}) H=10 \mathrm{~m}, \mathrm{C}) H=15 \mathrm{~m}$, D) $H=20 \mathrm{~m}, \mathrm{E}) H=25 \mathrm{~m}$. 


\begin{tabular}{|c|c|c|c|c|c|c|}
\hline \multirow{4}{*}{ Impact Factor: } & ISRA (India) & $=3.117$ & SIS (USA) & $=0.912$ & ICV (Poland) & $=6.630$ \\
\hline & ISI (Dubai, UAE & $=0.829$ & РИНЦ (Russia & $=0.156$ & PIF (India) & $=1.940$ \\
\hline & GIF (Australia) & $=0.564$ & ESJI (KZ) & $=\mathbf{5 . 0 1 5}$ & IBI (India) & $=4.260$ \\
\hline & JIF & $=1.500$ & SJIF (Morocco & $=5.667$ & & \\
\hline
\end{tabular}

A

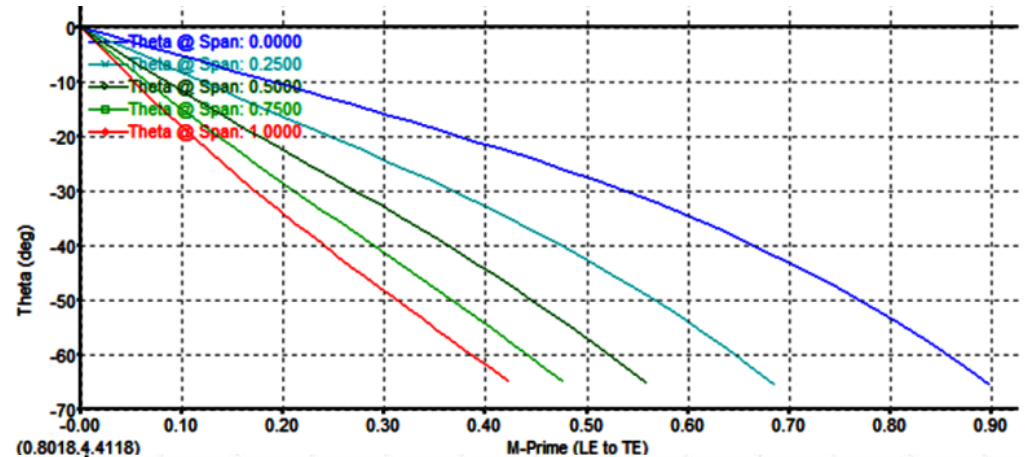

B

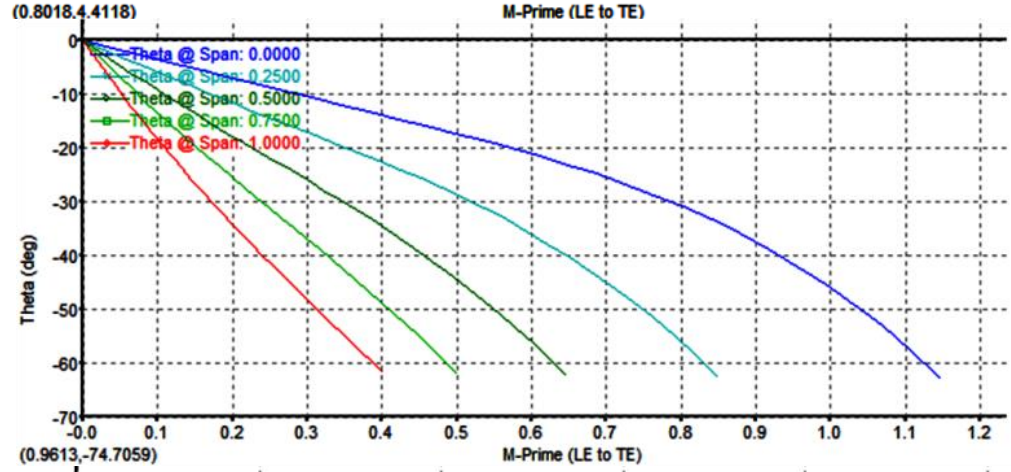

C

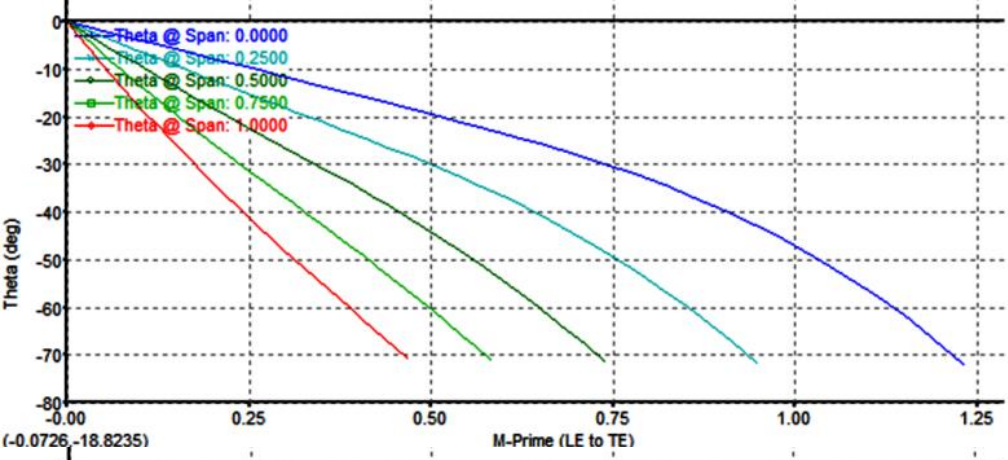

D
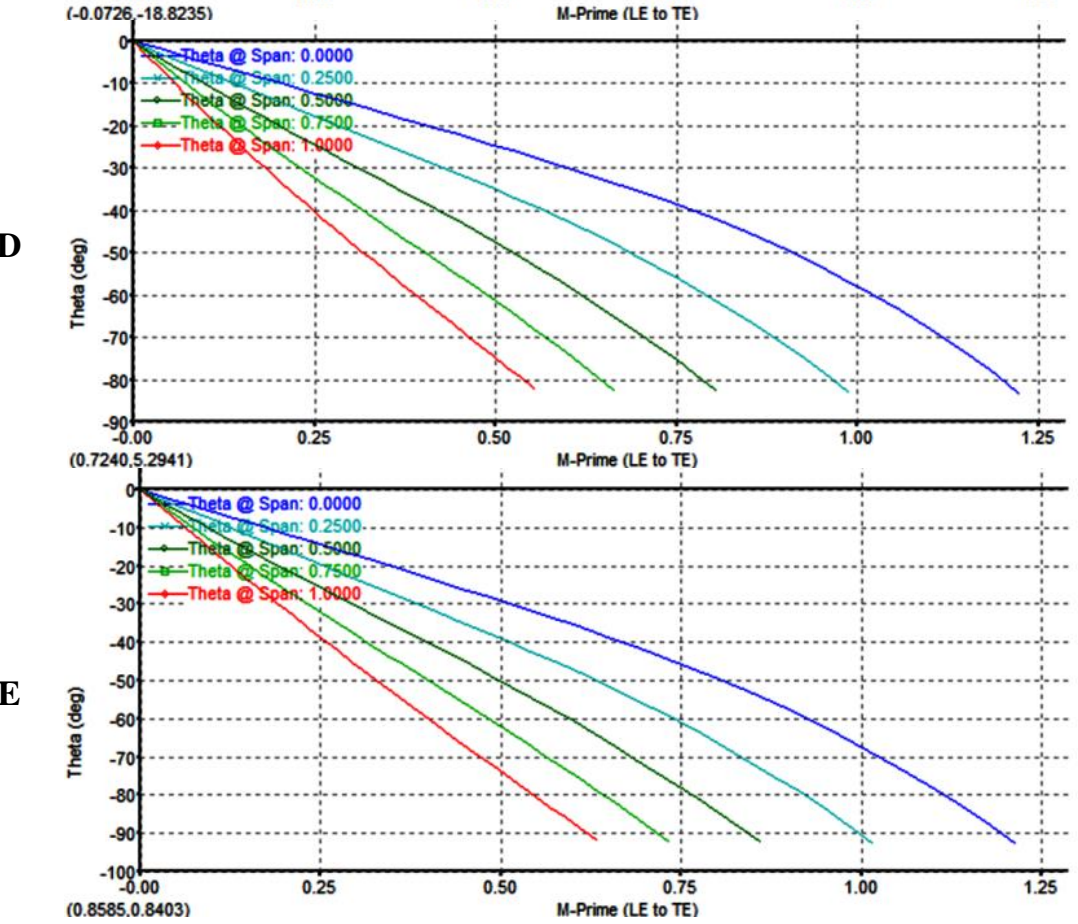

Figure 32 - The theta graph vs. M-prime position: A) $H=5 \mathrm{~m}, \mathrm{~B}) H=10 \mathrm{~m}, \mathrm{C}) H=15 \mathrm{~m}, \mathrm{D}) H=20 \mathrm{~m}$, E) $H=25 \mathrm{~m}$. 


\begin{tabular}{|c|c|c|c|c|c|c|}
\hline \multirow{4}{*}{ Impact Factor: } & ISRA (India) & $=3.117$ & SIS (USA) & $=0.912$ & ICV (Poland) & $=6.630$ \\
\hline & ISI (Dubai, UAE & $=0.829$ & РИНЦ (Russia) & $=0.156$ & PIF (India) & $=1.940$ \\
\hline & GIF (Australia) & $=0.564$ & ESJI (KZ) & $=5.015$ & IBI (India) & $=4.260$ \\
\hline & JIF & $=1.500$ & SJIF (Morocco) & $=5.667$ & & \\
\hline
\end{tabular}

A

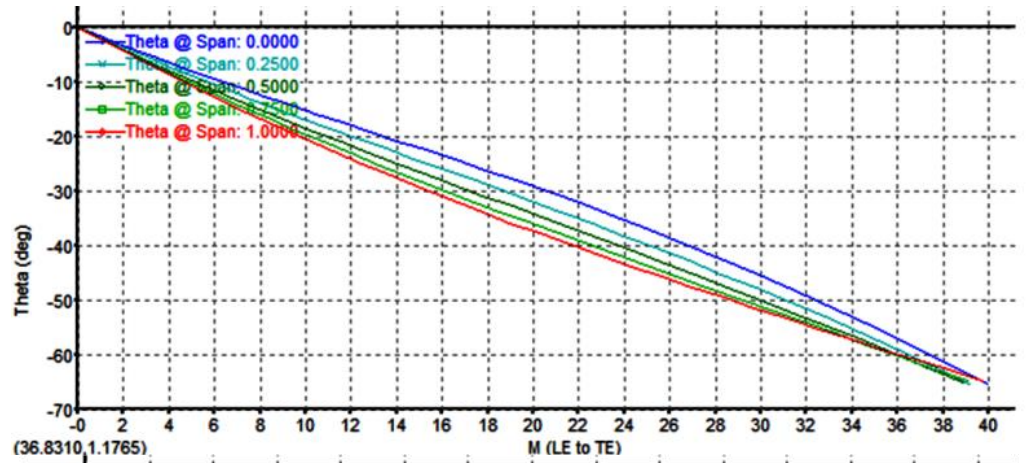

B

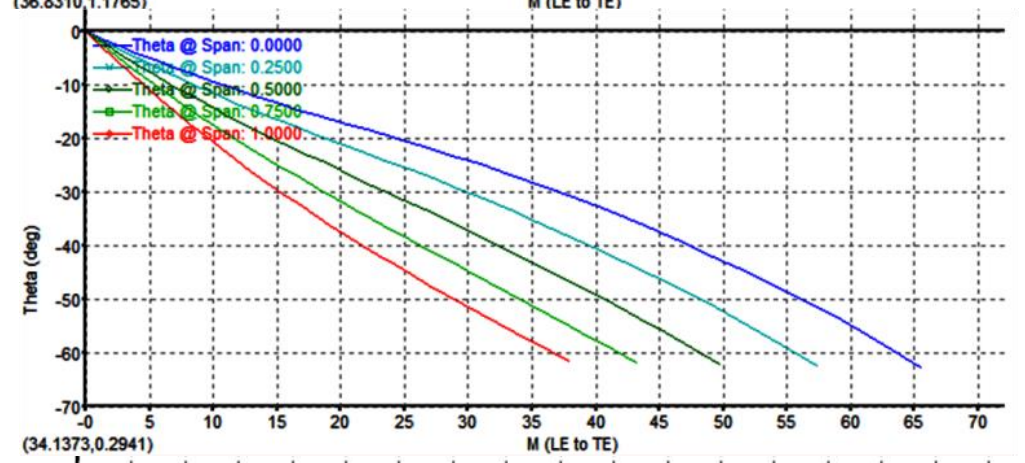

C
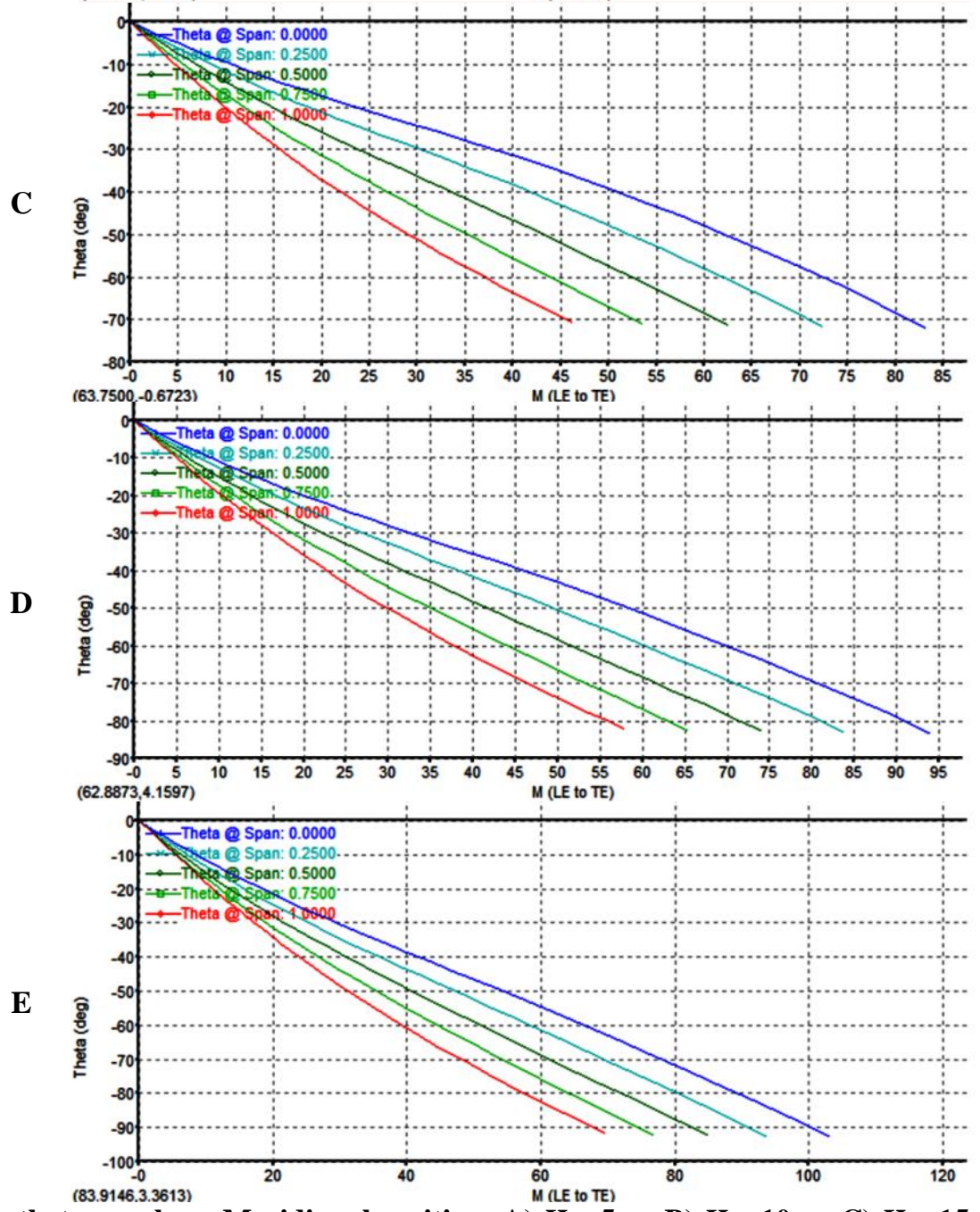

Figure 33 - The theta graph vs. Meridional position: A) $H=5 \mathrm{~m}, \mathrm{~B}) H=10 \mathrm{~m}, \mathrm{C}) H=15 \mathrm{~m}, \mathrm{D}) H=20 \mathrm{~m}$, E) $H=25 \mathrm{~m}$. 


\begin{tabular}{|c|c|c|c|c|c|c|}
\hline \multirow{4}{*}{ Impact Factor: } & ISRA (India) & $=3.117$ & SIS (USA) & $=0.912$ & ICV (Poland) & $=6.630$ \\
\hline & ISI (Dubai, UAE & $=0.829$ & РИНЦ (Russia) & $=0.156$ & PIF (India) & $=1.940$ \\
\hline & GIF (Australia) & $=0.564$ & ESJI (KZ) & $=\mathbf{5 . 0 1 5}$ & IBI (India) & $=4.260$ \\
\hline & JIF & $=1.500$ & SJIF (Morocco) & $=5.667$ & & \\
\hline
\end{tabular}

A
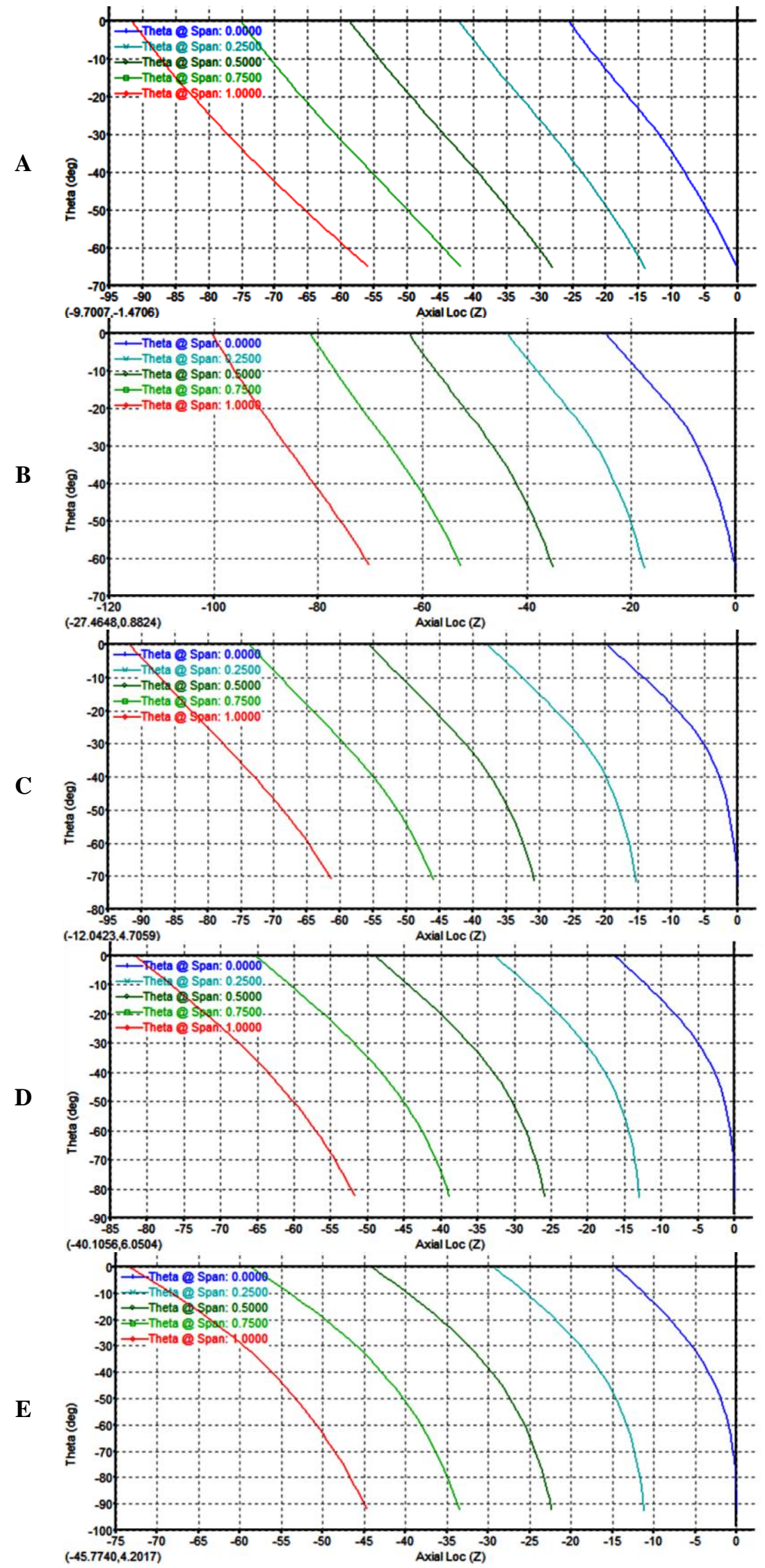

Figure 34 - The theta graph vs. Axial location (Z): A) $H=5 \mathrm{~m}, \mathrm{~B}) H=10 \mathrm{~m}, \mathrm{C}) H=15 \mathrm{~m}, \mathrm{D}) H=20 \mathrm{~m}$, E) $H=25 \mathrm{~m}$. 


\begin{tabular}{|c|c|c|c|c|c|c|}
\hline \multirow{4}{*}{ Impact Factor: } & ISRA (India) & $=3.117$ & SIS (USA) & $=0.912$ & ICV (Poland) & $=6.630$ \\
\hline & ISI (Dubai, UAE & $=\mathbf{0 . 8 2 9}$ & РИНЦ (Russia & $=0.156$ & PIF (India) & $=1.940$ \\
\hline & GIF (Australia) & $=0.564$ & ESJI (KZ) & $=5.015$ & IBI (India) & $=4.260$ \\
\hline & JIF & $=1.500$ & SJIF (Morocco & $=5.667$ & & \\
\hline
\end{tabular}

A
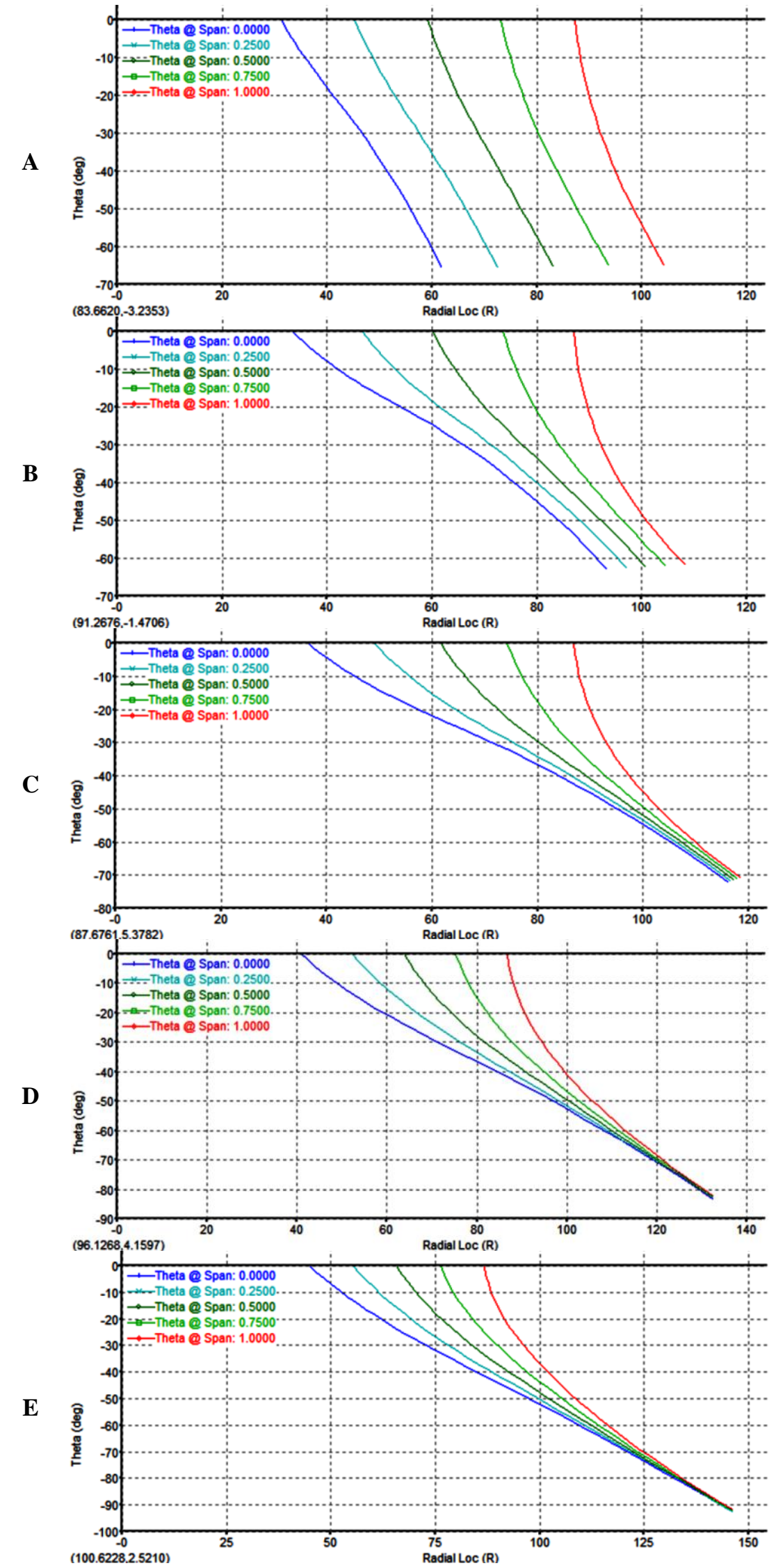

Figure 35 - The theta graph vs. Radial location $(R): A) H=5 \mathrm{~m}, \mathrm{~B}) H=10 \mathrm{~m}, \mathrm{C}) H=15 \mathrm{~m}, \mathrm{D}) H=20 \mathrm{~m}$, E) $H=25 \mathrm{~m}$. 


\begin{tabular}{|c|c|c|c|c|c|c|}
\hline \multirow{4}{*}{ Impact Factor: } & ISRA (India) & $=3.117$ & SIS (USA) & $=0.912$ & ICV (Poland) & $=6.630$ \\
\hline & ISI (Dubai, UAE & $=0.829$ & РИНЦ (Russia & $=0.156$ & PIF (India) & $=1.940$ \\
\hline & GIF (Australia) & $=0.564$ & ESJI (KZ) & $=\mathbf{5 . 0 1 5}$ & IBI (India) & $=4.260$ \\
\hline & JIF & $=1.500$ & SJIF (Morocco & $=5.667$ & & \\
\hline
\end{tabular}

A
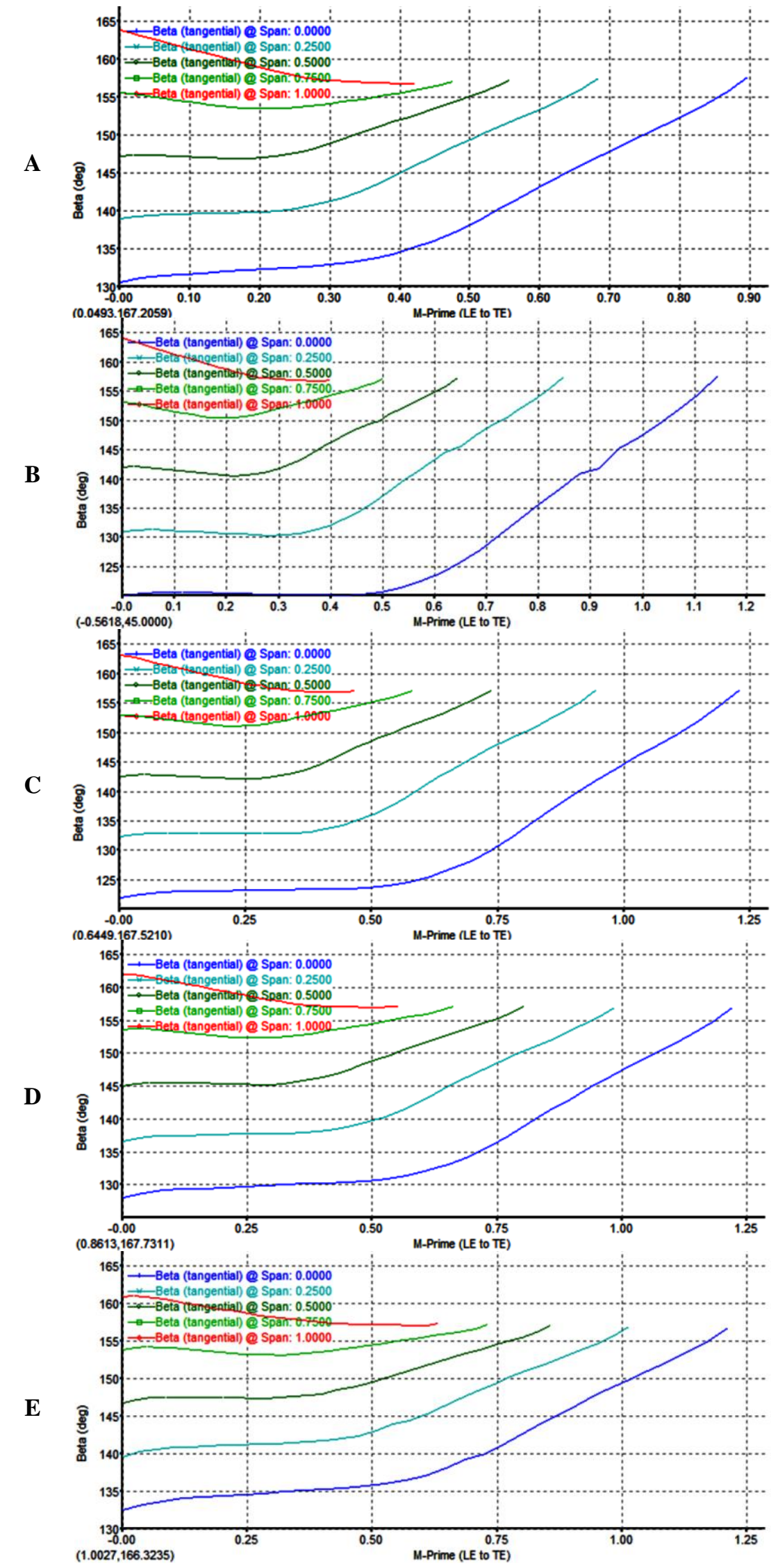

Figure 36 - The beta graph vs. M-prime position: A) $H=5 \mathrm{~m}, \mathrm{~B}) H=10 \mathrm{~m}, \mathrm{C}) H=15 \mathrm{~m}, \mathrm{D}) H=20 \mathrm{~m}$, E) $H=25 \mathrm{~m}$. 


\begin{tabular}{|c|c|c|c|c|c|c|}
\hline \multirow{4}{*}{ Impact Factor: } & ISRA (India) & $=3.117$ & SIS (USA) & $=0.912$ & ICV (Poland) & $=6.630$ \\
\hline & ISI (Dubai, UAE & $=0.829$ & РИНЦ (Russia) & $=0.156$ & PIF (India) & $=1.940$ \\
\hline & GIF (Australia) & $=0.564$ & ESJI (KZ) & $=5.015$ & IBI (India) & $=4.260$ \\
\hline & JIF & $=1.500$ & SJIF (Morocco) & $=5.667$ & & \\
\hline
\end{tabular}

A
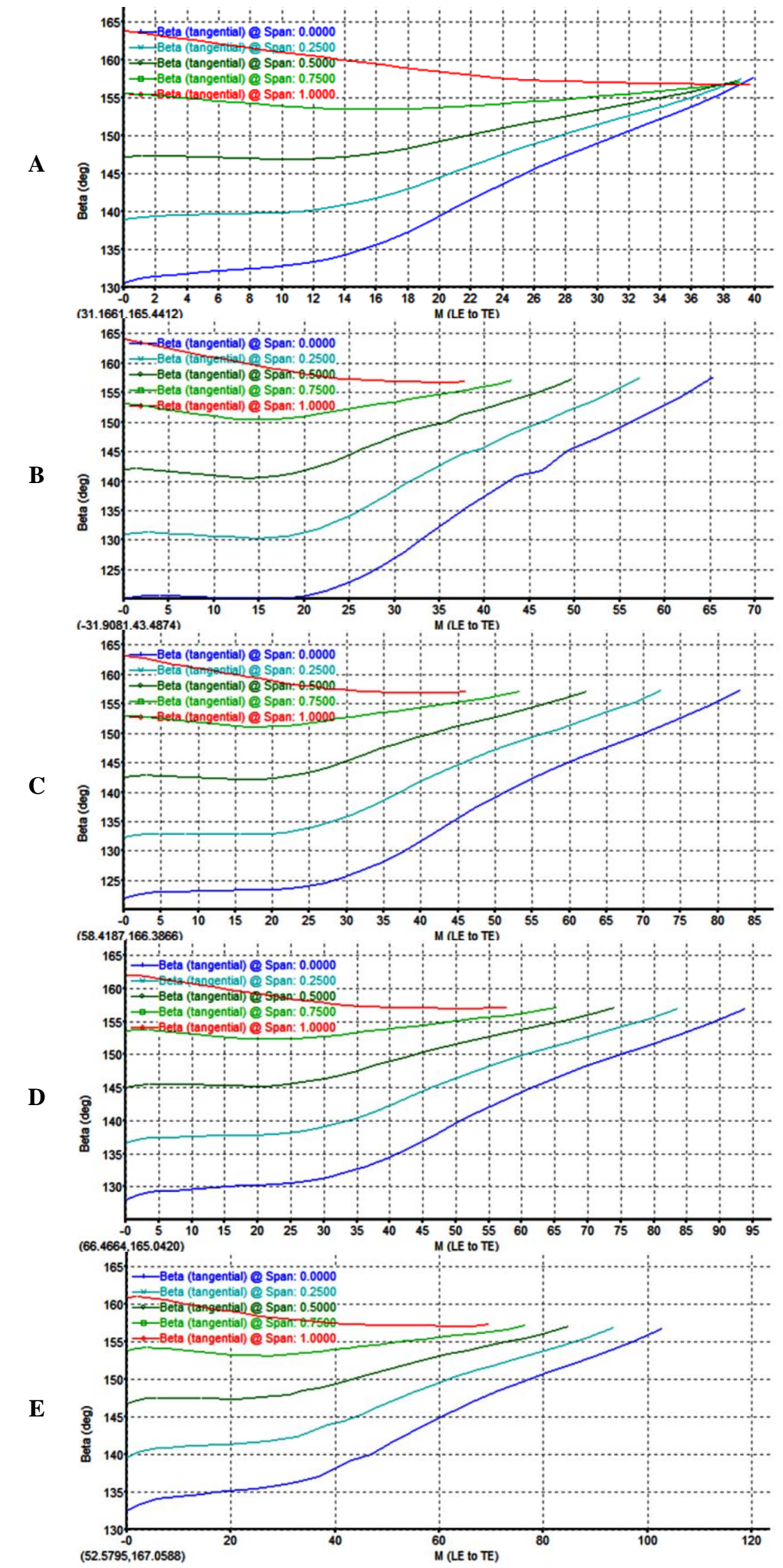

Figure 37 - The beta graph vs. Meridional position: A) $H=5 \mathrm{~m}, \mathrm{~B}) H=10 \mathrm{~m}, \mathrm{C}) H=15 \mathrm{~m}, \mathrm{D}) H=20 \mathrm{~m}$,

E) $H=25 \mathrm{~m}$. 


\begin{tabular}{|c|c|c|c|c|c|c|}
\hline \multirow{4}{*}{ Impact Factor: } & ISRA (India) & $=3.117$ & SIS (USA) & $=0.912$ & ICV (Poland) & $=6.630$ \\
\hline & ISI (Dubai, UAE & $=0.829$ & РИНЦ (Russia) & $=0.156$ & PIF (India) & $=1.940$ \\
\hline & GIF (Australia) & $=0.564$ & ESJI (KZ) & $=5.015$ & IBI (India) & $=4.260$ \\
\hline & JIF & $=1.500$ & SJIF (Morocco) & $=5.667$ & & \\
\hline
\end{tabular}

A
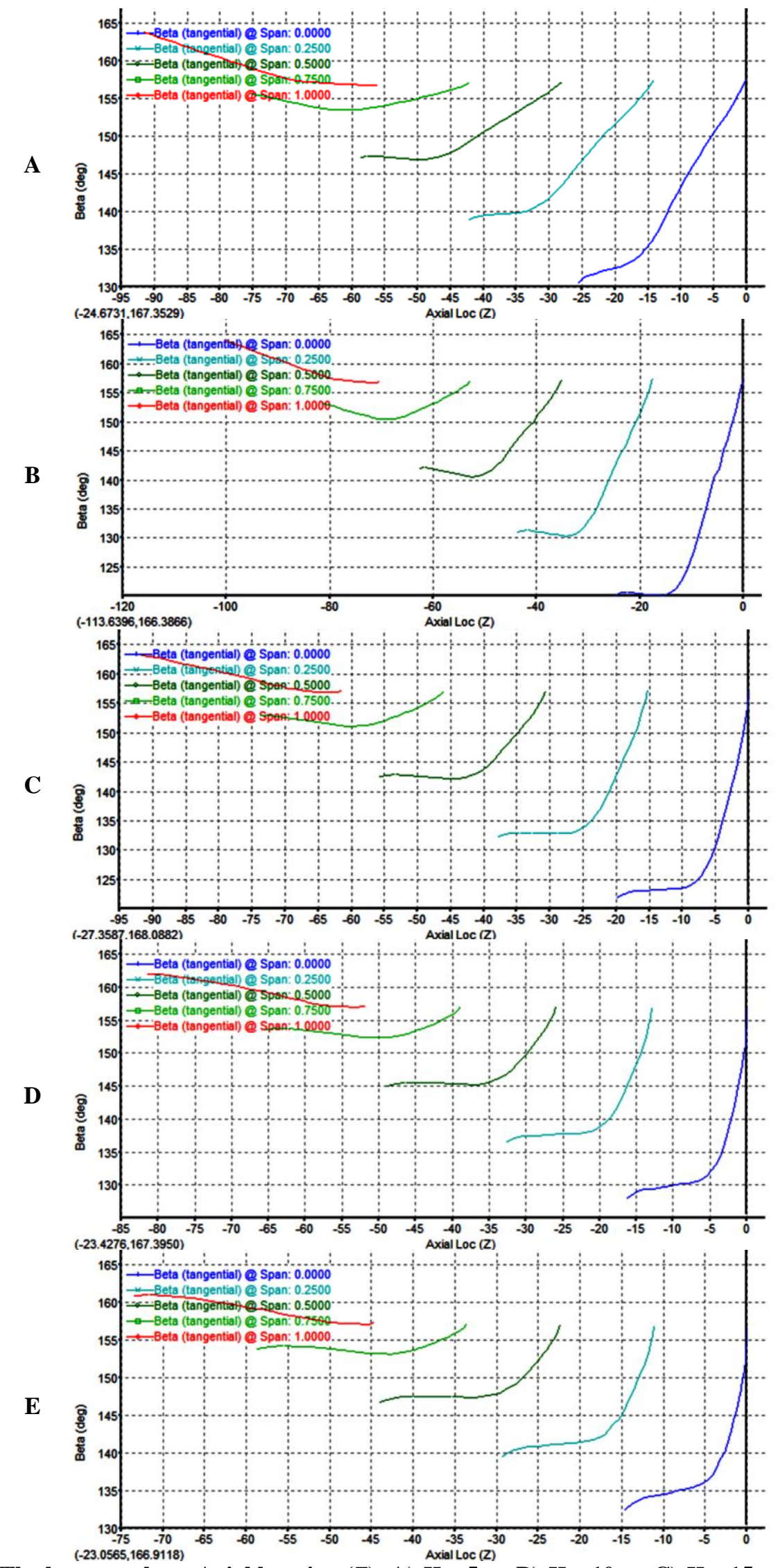

Figure 38 - The beta graph vs. Axial location (Z): A) $H=5 \mathrm{~m}, \mathrm{~B}) H=10 \mathrm{~m}, \mathrm{C}) H=15 \mathrm{~m}, \mathrm{D}) H=20 \mathrm{~m}$, E) $H=25 \mathrm{~m}$. 


\begin{tabular}{|c|c|c|c|c|c|c|}
\hline \multirow{4}{*}{ Impact Factor: } & ISRA (India) & $=3.117$ & SIS (USA) & $=0.912$ & ICV (Poland) & $=6.630$ \\
\hline & ISI (Dubai, UAE & $=0.829$ & РИНЦ (Russia) & $=0.156$ & PIF (India) & $=1.940$ \\
\hline & GIF (Australia) & $=0.564$ & ESJI (KZ) & $=5.015$ & IBI (India) & $=4.260$ \\
\hline & JIF & $=1.500$ & SJIF (Morocco) & $=5.667$ & & \\
\hline
\end{tabular}

$\mathbf{A}$
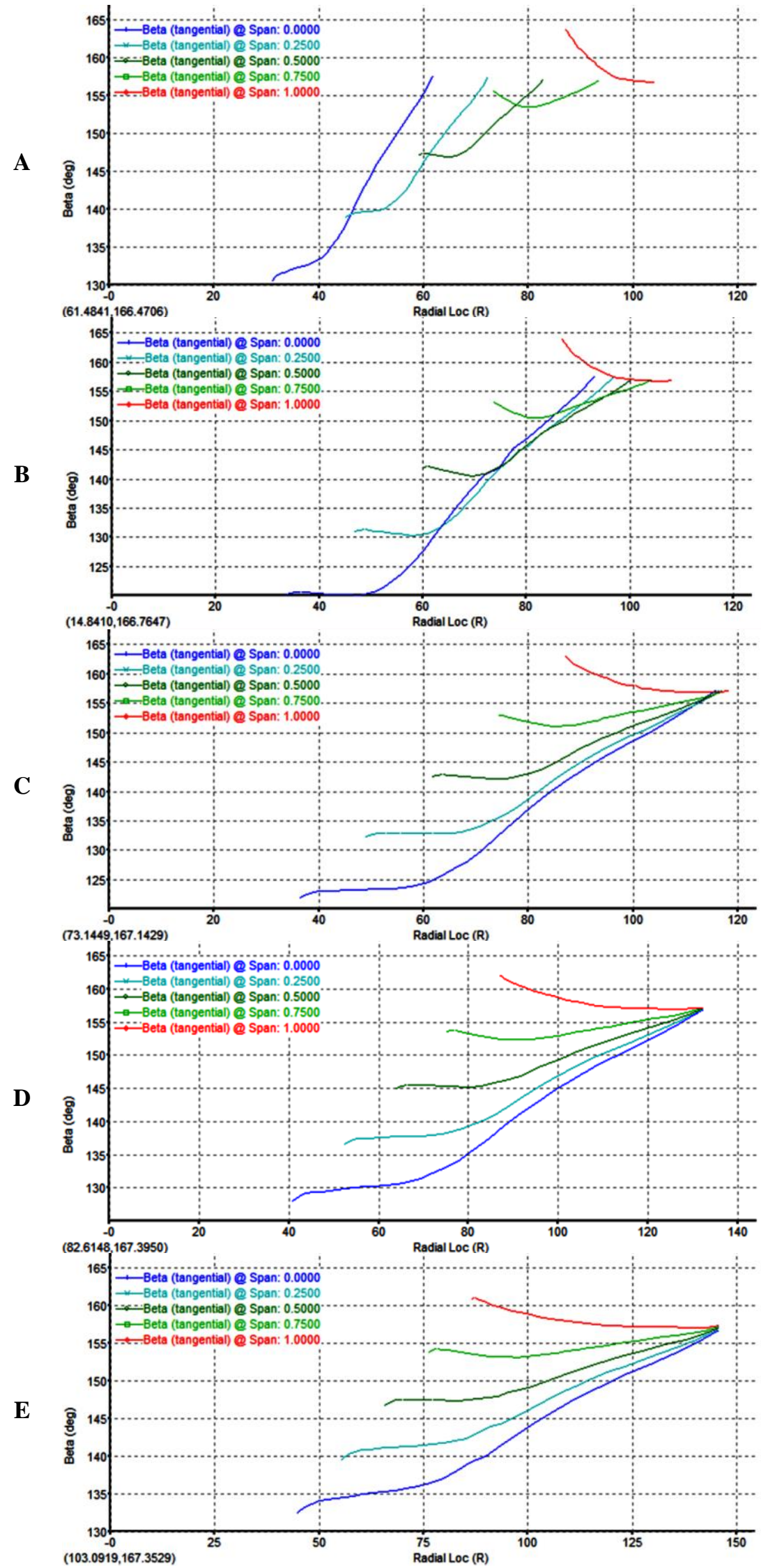

Figure 39 - The beta graph vs. Radial location $(R)$ : A) $H=5 \mathrm{~m}, \mathrm{~B}) H=10 \mathrm{~m}, \mathrm{C}) H=15 \mathrm{~m}, \mathrm{D}) H=20 \mathrm{~m}$, E) $H=25 \mathrm{~m}$. 


\begin{tabular}{|c|c|c|c|c|c|c|}
\hline \multirow{4}{*}{ Impact Factor: } & ISRA (India) & $=3.117$ & SIS (USA) & $=0.912$ & ICV (Poland) & $=6.630$ \\
\hline & ISI (Dubai, UAE & $=0.829$ & РИНЦ (Russia) & $=0.156$ & PIF (India) & $=1.940$ \\
\hline & GIF (Australia) & $=0.564$ & ESJI (KZ) & $=5.015$ & IBI (India) & $=4.260$ \\
\hline & JIF & $=1.500$ & SJIF (Morocco) & $=5.667$ & & \\
\hline
\end{tabular}

A
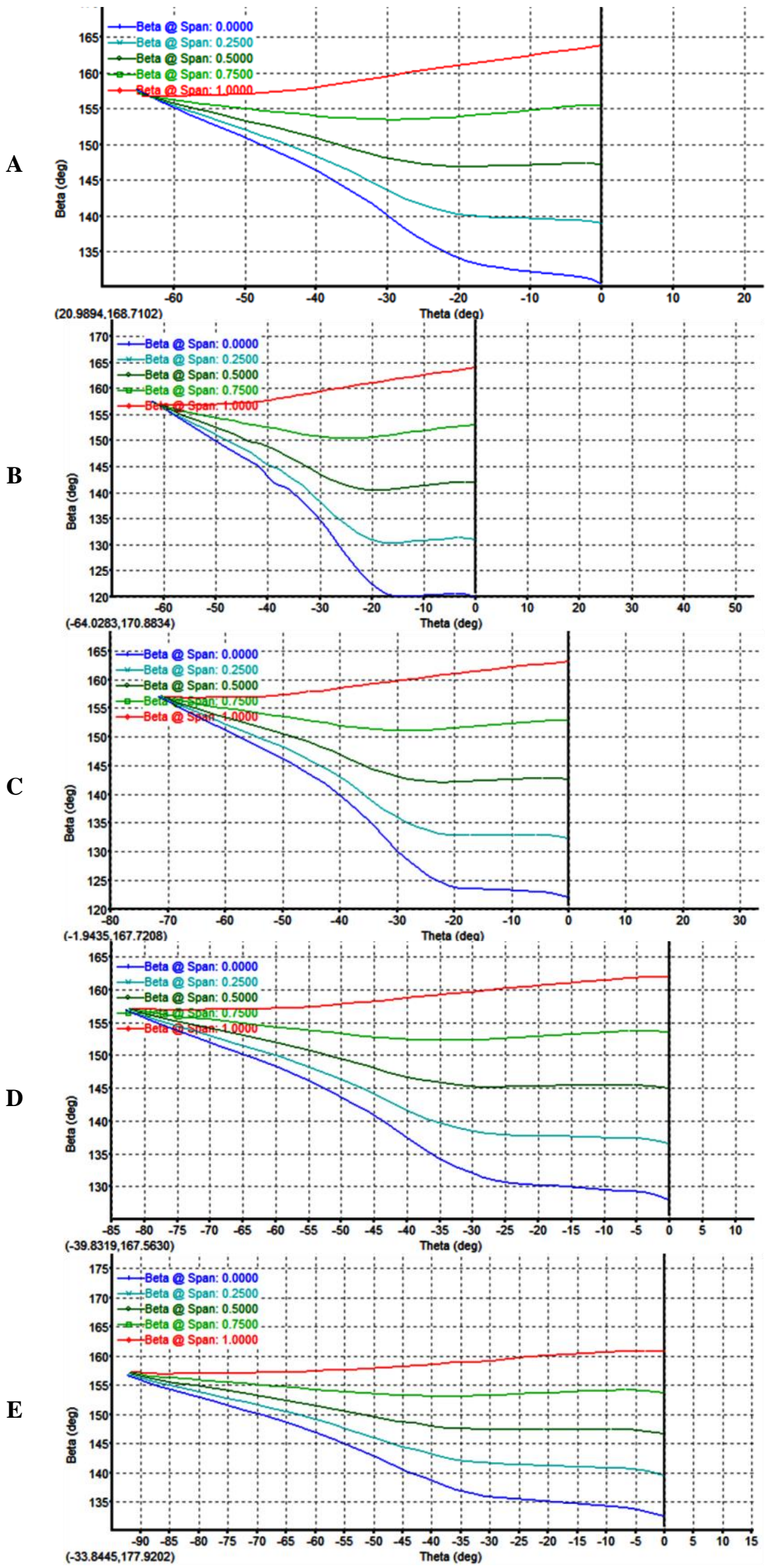

Figure 40 - The beta vs. theta graph: A) $H=5 \mathrm{~m}, \mathrm{~B}) H=10 \mathrm{~m}, \mathrm{C}) H=15 \mathrm{~m}, \mathrm{D}) H=20 \mathrm{~m}, \mathrm{E}) H=25 \mathrm{~m}$. 


\begin{tabular}{llrllll} 
& ISRA (India) & $=\mathbf{3 . 1 1 7}$ & SIS (USA) & $=\mathbf{0 . 9 1 2}$ & ICV (Poland) & $\mathbf{= 6 . 6 3 0}$ \\
Impact Factor: & ISI (Dubai, UAE) $=\mathbf{0 . 8 2 9}$ & PUHЦ (Russia) $=\mathbf{0 . 1 5 6}$ & PIF (India) & $=\mathbf{1 . 9 4 0}$ \\
& GIF (Australia) & $=\mathbf{0 . 5 6 4}$ & ESJI (KZ) & $=\mathbf{5 . 0 1 5}$ & IBI (India) & $=\mathbf{4 . 2 6 0}$ \\
& JIF & $=\mathbf{1 . 5 0 0}$ & SJIF (Morocco) $=\mathbf{5 . 6 6 7}$ & & \\
\hline
\end{tabular}

A
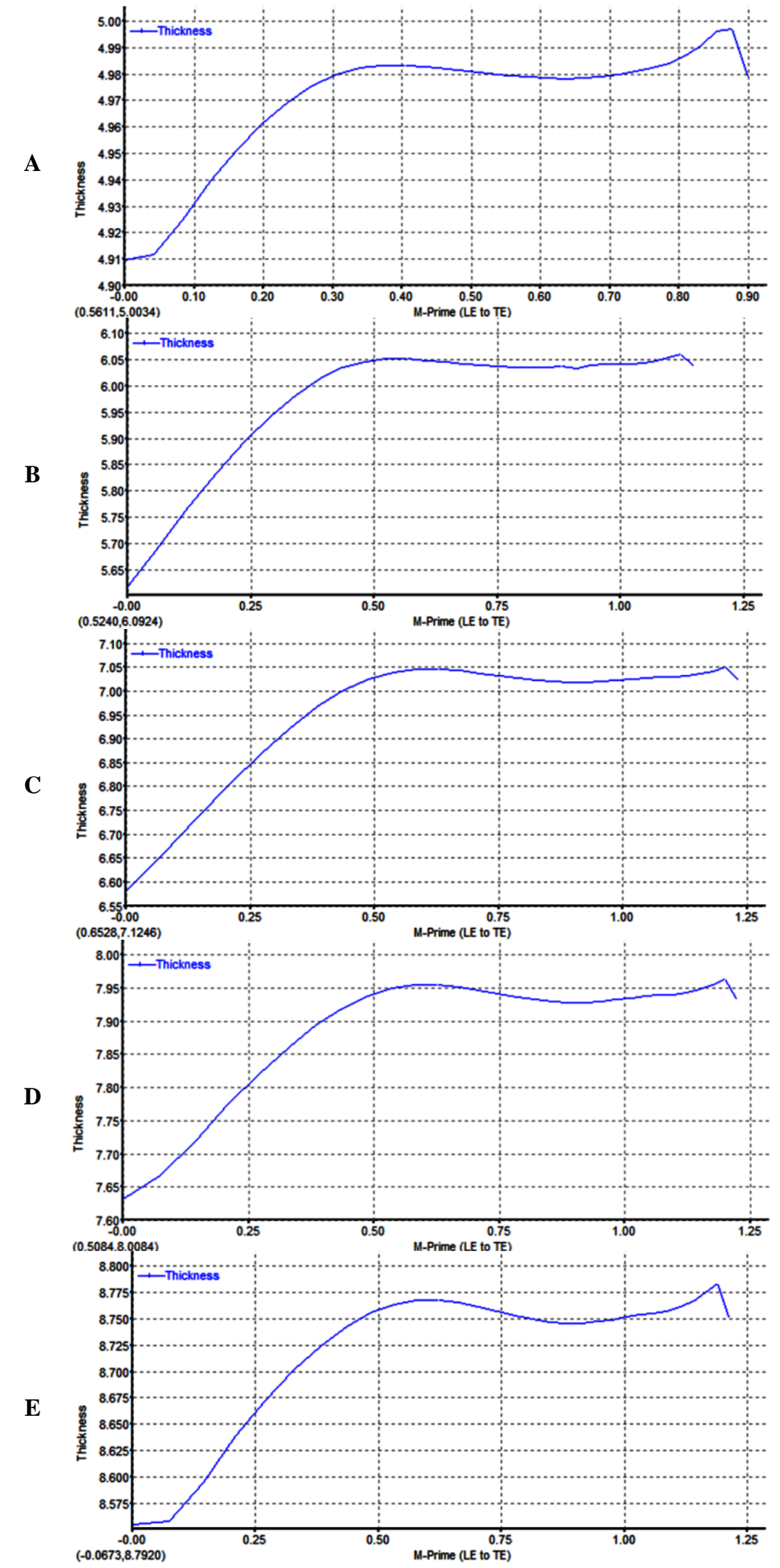

Figure 41 - The blade thickness graph vs. M-prime position: A) $H=5 \mathrm{~m}, \mathrm{~B}) H=10 \mathrm{~m}, \mathrm{C}) H=15 \mathrm{~m}$, D) $H=20 \mathrm{~m}$, E) $H=25 \mathrm{~m}$. 


\begin{tabular}{|c|c|c|c|c|c|c|}
\hline \multirow{4}{*}{ Impact Factor: } & ISRA (India) & $=3.117$ & SIS (USA) & $=0.912$ & ICV (Poland) & $=6.630$ \\
\hline & ISI (Dubai, UAE & $=0.829$ & РИНЦ (Russia) & $=0.156$ & PIF (India) & $=1.940$ \\
\hline & GIF (Australia) & $=0.564$ & ESJI (KZ) & $=\mathbf{5 . 0 1 5}$ & IBI (India) & $=4.260$ \\
\hline & JIF & $=1.500$ & SJIF (Morocco) & $=5.667$ & & \\
\hline
\end{tabular}

A
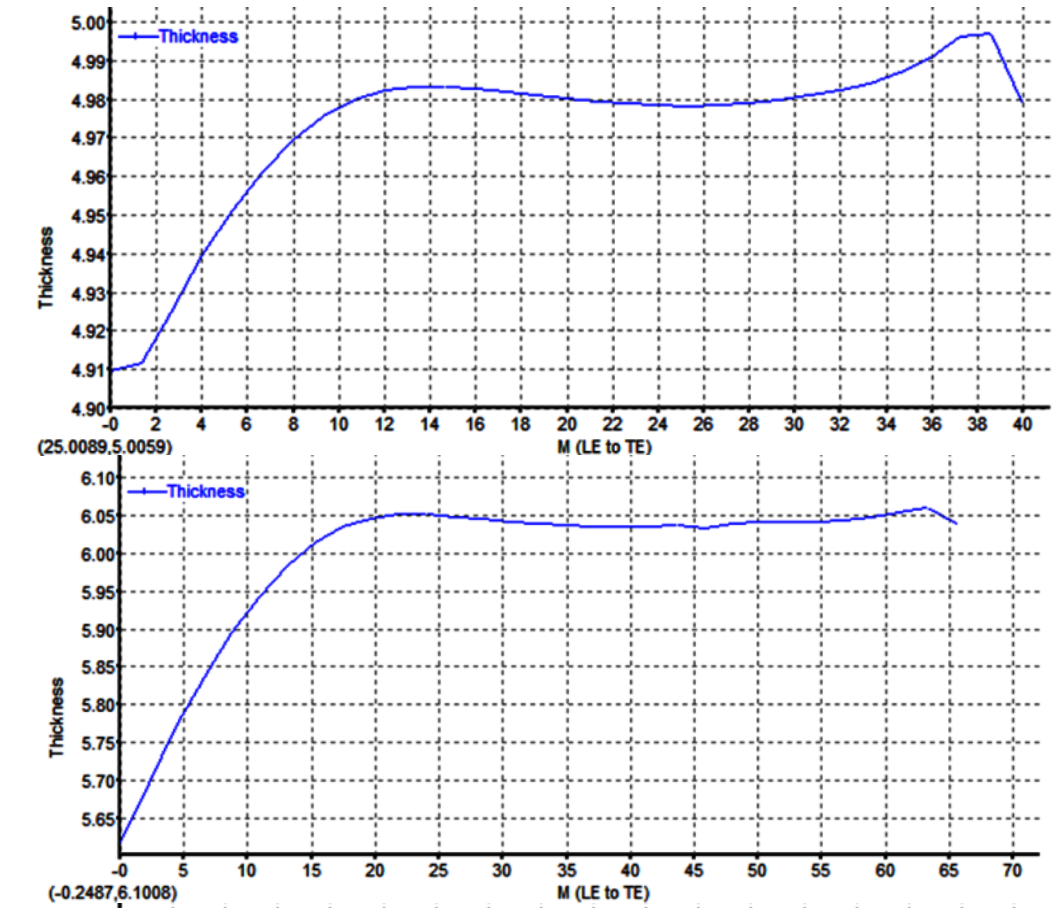

B
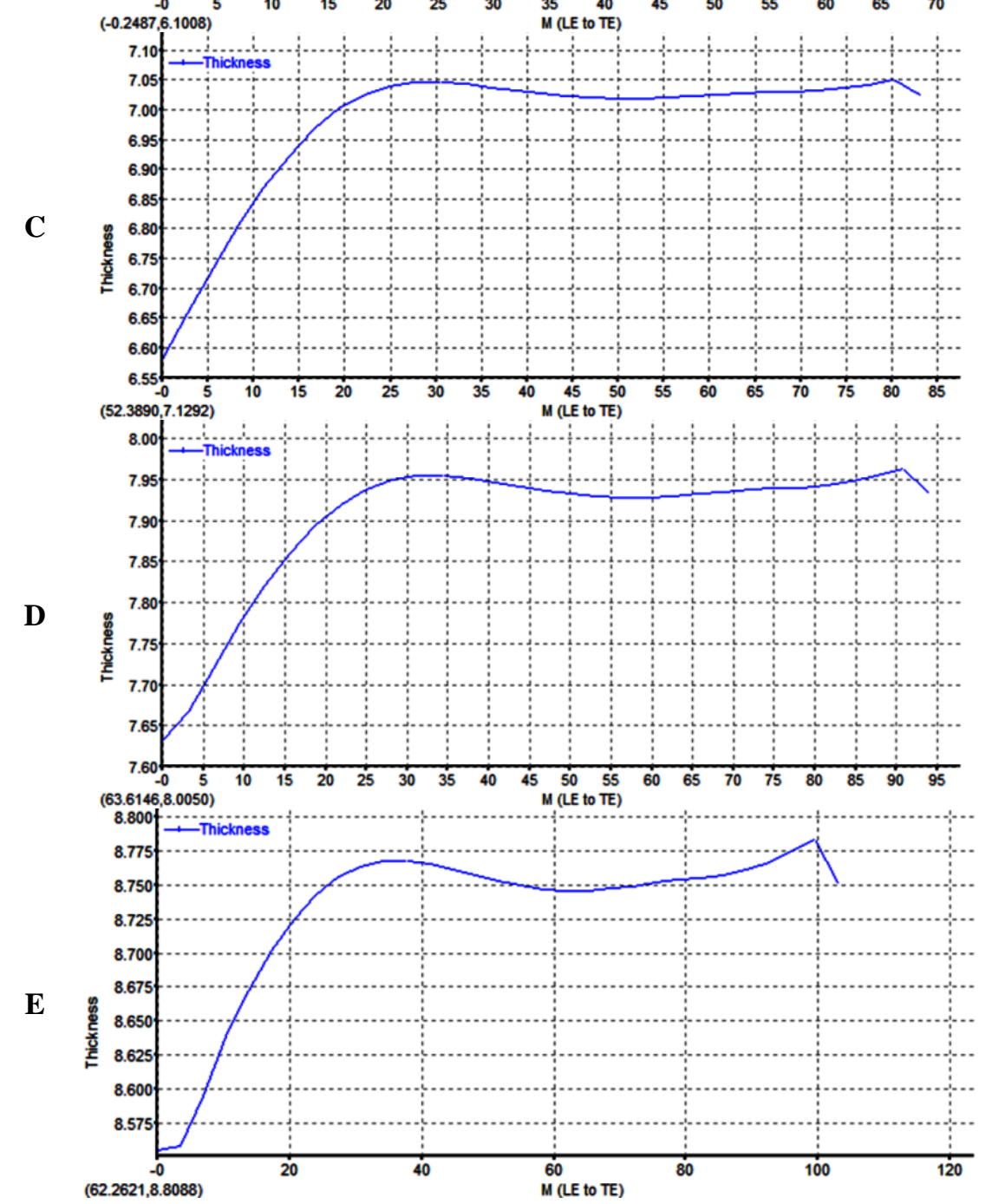

Figure 42 - The blade thickness graph vs. Meridional position: A) $H=5 \mathrm{~m}, \mathrm{~B}) H=10 \mathrm{~m}, \mathrm{C}) H=15 \mathrm{~m}$, D) $H=20 \mathrm{~m}$, E) $H=25 \mathrm{~m}$. 


\begin{tabular}{llllll} 
& ISRA (India) $=\mathbf{3 . 1 1 7}$ & SIS (USA) & $=\mathbf{0 . 9 1 2}$ & ICV (Poland) & $=\mathbf{6 . 6 3 0}$ \\
Impact Factor: & ISI (Dubai, UAE) $=\mathbf{0 . 8 2 9}$ & PUIHL (Russia) $=\mathbf{0 . 1 5 6}$ & PIF (India) & $=\mathbf{1 . 9 4 0}$ \\
GIF (Australia) & $=\mathbf{0 . 5 6 4}$ & ESJI (KZ) & $\mathbf{5 . 0 1 5}$ & IBI (India) & $\mathbf{4 . 2 6 0}$ \\
& JIF & $\mathbf{1 . 5 0 0}$ & SJIF (Morocco) $=\mathbf{5 . 6 6 7}$ & & \\
\hline
\end{tabular}

A
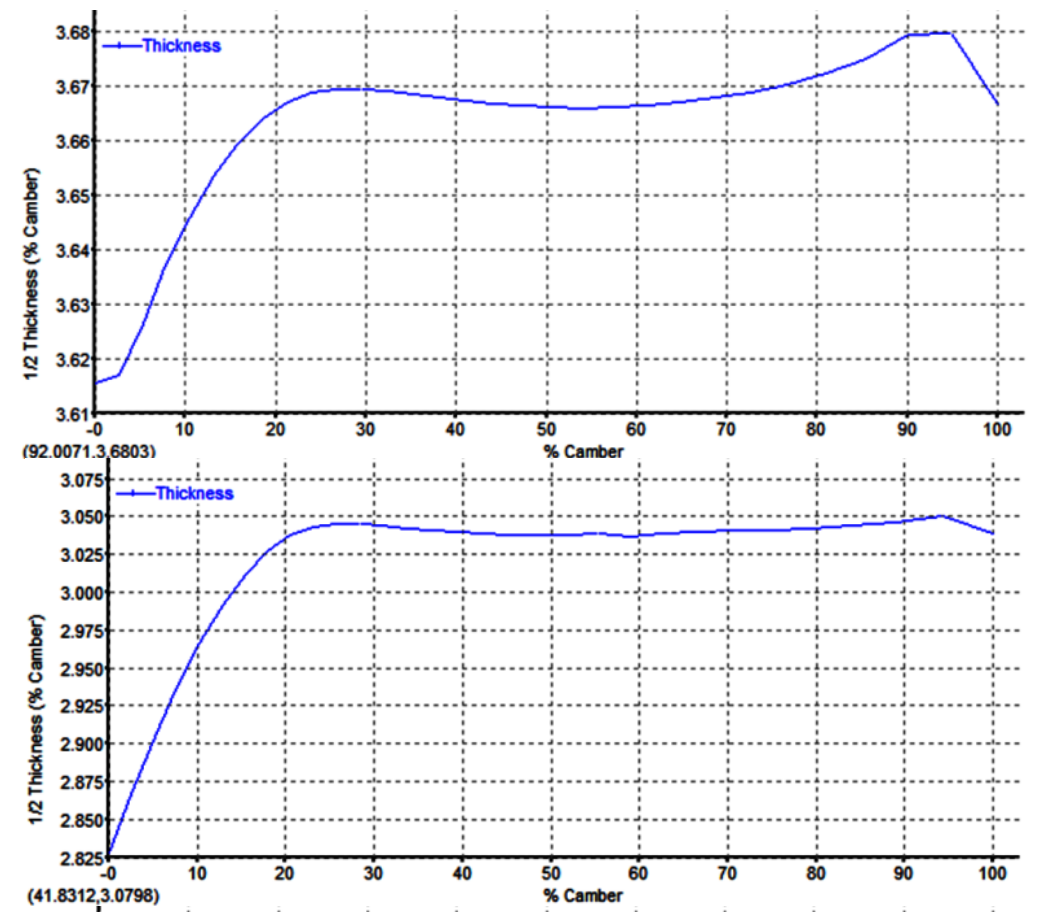

B
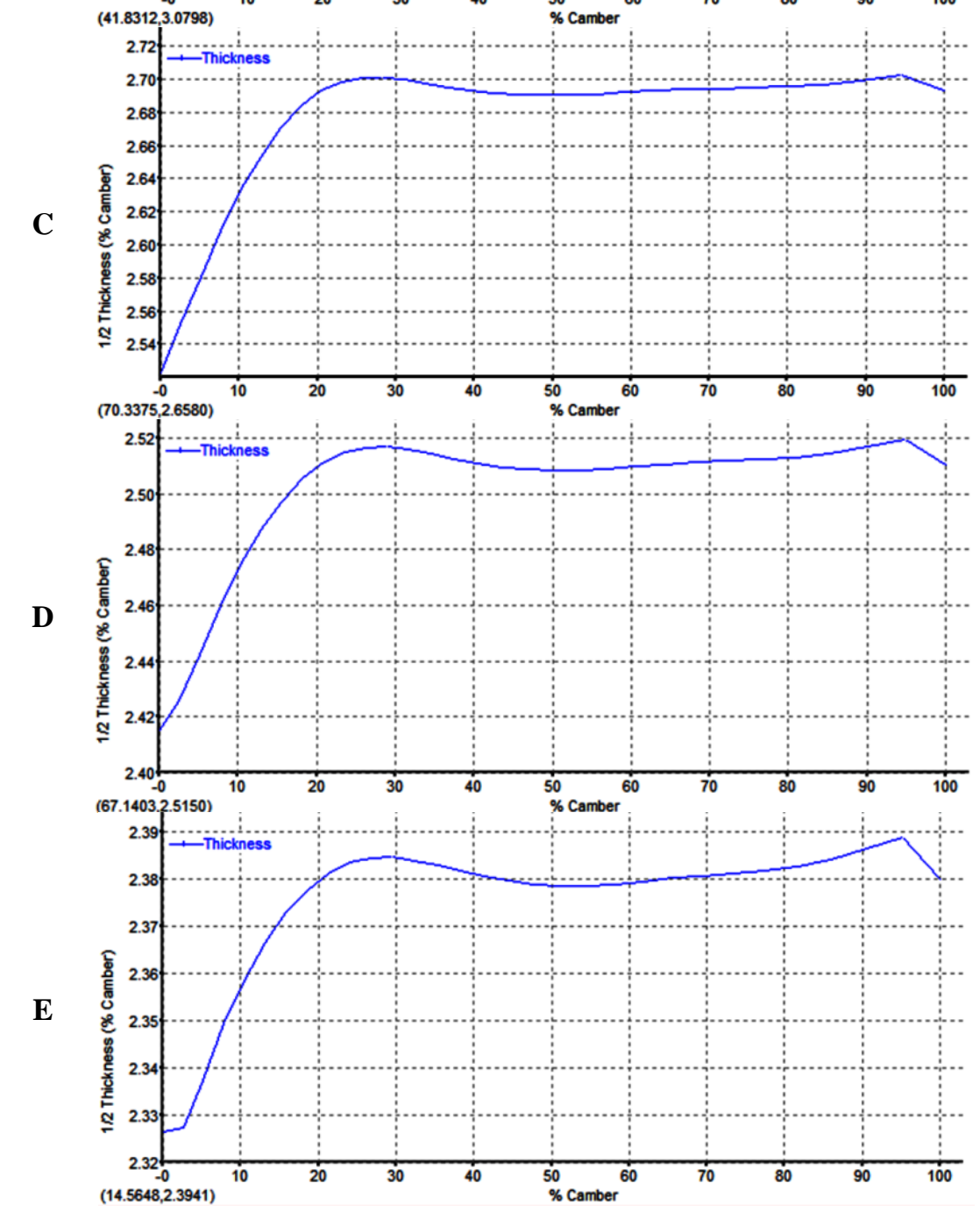

Figure 43 - The blade thickness graph - \% camber vs. \% camber length: A) $H=5 \mathrm{~m}, \mathrm{~B}) H=10 \mathrm{~m}$, C) $H=15 \mathrm{~m}, \mathrm{D}) H=20 \mathrm{~m}, \mathrm{E}) H=25 \mathrm{~m}$. 


\begin{tabular}{|c|c|c|c|c|c|c|}
\hline \multirow{4}{*}{ Impact Factor: } & ISRA (India) & $=3.117$ & SIS (USA) & $=0.912$ & ICV (Poland) & $=6.630$ \\
\hline & ISI (Dubai, UAE & $=0.829$ & РИНЦ (Russia & $=0.156$ & PIF (India) & $=1.940$ \\
\hline & GIF (Australia) & $=0.564$ & ESJI (KZ) & $=5.015$ & IBI (India) & $=4.260$ \\
\hline & JIF & $=1.500$ & SJIF (Morocco & $=5.667$ & & \\
\hline
\end{tabular}

A
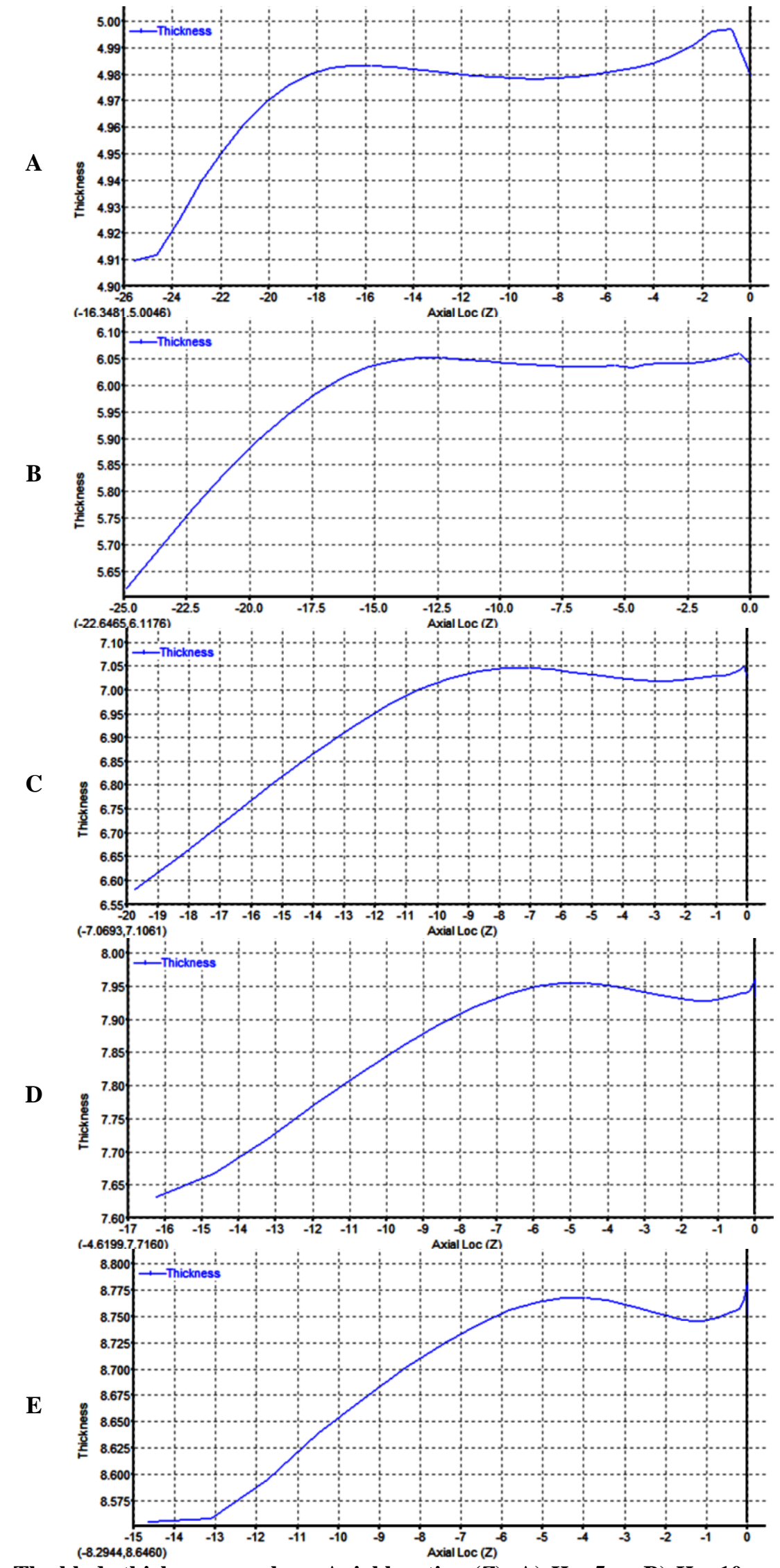

Figure 44 - The blade thickness graph vs. Axial location (Z): A) $H=5 \mathrm{~m}, \mathrm{~B}) H=10 \mathrm{~m}, \mathrm{C}) H=15 \mathrm{~m}$, D) $H=20 \mathrm{~m}$, E) $H=25 \mathrm{~m}$. 


\begin{tabular}{|c|c|c|c|c|c|c|}
\hline \multirow{4}{*}{ Impact Factor: } & ISRA (India) & $=3.117$ & SIS (USA) & $=0.912$ & ICV (Poland) & $=6.630$ \\
\hline & ISI (Dubai, UAE & $=0.829$ & РИНЦ (Russia) & $=0.156$ & PIF (India) & $=1.940$ \\
\hline & GIF (Australia) & $=0.564$ & ESJI (KZ) & $=5.015$ & IBI (India) & $=4.260$ \\
\hline & JIF & $=1.500$ & SJIF (Morocco) & $=5.667$ & & \\
\hline
\end{tabular}

A
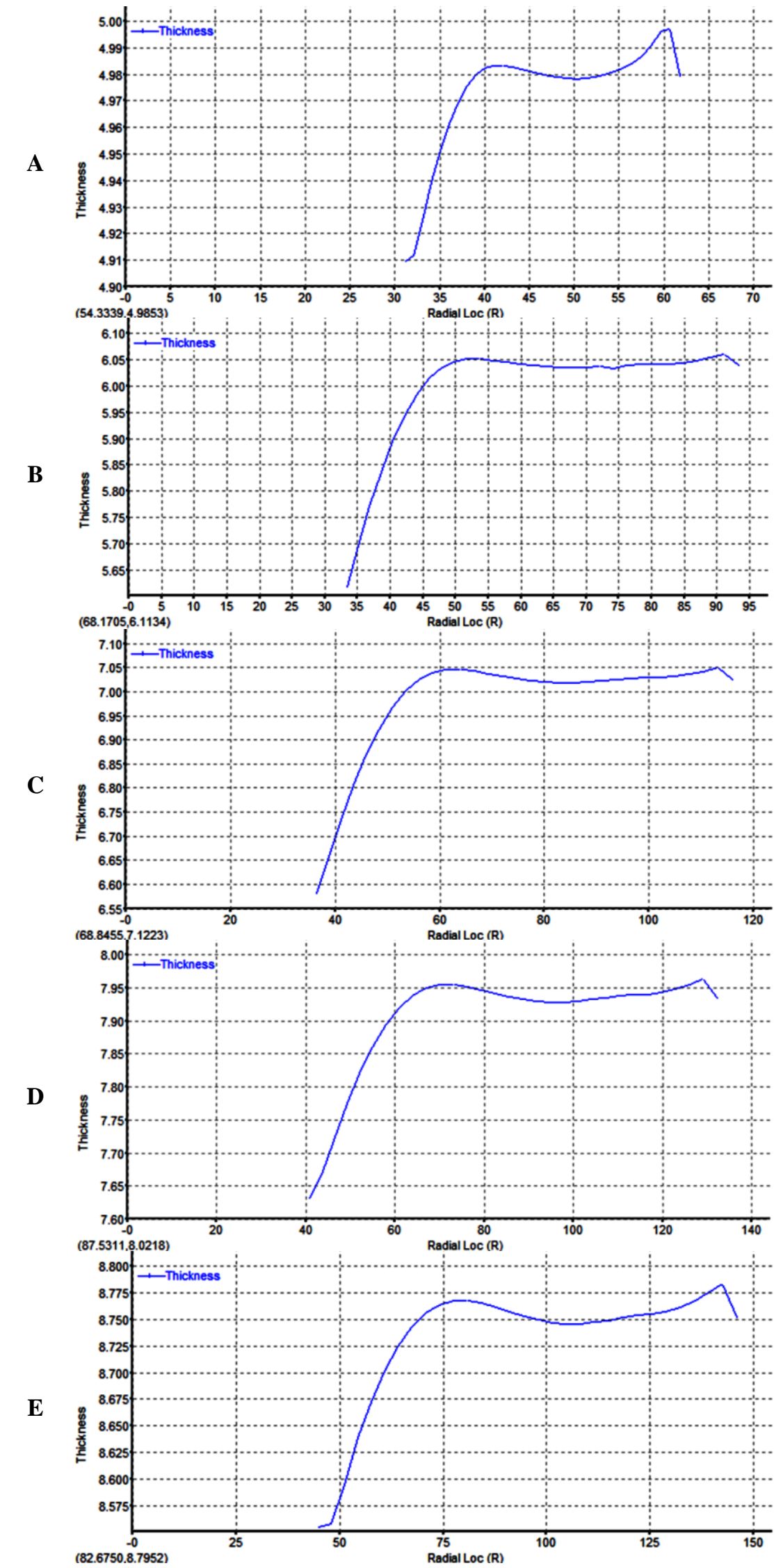

Figure 45 - The blade thickness graph vs. Radial location $(R)$ : A) $H=5 \mathrm{~m}, \mathrm{~B}) H=10 \mathrm{~m}, \mathrm{C}) H=15 \mathrm{~m}$, D) $H=20 \mathrm{~m}, \mathrm{E}) H=25 \mathrm{~m}$. 


\begin{tabular}{|c|c|c|c|c|c|c|}
\hline \multirow{4}{*}{ Impact Factor: } & ISRA (India) & $=3.117$ & SIS (USA) & $=0.912$ & ICV (Poland) & $=6.630$ \\
\hline & ISI (Dubai, UAE & $=0.829$ & РИНЦ (Russia) & $=0.156$ & PIF (India) & $=1.940$ \\
\hline & GIF (Australia) & $=0.564$ & ESJI (KZ) & $=5.015$ & IBI (India) & $=4.260$ \\
\hline & JIF & $=1.500$ & SJIF (Morocco) & $=5.667$ & & \\
\hline
\end{tabular}

The dependencies of the impellers blades thickness from $M$-Prime, $M$, \% camber length (the current thickness graph with the vertical axis displaying the blade thickness as the percent of the total camber length and the horizontal axis displaying location as the percent of the total camber length), $Z$ and $R$ are calculated in the Fig. $41-45$. These graphs are an addition to the color contours of normal thickness of the impellers blades.

$\mathbf{A}$

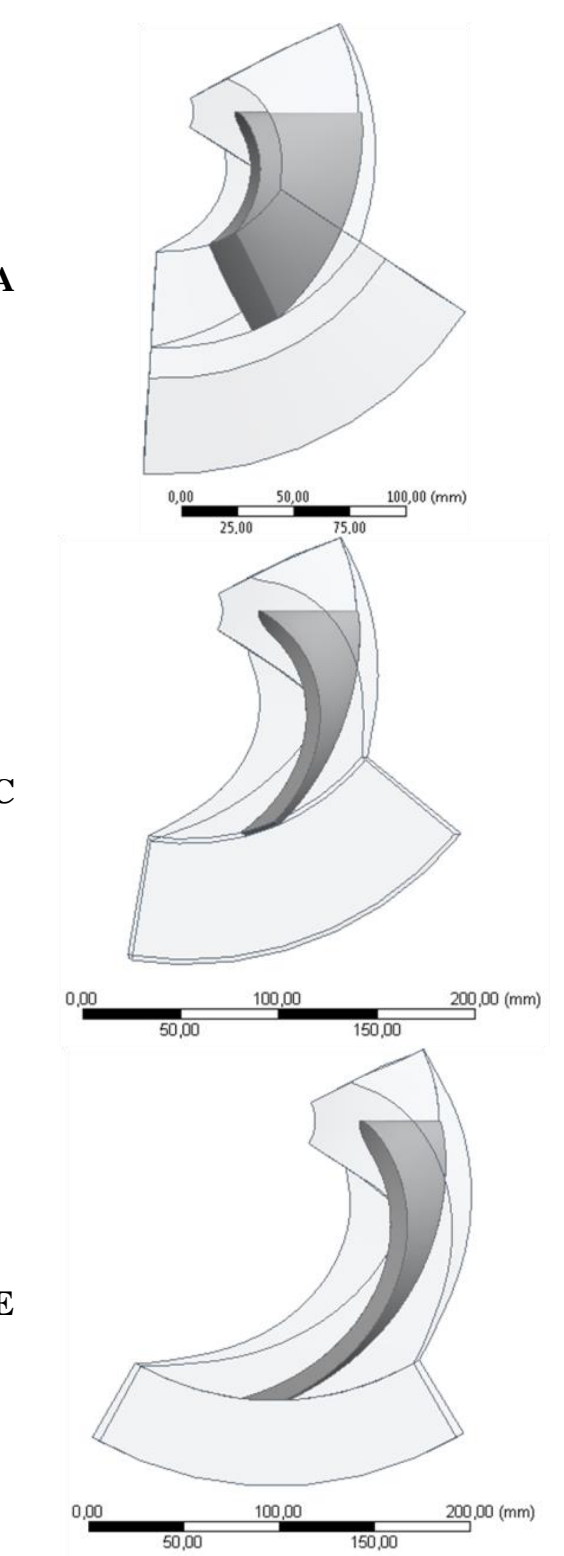

C
The three-dimensional models of the impellers blades at the different pump heads (the Fig. 46) were built in the Model module of the Ansys Workbench software environment. The transparent volume is the created area for the calculation. The dimensions of the leading edge of the blade are presented in a foreground of the created area; the dimensions of the trailing edge of the blade are presented in a background of the created area.

B

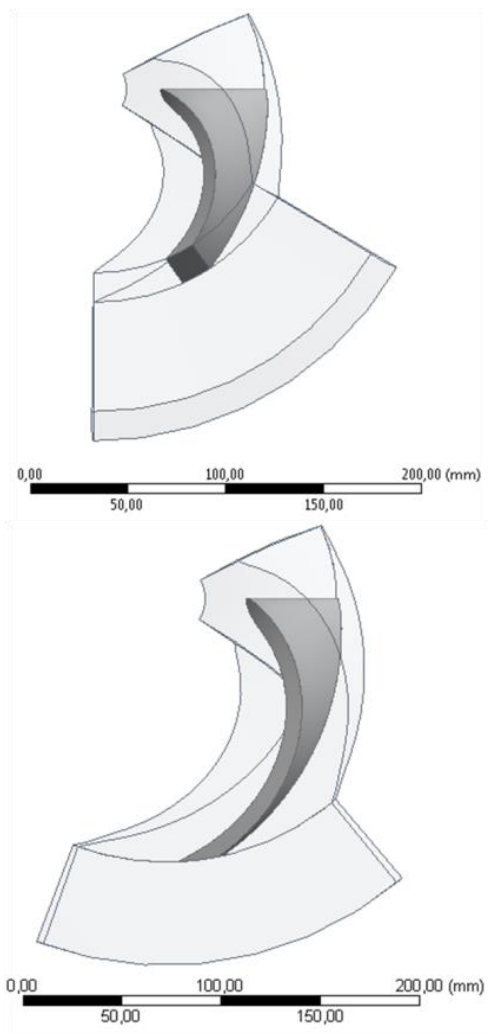

Figure 46 - The three-dimensional model of the impeller blade: A) $H=5 \mathrm{~m}, \mathrm{~B}) H=10 \mathrm{~m}, \mathrm{C}) H=15 \mathrm{~m}$, D) $H=20 \mathrm{~m}, \mathrm{E}) H=25 \mathrm{~m}$.

\section{Results and discussion}

The calculated values of the operating and geometric parameters of the impellers at the different pump heads values are presented in the summary table 3 .

The parameters of specific speed determine a geometric shape of the pump. $\Omega s$ is the non- dimensional coefficient of specific speed. A type of the pump impeller is determined by the value of this coefficient. It is necessary to choose the mixed flow impeller at the pump head is $5-15 \mathrm{~m}$. The radial impeller is selected at the pump head more than 20 $\mathrm{m}$. Ns and $n q$ are equivalent forms of $\Omega s$. These 


\begin{tabular}{|c|c|c|c|c|c|c|}
\hline \multirow{4}{*}{ Impact Factor: } & ISRA (India) & $=3.117$ & SIS (USA) & $=0.912$ & ICV (Poland) & $=6.630$ \\
\hline & ISI (Dubai, UAE & $=0.829$ & РИНЦ (Russia) & $=0.156$ & PIF (India) & $=1.940$ \\
\hline & GIF (Australia) & $=0.564$ & ESJI (KZ) & $=\mathbf{5 . 0 1 5}$ & IBI (India) & $=4.260$ \\
\hline & JIF & $=1.500$ & SJIF (Morocco) & $=5.667$ & & \\
\hline
\end{tabular}

parameters are used for the calculation of specific

speed of the pump in Europe and the USA.

Table 3. The calculated operating and geometrical parameters of the impellers/pump.

\begin{tabular}{|c|c|c|c|c|c|c|c|c|c|c|c|}
\hline \multicolumn{12}{|c|}{ Overall performance } \\
\hline \multirow{2}{*}{$\begin{array}{c}\text { Pump } \\
\text { head, } \\
m\end{array}$} & \multicolumn{11}{|c|}{ Parameter } \\
\hline & $\Omega s$ & $N s$ & $n q$ & Nss & $\begin{array}{c}\text { Power, } \\
k W\end{array}$ & $\begin{array}{l}\text { Head } \\
\text { coeff }\end{array}$ & Flow coeff & Ks & \multicolumn{2}{|c|}{$N P S H r, m$} & $\begin{array}{l}\text { Diffn } \\
\text { ratio }\end{array}$ \\
\hline 5 & 2.48 & 6789 & 131.5 & 3.15 & 5.6 & 0.289 & 0.239 & 0.87 & \multicolumn{2}{|c|}{3.64} & 0.088 \\
\hline 10 & 1.48 & 4037 & 78.2 & 3.15 & 10.5 & 0.392 & 0.134 & 0.897 & \multicolumn{2}{|c|}{3.64} & 0.121 \\
\hline 15 & 1.09 & 2978 & 57.7 & 3.15 & 15.7 & 0.435 & 0.085 & 0.953 & \multicolumn{2}{|c|}{3.64} & 0.101 \\
\hline 20 & 0.88 & 2400 & 46.5 & 3.15 & 20.9 & 0.455 & 0.059 & 0.996 & \multicolumn{2}{|c|}{3.64} & 0.073 \\
\hline 25 & 0.74 & 2030 & 39.3 & 3.15 & 26.2 & 0.467 & 0.044 & 1.028 & \multicolumn{2}{|c|}{3.64} & 0.049 \\
\hline \multicolumn{12}{|c|}{ Impeller inlet } \\
\hline \multirow{2}{*}{$\begin{array}{c}\text { Pump } \\
\text { head, } \\
m\end{array}$} & \multicolumn{11}{|c|}{ Parameter } \\
\hline & $\mathrm{Dl}, \mathrm{mm}$ & $\mathrm{Cu} 1, \mathrm{~m} / \mathrm{s}$ & $\mathrm{Cm} 1, \mathrm{~m} / \mathrm{s}$ & $\begin{array}{l}U 1, \\
\mathrm{~m} / \mathrm{s}\end{array}$ & $W 1, \mathrm{~m} / \mathrm{s}$ & $\begin{array}{l}\beta^{\prime} 1, \\
\text { deg }\end{array}$ & $\beta 1$, deg & Inc, deg & $\begin{array}{l}\text { Dh, } \\
m m\end{array}$ & $\begin{array}{l}\mathrm{De}, \\
\mathrm{mm}\end{array}$ & $\begin{array}{l}\text { Thk, } \\
m m\end{array}$ \\
\hline \multirow{3}{*}{5} & 62.3 & 0 & 3.69 & 4.9 & 6.13 & 42.65 & 37.01 & 5.65 & \multirow{3}{*}{25.6} & \multirow{3}{*}{172.6} & \multirow{3}{*}{5} \\
\hline & 118.4 & 0 & 4.1 & 9.3 & 10.16 & 25.88 & 23.8 & 2.08 & & & \\
\hline & 174.4 & 0 & 4.51 & 13.7 & 14.42 & 18.23 & 18.23 & 0 & & & \\
\hline \multirow{3}{*}{10} & 66.7 & 0 & 3.84 & 5.24 & 6.5 & 41.84 & 36.23 & 5.61 & \multirow{3}{*}{31.6} & \multirow{3}{*}{172.6} & \multirow{3}{*}{6} \\
\hline & 120.3 & 0 & 4.27 & 9.45 & 10.37 & 26.41 & 24.3 & 2.11 & & & \\
\hline & 173.9 & 0 & 4.69 & 13.66 & 14.44 & 18.97 & 18.97 & 0 & & & \\
\hline \multirow{3}{*}{15} & 72.9 & 0 & 4.14 & 5.73 & 7.07 & 41.49 & 35.89 & 5.6 & \multirow{3}{*}{36.1} & \multirow{3}{*}{172.6} & \multirow{3}{*}{7} \\
\hline & 123.3 & 0 & 4.6 & 9.68 & 10.72 & 27.61 & 25.43 & 2.18 & & & \\
\hline & 173.7 & 0 & 5.06 & 13.64 & 14.55 & 20.37 & 20.37 & 0 & & & \\
\hline \multirow{3}{*}{20} & 81.7 & 0 & 4.51 & 6.42 & 7.85 & 40.65 & 35.09 & 5.56 & \multirow{3}{*}{39.7} & & \\
\hline & 127.6 & 0 & 5.01 & 10.02 & 11.21 & 28.81 & 26.56 & 2.25 & & 172.6 & 7.9 \\
\hline & 173.5 & 0 & 5.51 & 13.63 & 14.7 & 22.02 & 22.02 & 0 & & & \\
\hline & 89.7 & 0 & 4.89 & 7.05 & 8.58 & 40.32 & 34.77 & 5.55 & & & \\
\hline 25 & 131.6 & 0 & 5.44 & 10.33 & 11.68 & 30.05 & 27.74 & 2.31 & 42.8 & 172.6 & 8.8 \\
\hline & 173.4 & 0 & 5.98 & 13.62 & 14.88 & 23.7 & 23.7 & 0 & & & \\
\hline & & & & & Impelle & xit & & & & & \\
\hline & & & & & & imeter & & & & & \\
\hline $\begin{array}{c}\text { head, } \\
m\end{array}$ & $\mathrm{D} 2, \mathrm{~mm}$ & $B 2, m m$ & Lean, deg & $\begin{array}{l}\beta 2, \\
\text { deg }\end{array}$ & $W 2, \mathrm{~m} / \mathrm{s}$ & $\begin{array}{l}\alpha 2, \\
d e g\end{array}$ & $C 2, \mathrm{~m} / \mathrm{s}$ & Wslip/U2 & $\begin{array}{l}U 2, \\
\mathrm{~m} / \mathrm{s}\end{array}$ & $\mathrm{Cu}$ & $\mathrm{m} / \mathrm{s}$ \\
\hline 5 & 166 & 71.5 & 0 & 19.37 & 9.26 & 35.53 & 5.28 & 0.1 & 13.04 & & \\
\hline 10 & 201.3 & 68.6 & 0 & 16.84 & 9.11 & 20.42 & 7.57 & 0.15 & 15.81 & & \\
\hline 15 & 234.2 & 57.3 & 0 & 16.35 & 9.64 & 16.53 & 9.54 & 0.15 & 18.4 & & \\
\hline 20 & 264.5 & 47.8 & 0 & 16.12 & 10.39 & 14.95 & 11.17 & 0.15 & 20.78 & & \\
\hline 25 & 291.7 & 40.9 & 0 & 15.96 & 11.11 & 14.01 & 12.61 & 0.14 & 22.91 & & \\
\hline
\end{tabular}

Suction specific speed Nss characterizes intensity of the pump cavitation. The calculated values of Nss were 3.15. This indicates about good cavitation characteristic of the pump. The shaft power is increased in average by $5.2 \mathrm{~kW}$ at increasing of the pump head by $5 \mathrm{~m}$. The head coefficient $\psi$ has characteristic of energy transfer measure to fluid. Maximum difference of energy transfer to fluid was determined at the small values of the pump head. Changing determination of flow rate through the pump is carried out by the value of the flow coefficient. The flow coefficient is 0.239 at the pump head of $5 \mathrm{~m}$, the flow coefficient is 0.044 at the pump head of $25 \mathrm{~m}$. The stability factor $K s$ determines stable characteristic of the pump performance. Unstable characteristic of the pump performance is observed at head of 5 and $10 \mathrm{~m}(K s<$ 0.9). Net positive suction head required (NPSHr) for the pump performance provides reduction of noise and damage due to cavitation. NPSHr for all considered pumps is $3.64 \mathrm{~m}$. The diffusion ratio determines stable of head-flow curve. Maximum stable was determined at the diffusion ratio is 0.049 ; minimum stable was determined at the diffusion ratio is 0.121 .

The hub diameter $(D h)$ changes by $17.2 \mathrm{~mm}$ at increasing of the pump head by $20 \mathrm{~m}$ and the eye diameter $(D e)$ does not change $(172.6 \mathrm{~mm})$. The blades thickness of the impellers is increased in the range from 5 to $8.8 \mathrm{~mm}$ with increasing of the pump head. The values of the diameter $(D l)$, tangential velocity $(\mathrm{Cul})$, meridional velocity $(\mathrm{Cml})$, the blade speed $(U I)$, flow relative velocity $(W l)$, the blade angle $\left(\beta^{\prime} 1\right)$, relative flow angle $(\beta 1)$ and incidence (Inc) were calculated in the sections of the hub, the mean line and the shroud of the impellers. Incidence is calculated as difference of the angles of $\beta^{\prime} 1$ and $\beta 1$. Increasing of the $D l$ parameter at the hub and decreasing at the shroud is required with increasing of the pump head. Tangential velocity was not taken into account. Maximum meridional velocity is achieved at the impeller shroud. The blade speed of 


\begin{tabular}{|c|c|c|c|c|c|c|}
\hline \multirow{4}{*}{ Impact Factor: } & ISRA (India) & $=3.117$ & SIS (USA) & $=0.912$ & ICV (Poland) & $=6.630$ \\
\hline & ISI (Dubai, UAE & $=0.829$ & РИНЦ (Russia) & $=0.156$ & PIF (India) & $=1.940$ \\
\hline & GIF (Australia) & $=0.564$ & ESJI (KZ) & $=\mathbf{5 . 0 1 5}$ & IBI (India) & $=4.260$ \\
\hline & JIF & $=1.500$ & SJIF (Morocco) & $=5.667$ & & \\
\hline
\end{tabular}

the impeller increases in the sections of the hub and the mean line. Flow relative velocity of fluid at the impeller inlet varies from 6.13 to $14.88 \mathrm{~m} / \mathrm{s}$. Maximum changing of flow relative velocity of fluid is determined at the impeller hub. The blade angle of the impeller decreases at the hub, the relative flow angle increases at the mean line. The values of $\beta^{\prime} 1$ and $\beta 1$ are equal at the shroud.

The calculated parameters at the impeller trailing edge were written in the title Impeller exit (the table 3). The tip diameter (D2) changes in average by $31 \mathrm{~mm}$ at changing of the pump head by $5 \mathrm{~m}$. Maximum changing of the tip width of the impeller $(B 2)$ is observed at the pump head of $10-$ $20 \mathrm{~m}$. The calculated value of the lean angle was 0 degrees according to the results of five researches. The ratios of $U 1$ to tip speed at the impeller outlet (U2) are from 0.375 to 0.594 . Flow relative velocity at the impeller outlet (W2) is higher than $W 1$ at the hub and lower than at the mean line and the shroud. Relative flow angle $(\beta 2)$ at the impeller outlet is less than at the inlet. The absolute flow angle $(\alpha 2)$ is more than $\beta 2$ at the pump head values of $5-15 \mathrm{~m}$. Flow tangential velocity $(\mathrm{Cu} 2)$ at the impeller outlet increases in the range of $4.3-12.24 \mathrm{~m} / \mathrm{s}$, i.e. increases in 3 times at increasing of the pump head in 5 times. The values of flow absolute velocity $(C 2)$ at the impeller outlet were determined in the range of $5.28-12.61 \mathrm{~m} / \mathrm{s}$. The slip factor (Wslip/U2) characterizes the deviation degree of fluid flow from the impeller blade. The minimum degree of deviation of fluid flow is calculated at the pump head of $5 \mathrm{~m}$ and the corresponding geometry of the impeller blade.

\section{Conclusion}

Based on the performed analysis of the designed geometry of the impellers in conditions of changing of the pump head, it is possible to draw the following conclusions:

1. The impeller blades with the larger profile curvature should be made at the pump head of more than $20 \mathrm{~m}$.

2. Required performance of the pump (by conditions of the performed experiments) is provided by the mixed flow impellers at the pump head of up to $15 \mathrm{~m}$ and the radial impellers at the pump head of more than $20 \mathrm{~m}$.

3. The surfaces cavitation of the impellers occurs with the same intensity at the different pump heads and geometric characteristics of the blades.

4. Stable characteristic of the pump is observed at operation of the radial impellers with the calculated geometry. The calculated geometry of the impeller at the pump head of less than $10 \mathrm{~m}$ leads to unstable characteristic of the pump.

5. Calculated deviation of fluid flow from the impeller blade at the pump heads of $10-20 \mathrm{~m}$ is more by $5 \%$ than at the pump head of $5 \mathrm{~m}$.

\section{References:}

1. Baljé, O. (1981). Turbomachines - a guide to design, selection and theory. J. Wiley \& Sons, New York.

2. Smith, A. G. (1957). On the generation of the Streamwise Component of Vorticity for Flows in a Rotating Passage. Aeronautical Quartely, Vol. 8, 369-383.

3. Rusetskaya, G. V. (2005). Mathematical model of a liquid - discharge channel system of a radial impeller pump. Chemical and petroleum engineering, vol. 41, issue 7-8, 377-382.

4. Ben-Nun, R., Sheintuch, M., Kysela, B., Konfršt, J., \& Fořt, I. (2015). Semianalytical characterization of turbulence from radial impellers, with experimental and numerical validation. Aiche Journal, issue 4, vol. 61, $1413-1426$.

5. Van den Braembussche, R. A. (2006). Optimization of Radial Impeller Geometry. In Design and Analysis of High Speed Pumps (pp. 13-1 - 13-28). Educational Notes RTO-ENAVT-143, Paper 13. Neuilly-sur-Seine, France: RTO.
6. Harinck, J., Alsalihi, Z., Van Buijtenen, J. P., \& Van den Braembussche, R. A. (2005). Optimization of a 3D Radial Turbine by means of an improved Genetic Algorithm. Proceedings of the $5^{\text {th }}$ European Conference on Turbomachinery. (pp.1033-1042).

7. Lewis, R. I. (1996). Turbomachinery Performance Analysis. Elsevier Science \& Technology Books.

8. Chemezov, D. A. (2016). The parameters of the gas turbine blade when changing of the ratio of the output/input radius of the hub. ISJ Theoretical \& Applied Science, 02 (34), 75-85.

9. Epple, P., Miclea, M., Luschmann, C., Llic, C., \& Delgado, A. (2010). An extended analytical and numerical design method with applications of radial fans. Proceedings ASME International Mechanical Engineering Congress and Exposition. (pp.1119-1129).

10. Chemezov, D. A. (2015). Computer design and analysis of pressure distribution on the surface of the blade of the impeller radial turbine. ISJ Theoretical \& Applied Science, 01 (21), 1-6. 